INTER NATIONAL MONETARY FUND
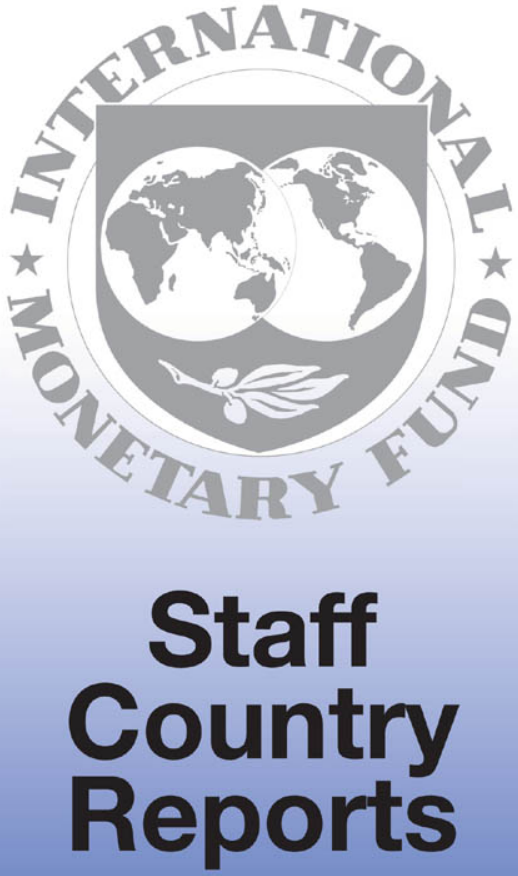


\section{Cambodia: 2004 Article IV Consultation-Staff Report; Public Information Notice and Press Release on the Executive Board Discussion; and Statement by the Executive Director for Cambodia}

Under Article IV of the IMF's Articles of Agreement, the IMF holds bilateral discussions with members, usually every year. In the context of the 2004 Article IV consultation with Cambodia, the following documents have been released and are included in this package:

- $\quad$ the staff report for the 2004 Article IV consultation, prepared by a staff team of the IMF, following discussions that ended on July 15, 2004, with the officials of Cambodia on economic developments and policies. Based on information available at the time of these discussions, the staff report was completed on August 11, 2004. The views expressed in the staff report are those of the staff team and do not necessarily reflect the views of the Executive Board of the IMF.

- $\quad$ a Public Information Notice (PIN) and Press Release summarizing the views of the Executive Board as expressed during its September 13, 2004 discussion of the staff report that concluded the Article IV consultation.

- $\quad$ a statement by the Executive Director for Cambodia.

The documents listed below have been or will be separately released.

Joint Staff Assessment of the Poverty Reduction Strategy Paper Progress Report

Poverty Reduction Strategy Paper Progress Report

Selected Issues Paper

Statistical Appendix

Ex Post Assessment of Longer-Term Program Engagement

The policy of publication of staff reports and other documents allows for the deletion of market-sensitive information.

To assist the IMF in evaluating the publication policy, reader comments are invited and may be sent by e-mail to publicationpolicy@imf.org.

Copies of this report are available to the public from

International Monetary Fund $\bullet$ Publication Services

$70019^{\text {th }}$ Street, N.W. • Washington, D.C. 20431

Telephone: (202) 623-7430 • Telefax: (202) 623-7201

E-mail: publications@imf.org •Internet: http://www.imf.org

Price: $\$ 15.00$ a copy

International Monetary Fund

Washington, D.C. 
INTERNATIONAL MONETARY FUND

CAMBODIA

\section{Staff Report for the 2004 Article IV Consultation}

Prepared by the Asia and Pacific Department

(In collaboration with other Departments)

Approved by David T. Coe and Donal Donovan

August 11, 2004

- The 2004 Article IV Consultation discussions were held in Phnom Penh during April 28May 11 and July 13-15. The team consisted of Messrs. Lee (Head, APD) and Nakamura (PDR), and Mmes. Abdelati, Muñoz (both APD), Kojo (FAD), and Rendak (LEG).

The mission was assisted by Mr. Hagemann (resident representative). Mr. Alowi (OED) attended the policy meetings. Mr. Valdivieso (APD), who led the work on the Ex-Post Assessment (EPA), discussed the EPA report with the authorities during the July 13-15 visit.

- The 2002 Article IV Consultation was completed on February 20, 2003, along with the sixth and final review of a three-year PRGF arrangement.

- Discussions on a new PRGF arrangement have been delayed by the political stalemate in the wake of the July 2003 national elections. Staff visited Phnom Penh in May and September 2003, and March 2004 to maintain the policy dialogue. Formal discussions on an arrangement could take place later this year.

- A power-sharing agreement, which was reached after eleven months of deadlock between the main political parties, paved the way to formation of a new government in mid-July. There were no changes to the economic team, nor are changes expected in economic policy. However, the number of political appointees in the government has doubled, which could compromise the functioning of the government.

- Cambodia accepted the obligations of Article VIII, Sections 2, 3, and 4 in January 2002, and has maintained an exchange system that is free of restrictions on the making of payments and transfers for current international transactions.

- Despite significant shortcomings in some areas, core data are generally adequate for surveillance purposes and are provided on a timely basis.

- The authorities intend to publish the staff report, the selected issues paper, and the Ex-Post Assessment report.

- This report was prepared by a team led by Mr. I. Lee. 


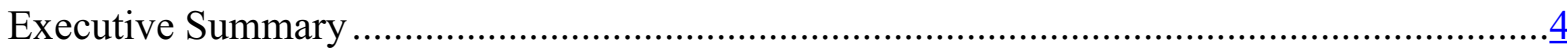

I. Background ….........................................................................................

II. Recent Economic Developments and Prospects for 2004 .................................... $\underline{8}$

III. Medium-term Prospects and Challenges...........................................................13

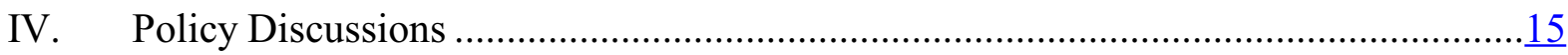

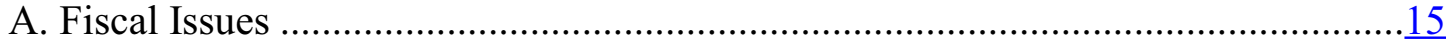

B. Monetary and Exchange Rate Policy....................................................... 18

C. Private Sector Regulatory Environment and Governance...................................19

D. Rural Development and Aid Allocation......................................................... $\frac{20}{22}$

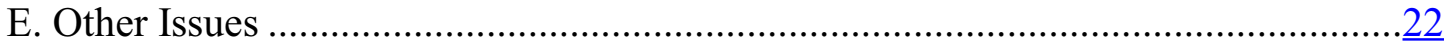

F. Ex-Post Assessment of Longer-Term Program Engagement ............................... $\underline{23}$

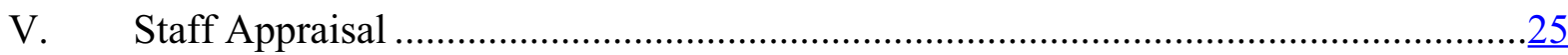

\section{Text Boxes}

1. Poverty in Cambodia.......................................................................................

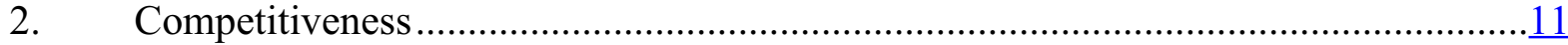

3. Impediments to Agricultural Growth ............................................................ 12

4. Legal and Judicial Reform .....................................................................

Figures

1. Selected Economic Indicators, January 1997_-June 2004 ....................................28

2. Performance Indicators, 1998-2004 ................................................................29

Tables

1. Selected Economic Indicators, 1999-2004 ......................................................... $\underline{30}$

2. Balance of Payments, 2000-09 ..........................................................................

3. Monetary Survey, 2000-04.............................................................................

4a. General Government Operations, 2000-04 …................................................

4b. General Government Operations, 2000-04 ..........................................................

5. Medium-Term Macroeconomic Framework, 2002-09 .......................................... $\underline{35}$

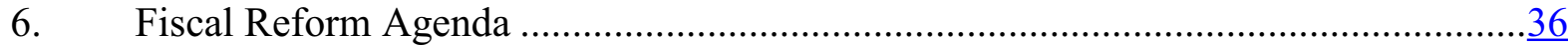

7. Schedule for Enacting Laws for WTO Conformity .......................................... 37 


\section{Annexes}

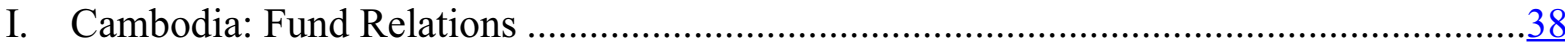

II. Cambodia: Debt Sustainability........................................................................... 40

III. Cambodia: World Bank Policy Dialogue and Its Relation with the IMF...................... 48

IV. Relations with the Asian Development Bank ................................................... 54

V. Cambodia —Statistical Issues.......................................................................55

VI. Summary of Technical Assistance Provided by the Fund, 1999-June 2004.................. $\underline{58}$ 


\section{EXECUTIVE SUMMARY}

- Macroeconomic performance in the past few years was generally good, reflecting both favorable external developments and prudent fiscal policy. Exports soared following a bilateral trade agreement with the U.S., and large aid inflows helped finance domestic investment and spurred construction activities. Prudent fiscal policy has been key to ensuring price stability.

- These favorable developments, however, have masked underlying structural weaknesses. Competitiveness has deteriorated on account of poor governance - in part due to lack of progress in legal and judicial reform — which exacerbated uncertainty in the business environment, while rudimentary infrastructure and high wages have kept operating costs high. Slow growth in agriculture, where most of the poor make their living, has pushed Cambodia further from meeting the MDGs.

- Non-agricultural growth slowed to 3.2 percent in 2003 due to the SARS-related drop in tourism and election-related uncertainties. Overall GDP growth, however, was robust mainly because of a strong rebound in agricultural production. Prices remained stable reflecting low trading partner inflation and prudent fiscal policy, although some of the earlier gains in fiscal revenue collection were lost in the election year. The pace of reforms stalled in the run-up and aftermath of the July 2003 elections. The 2004 budget law, along with a range of legislation needed to complete WTO accession, still awaits parliament approval.

- Growth is expected to slow in 2004-05. While tourism is rebounding, agricultural growth is expected to be lower than the exceptionally high growth of the previous year. A further slowdown, possibly to below 2 percent GDP growth, is expected as Cambodia's garment industry will be exposed to direct competition from China following the elimination of the quota system in January 2005.

- A refocus of economic policies is needed to achieve the NPRS targets. In the medium term, improving competitiveness will require a more forceful approach to addressing the impediments to private sector activities, particularly the regulatory environment and governance problems. In the long run, agricultural reforms through improved use of land and a redirection of foreign aid toward promoting agricultural growth will be essential to reduce poverty and generate employment to absorb the growing labor force.

- Without stronger political resolve, medium-term economic growth is unlikely to be sufficiently strong to reduce poverty. Additional revenue mobilization is necessary to meet social spending needs and maintain fiscal sustainability. Effective use of revenue and aid resources and improved service delivery hinge on hitherto resisted comprehensive civil service reforms. Legal and judicial reform, which has been on the government's reform agenda for years, are critical to institute a transparent and accountable economic system. 


\section{BACKGROUND}

1. Economic growth in the 1990s was robust, albeit from an exceptionally low base given the damage from the 20-year civil war. UN-sponsored elections in 1993 yielded a coalition government but internal tensions persisted, undermining the rebuilding process. Elections in 1998 produced a more durable coalition government that oversaw a period of generally positive economic performance. More recently, tensions between the former coalition partners in the wake of the July 2003 elections delayed the formation of a new government with sufficient parliamentary support until mid-July 2004. ${ }^{1}$ Economic reforms largely came to a halt during the eleven-month stalemate.

2. Large aid inflows and the boom in the garment and tourism sectors have helped Cambodia develop a formal sector around the main urban areas. The rural areas, however, where most of the poor live as subsistence farmers with highly volatile incomes, were left behind. The average household expenditure in the rural area has declined from 33 percent of that in Phnom Penh in 1993/94 to 28 percent in 1999, and is estimated to have declined further to about 25 percent in 2002. Moreover, the minimum wage, which is high relative to average wages and increasingly being applied to all industries in the formal sector, reduced employment opportunities for the growing

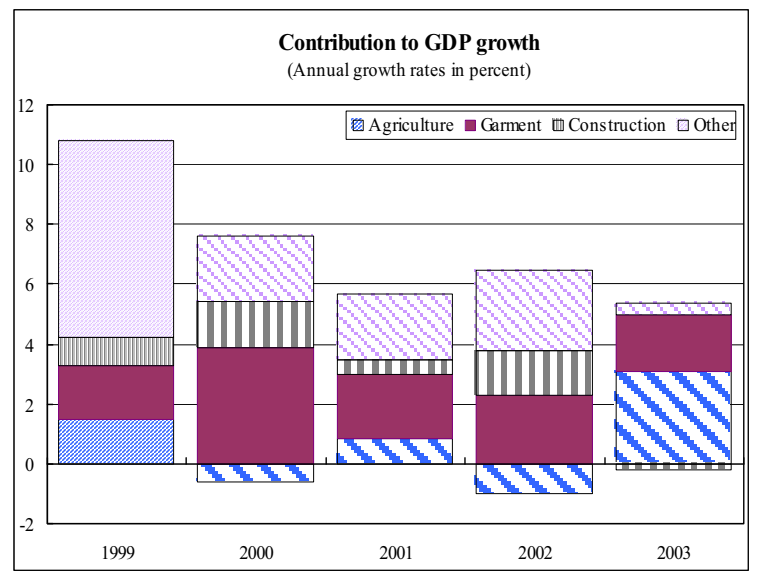
labor force.

3. Accordingly, only limited progress has been made in alleviating poverty since the beginning of reconstruction efforts. Cambodia remains one of the poorest countries in the region with 36 percent of the population in poverty as of 1999. Moreover, Cambodia is seriously off-track from the MDGs in several aspects (Box 1).

\section{Cambodia's development program was supported by a three-year PRGF} arrangement for SDR 58.5 million (67 percent of quota), approved on October 22, 1999. The sixth and final review was completed in February 2003, after which a disbursement of SDR 8.4 million raised total Fund credit and loans outstanding to Cambodia to SDR 70 million (80 percent of quota). The National Poverty Reduction Strategy Paper (NPRS), together with a Fund-Bank joint staff assessment, was also endorsed by the Fund

\footnotetext{
${ }^{1}$ Hun Sen's party solidified its seats in the July 2003 national elections but not by enough to rule. A power-sharing agreement with one of the main opposition parties in June 2004 paved the way to the formation of a new coalition government in mid-July 2004.
} 


\section{Box 1. Poverty in Cambodia}

Cambodia is one of the poorest countries in the world, with a per capita gross national income less than half of the East Asia and Pacific average. Based on the World Bank Atlas Method, Cambodia's per capita gross national income is US\$300, the lowest in the East Asia region with the exception of Myanmar. It has some of the worst human development indicators in the world, ranking $130^{\text {th }}$ out of 173 countries, with a national poverty level of 36 percent. The population is deprived of basic physical and institutional infrastructure as a result of decades of political and social instability until the early 1990s.

Despite steady growth during the last decade, poverty and inequality have remained stubbornly high. Thirty-six percent of the population had incomes below the poverty line of $\$ 0.40-0.63$ per day in 1999 , only marginally below the 39 percent in $1994 .{ }^{1}$ In addition, the GINI index of 40 percent implies a high level of inequality. The 20 percent of households with the lowest (per capita) income only receive 7.5 percent of the total income, while the highest quintile receives 46 percent of total income.
Poverty Indicators

Poverty Headcount Ratio

$\begin{array}{lll}\text { Cambodia } & \mathbf{3 6} & (1999) \\ \text { Lao PDR } & 39 & (1998) \\ \text { Malaysia } & 16 & (1989) \\ \text { Thailand } & 13 & (1992) \\ \text { Vietnam } & 29 & (2002)\end{array}$

GNI Per Capita, Atlas Method (US\$)

\begin{tabular}{lrl} 
Cambodia & $\mathbf{3 0 0}$ & $(2002)$ \\
Lao PDR & 310 & $(2002)$ \\
Malaysia & 3,540 & $(2002)$ \\
Thailand & 2,000 & $(2002)$ \\
Vietnam & 430 & $(2002)$ \\
\hline
\end{tabular}

Source: World Development Indicators, 2004.

\section{Cambodia is off-track in pursuing the Millennium Development Goals:}

- Food security is lagging. At 36 percent, the proportion of people suffering from hunger is far from the 2015

Rural Social Conditions, 2001 target of 19.5 percent. Poverty is worse in rural areas. The high proportion of under-weight children under age 5 persists owing to inadequate food intake, lack of health care, and poor sanitation.

\begin{tabular}{lr}
\hline Forest area (\% of land area, 2000) & 52.9 \\
Arable land (\% of land area) & 21.0 \\
Irrigated land (\% of cropland) & 7.1 \\
Permanent cropland (\% of land area) & 0.6 \\
Rural population (\% of total population) & 82.6 \\
Poverty headcount (1999) & \\
$\quad$ Rural & 39.2 \\
Urban & 17.7 \\
Access to sanitation facilities (\% of population) & \\
$\quad$ Rural & 10.0 \\
Urban & 56.0 \\
Access to safe driking water (\% of population) & \\
$\quad$ Rural & 26.0 \\
Urban & 54.0 \\
\hline
\end{tabular}

Source: World Development Indicators 2004.
- Child mortality has increased over the past ten years, particularly post-neonatal mortality. The main causes have been diarrheal diseases, acute respiratory infections, and vaccine-preventable diseases, particularly measles where the coverage rate of immunization is only 59 percent, well-below the 2015 target of 90 percent. Despite progress, the maternal mortality rate remains extremely high at around 437 per 100,000 live births.

- Cambodia could achieve primary education for all by 2015, but is unlikely to reach its secondary education and gender equality targets. At 20.3 percent in 2001, the youth illiteracy rate was much higher than the 3 percent average in East Asia and the Pacific.

Health and sanitary conditions are very poor: only 30 percent of the population has access to safe drinking water and only 17 percent has access to sanitation facilities. The conditions are especially poor in rural areas where only 10 percent has access to sanitation. More resources are needed to improve basic household amenities, especially in remote areas. Given the rural concentration of the poor, meaningful poverty reduction will require more broadbased growth based on agriculture diversification and higher agricultural productivity.

${ }^{1}$ Using the poverty line of US $\$ 1$ per day (based on purchasing power parity exchange rates), the poverty headcount ratio for 1999 was 41.5 . 
Box 1 (continued). Cambodia: Selected Poverty Indicators

\begin{tabular}{|c|c|c|c|c|c|}
\hline & 1985-89 & $1990-94$ & 1995-01 & Latest data & $\begin{array}{r}2015 \\
\text { MDG } \\
\text { Target }\end{array}$ \\
\hline \multicolumn{6}{|l|}{ Goal 1 - Eradicate extreme poverty and hunger } \\
\hline Poverty Headcount ${ }^{1}$ & $\ldots$ & 39.0 & 36.0 & $35.9(1999)$ & 19.5 \\
\hline Undernourished people (as \% of total population) & $\ldots$ & 41.0 & 36.0 & $36.0(2000)$ & 20.5 \\
\hline Under-weight children under 5 & $\ldots$ & 52.4 & 50.3 & $45.0(2001)$ & 26.2 \\
\hline Share of poorest 20 percent in national income & $\ldots$ & 7.3 & 7.2 & 7.5 (1999) & 11 \\
\hline \multicolumn{6}{|l|}{ Goal 2 - Achieve universal primary education } \\
\hline Net school enrollment rate, primary & $\ldots$ & $\ldots$ & 93.0 & $95.4(2000)$ & 100 \\
\hline Net school enrollment rate, secondary & $\ldots$ & $\ldots$ & 17.4 & $16.7(2000)$ & 100 \\
\hline Youth illiteracy rate ( $\%$ of people ages $15-24)$ & 28.5 & 25.6 & 22.3 & $20.3(2001)$ & 0 \\
\hline \multicolumn{6}{|l|}{ Goal 3 - Promote gender equality and empower women } \\
\hline Ratio of girls to boys in primary education (\%) & $\ldots$ & $\ldots$ & 90 & $90(2001)$ & $100^{2}$ \\
\hline Ratio of girls to boys in secondary education (\%) & $\ldots$ & $\ldots$ & 60 & $60(2001)$ & $100^{2}$ \\
\hline Ratio of girls to boys in tertiary education (\%) & $\ldots$ & $\ldots$ & 40 & $40(2001)$ & 100 \\
\hline \multicolumn{6}{|l|}{ Goal 4 - Reduce child mortality } \\
\hline Under 5 mortality rate (per 1,000 live births) & 152.5 & 115.0 & 131.0 & $138.0(2002)$ & 38.3 \\
\hline Immunization, measles ( $\%$ of children under 12 months) & 41.2 & 38.4 & 57.0 & $52.0(2002)$ & 90 \\
\hline \multicolumn{6}{|l|}{ Goal 5 - Improve maternal health } \\
\hline Maternal mortality ratio (per 100,000 live births) & $\ldots$ & 900.0 & 513.5 & $437.0(2000)$ & 250 \\
\hline Births attended by skilled health staff ( $\%$ of total) & $\ldots$ & 34.0 & 34.4 & $31.8(2000)$ & 80 \\
\hline Contraceptive prevalence ( $\%$ of women ages $15-49$ ) & $\ldots$ & $\ldots$ & 19.6 & $23.8(2000)$ & 100 \\
\hline \multicolumn{6}{|l|}{ Goal 6 - Combat HIV/AIDS, malaria, and other diseases } \\
\hline HIV prevalence ratio among adults ( $15-49$ years) $(\%)$ & $\ldots$ & 1.0 & 3.3 & $2.8(2000)$ & 1.8 \\
\hline \multicolumn{6}{|l|}{ Goal 7 - Ensure environmental sustainability } \\
\hline Access to sanitation facilities ( $\%$ of population) & $\ldots$ & $\ldots$ & 17.0 & $17.0(2000)$ & \\
\hline Access to safe drinking water ( $\%$ of population) & $\ldots$ & $\ldots$ & 30.0 & $30.0(2000)$ & \\
\hline \multicolumn{6}{|l|}{ Goal 8 - Develop a global partnership for development } \\
\hline Fixed line and mobile telephones (per 1,000 people) & 0.3 & 0.8 & 8.5 & $30.1(2002)$ & \\
\hline Personal computers (per 1,000 people) & $\ldots$ & $\ldots$ & 1.0 & $2.0(2002)$ & \\
\hline \multicolumn{6}{|l|}{ Memorandum Items: } \\
\hline GDP per capita (U.S. dollars) & 237.6 & 256.5 & 287.6 & $296.3(2002)$ & \\
\hline GDP growth & 7.7 & 5.8 & 6.4 & $5.5(2002)$ & \\
\hline Population growth & 3.2 & 3.1 & 2.2 & $2.6(2002)$ & \\
\hline Aid (\% of GDP) & $\ldots$ & 13.2 & 13.3 & $14.1(2002)$ & \\
\hline Investment (\% of GDP) & $\ldots$ & 11.5 & 16.0 & $22.2(2002)$ & \\
\hline GINI index ${ }^{3}$ & $\ldots$ & $\ldots$ & 40.4 & $40.4(1997)$ & \\
\hline \multicolumn{6}{|c|}{$\begin{array}{l}\text { Source: World Development Indicators, 2003; Human Development Report, 2004; United Nations Development Goals } \\
\text { (Cambodia 2001); and IMF staff estimates. }\end{array}$} \\
\hline
\end{tabular}


and Bank Boards in February 2003. The National Bank of Cambodia (NBC) prepares its audited financial statements in accordance with International Financial Reporting Standards, as required under the Fund's safeguards policy. An IMF safeguards assessment mission in January 2004 found that progress has been made and proposed measures to strengthen the remaining weaknesses of NBC's control framework.

\section{During the 2002 Article IV Consultation, Directors welcomed progress under the}

PRGF. However, they noted the widespread poverty, narrow production base, low revenue to GDP, and pervasive governance concerns. They underscored the need to strengthen government capacity and promote broad-based economic growth through investment and a vibrant private sector. The accompanying Ex-post Assessment report provides a detailed account of the Fund's contribution to Cambodia's recent economic growth.

\section{ReCEnt EConomic DeVelopments And Prospects for 2004}

6. Macroeconomic performance in the past few years was generally good. With the advent of political stability in 1999, private sector activities, reportedly also in the informal sector, flourished in urban areas. Annual real GDP growth averaged 6-7 percent, reflecting both favorable external developments and prudent macroeconomic policies (Table 1). In particular:

- Exports soared following a bilateral trade agreement with the United States that effectively reduced the average U.S. tariff rate for garments produced in Cambodia from 50-70 percent to $10-20$ percent. The 1996 trade agreement attracted a large number of foreign investors, which contributed to a sharp increase in garment exports to the U.S. from nearly zero in 1995 to $\$ 500$ million in 1999 and to more than \$1 billion in 2003, which is about 70 percent of total garment exports (Table 2). The benefit to the domestic economy, however, was limited as almost all non-labor inputs were imported.

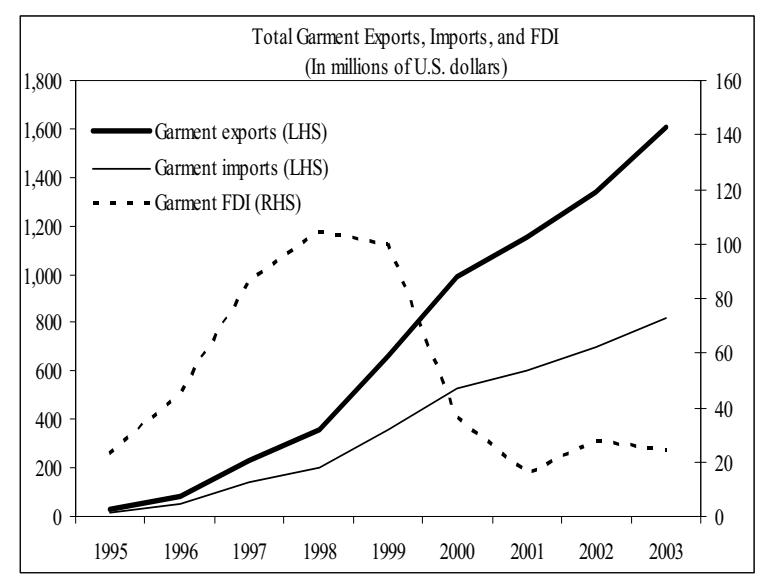


- $\quad$ Large aid inflows, which averaged 12 percent of GDP, helped finance domestic investment and fueled construction activities. About half of the inflows were grants in the form of donor-financed projects and technical assistance, all of which were outside the budget. Aid inflows were used to improve health and education, rebuild physical infrastructure, and strengthen economic and social institutions.

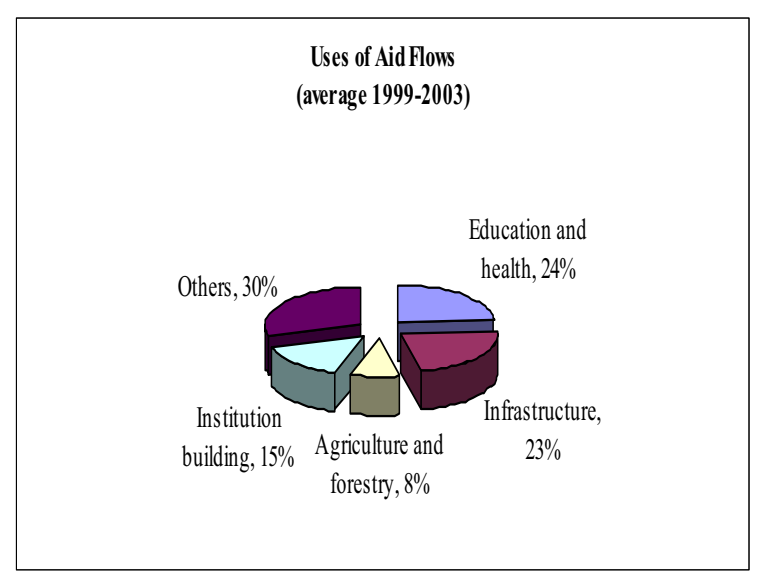

- $\quad$ Prudent fiscal policy has been key to ensuring price stability in Cambodia's highly dollarized economy. As much as 95 percent of total liquidity, including estimated U.S. dollars in circulation, is in dollars. With few monetary policy instruments, the task of ensuring that aggregate demand does not become a source of inflation necessarily falls to fiscal policy. This task has been made easier in recent years because of low inflation in U.S. dollar terms in trading partners.

7. Fiscal revenue improved from 8.1 percent of GDP in 1998 to 11.2 percent in 2002 owing in part to strengthened tax and customs administration. The latter was supported by an extensive technical assistance program under the Technical Cooperation Action Plan (TCAP). Nevertheless, total revenue remains lowabout 11 percent of GDP compared with an average of 16 percent of GDP in neighboring low-income countriesseverely constraining priority spending. For example, civil service wages remain well below private sector wages, and roads and other public facilities are poorly maintained. Although recourse to domestic bank financing of the fiscal deficit was largely averted, arrears to domestic suppliers have accumulated.

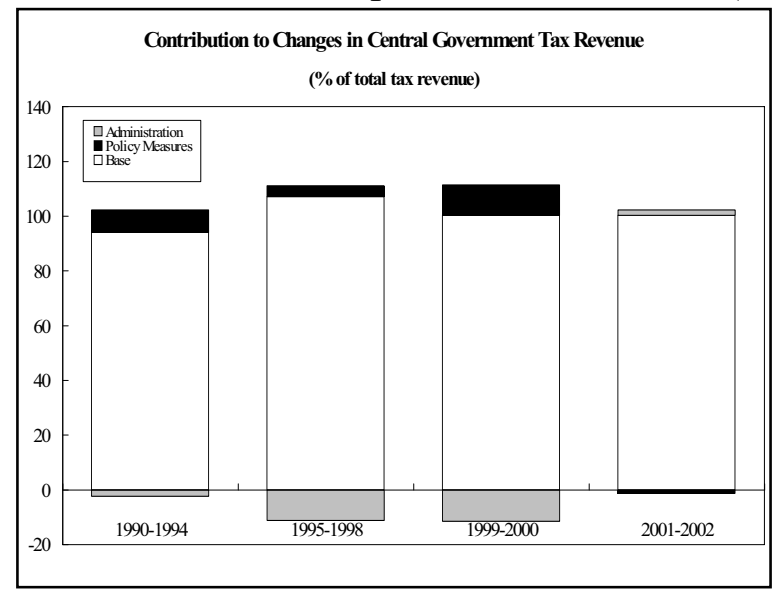

8. More recently, nonagricultural growth slowed to 3.2 percent in 2003 due to the SARS-related drop in tourism and election-related uncertainties. However, overall GDP still grew by 5.2 percent, mainly because a lower Mekong river level—due to lower rain fall— exposed a larger area of arable land that allowed a strong rebound in agricultural production. Revenue collection was disappointing, partly reflecting low nonagricultural growth, but more 
importantly due to greater tax evasion and smuggling by importers. ${ }^{2}$ Election-related spending during the year helped to boost consumption, which, however, required a sharp curtailment of non-priority expenditure toward the end of the year, especially given the poor revenue collection. The external current account deficit (excluding official transfers) widened by $1 \frac{1}{4}$ percent to 101/4 percent of GDP due to buoyant merchandise imports, lower tourism receipts, and higher petroleum prices. The vulnerability of the deposit base of the banking system was apparent during the July elections when foreign currency deposits declined by 20 percent in a matter of 1-2 weeks. They recovered, however, later in the year (Table 3).

9. Only modest progress on structural reforms has been made since 1999. Basic institutions were set up and various laws ranging from commercial contracts to accounting were adopted. A Financial Institutions Law was passed that provided the legal basis for successful bank re-licensing. However, progress has been particularly slow in civil service and judicial reform due to political resistance. The pace of structural reforms slowed across all sectors in the run-up to, and aftermath of, the July 2003 election. The 2004 budget and a range of legislation needed to complete WTO accession still await approval by the National Assembly.

10. More importantly, the reconstruction efforts have not yet been able to establish a strong foundation for sustainable growth, even in urban areas. In particular, structural weaknesses, complicated by deeply rooted governance problems, remain in the following three inter-related areas:

- An underlying deterioration of competitiveness has been masked by favorable external developments. Poor public administration and weak governance — partly due to slow progress in legal and judicial reform - have exacerbated uncertainty in the business environment and allowed the rich to set their own rules. In addition, embryonic and poorly maintained infrastructure and high wages have kept operating costs high (Box 2). ${ }^{3}$

- Agricultural development has stagnated due to limited access to arable land and markets (Box 3). Slow growth in agriculture has pushed Cambodia further away from meeting the MDGs and reduced its capacity to absorb the growing number of entrants to the labor market over the medium term.

\footnotetext{
${ }^{2}$ Tax collection by the customs department declined from an average 15 percent of retained nongarment imports in 2001-02 to below 13 percent in 2003 (notwithstanding the modest decline in the unweighted average tariff, which is estimated to have negligible revenue implications).

${ }^{3}$ See Chapter 2, "Implications of Removal of Quotas in 2005," in the accompanying Selected Issues paper, which shows Cambodia to be one of the most vulnerable countries among Asian low-income countries to the garment quota elimination.
} 


\section{Box 2. Competitiveness}

Cambodia's garment exports have risen rapidly since the late 1990s, mainly reflecting two factors. The first is the 1996 bilateral trade agreement with the United States that substantially reduced the effective tariff rate on garments produced in Cambodia. The second factor is the large economic rent for Cambodian exporters to the U.S. market reflecting the U.S. quotas imposed on Chinese garment exporters. The underlying weaknesses of Cambodia's competitiveness can be gleaned from two key observations.

\begin{tabular}{|c|c|c|c|c|c|c|c|}
\hline & $\begin{array}{l}\text { Total } \\
\text { Garment } \\
\text { Exports } \\
\text { to the } \\
\text { U.S. }\end{array}$ & $\begin{array}{c}\text { Exports } \\
\text { Subject } \\
\text { to } \\
\text { Quota }\end{array}$ & $\begin{array}{l}\text { Cotton } \\
\text { Trousers }\end{array}$ & $\begin{array}{c}\text { Cotton } \\
\text { Knit } \\
\text { Shirt }\end{array}$ & $\begin{array}{l}\text { M-MF } \\
\text { Knit } \\
\text { Shirts }\end{array}$ & $\begin{array}{l}\text { Non- } \\
\text { Knit } \\
\text { Shirts }\end{array}$ & Coats \\
\hline \multicolumn{8}{|l|}{ Exports to the U.S. by category } \\
\hline Quota utilization ratio, in percent & & 63 & 93 & 81 & 50 & 65 & 79 \\
\hline Exports, in million US\$ & 1,123 & 711 & 386 & 182 & 39 & 40 & 29 \\
\hline
\end{tabular}

Sources: Ministry of Commerce of Cambodia and U.S. Department of Commerce, Office of Textiles and Apparel.

- Cambodia is unable to fully utilize its allocated quota. Most of Cambodia's garment exports are in categories that are subject to U.S. quotas on imports from China. However, Cambodia's garment exports are below their quota in the U.S. market, and almost negligible in non-U.S. markets such as in Japan, while Chinese products dominate the market in the same categories.

- $\quad$ Non-garment exports have remained flat in U.S. dollar terms. The business community estimates that a 15-30 percent cost reduction is required for Cambodia to remain competitive relative to China. Recent proposals to move garment manufacturers to export processing zones will have limited impact since Cambodia already provides extensive tax incentives.

\section{There are many reasons for Cambodia's weak competitiveness.}

Competitiveness is impeded by poor infrastructure, corruption, and red tape. According to the World Bank's recent Investment Climate Survey and Value Chain Analysis, the average cost of starting a business is estimated to be as high as 553 percent of per capita income, compared with 30 percent in Vietnam and 7 percent in Thailand. The "bribe tax" is estimated at $51 / 4$ percent of sales in manufacturing, more than double the rate in Bangladesh, Pakistan, and China. Moreover, it takes an average of 18 days to obtain export customs clearance in Cambodia, compared with 11 days in India

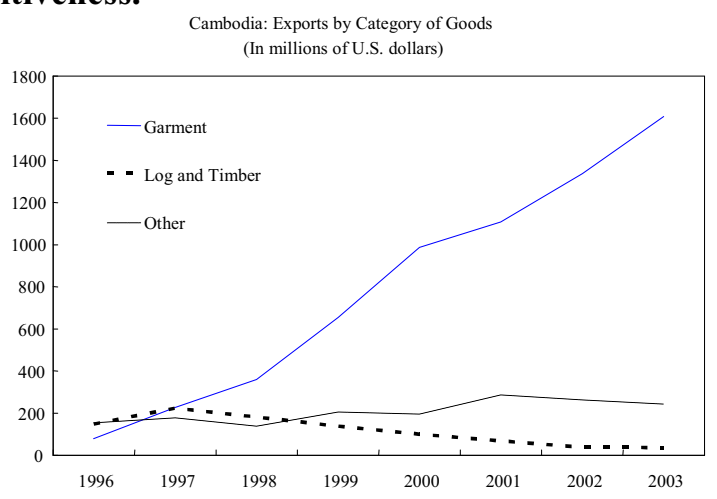
and 7 in China.

High labor cost has been another factor. At a minimum wage of $\$ 45$ a month and an average of $\$ 61$ a month in the garment sector, Cambodia's wages are higher than in several neighboring countries, including Vietnam, India, and Sri Lanka. Moreover, foreign investors are subject to a 100 percent wage premium for night shifts, are restricted from operating on weekends or any of the 22 national holidays to meet temporary demand surges, and face frequent labor strikes. 


\section{Box 3. Impediments to Agricultural Growth}

\begin{abstract}
About 80 percent of the poor depend on agriculture for their livelihood. Agriculture contributes 40 percent to GDP and accounts for 70 percent of employment. During 1994-2003, the sector grew at an annual average of less than 4 percent, contributing very little to employment growth. The average rice yield, estimated at 2.1 tons per hectare in 2001, is the lowest in Southeast Asia, reflecting in part low labor productivity. For example, a worker in Cambodia produces $44 \mathrm{~kg}$ of rice compared with $62 \mathrm{~kg}$ in Thailand.
\end{abstract}

Pro-poor growth will depend on addressing key constraints faced by the rural economy in agriculture:

Lack of access to arable land
GDP Growth

\begin{tabular}{|c|c|c|c|c|}
\hline & \multicolumn{2}{|c|}{ Share in } & \multirow{2}{*}{$\begin{array}{c}\text { Growth }^{1} \\
1994-2003 \\
\end{array}$} & \multirow{2}{*}{$\begin{array}{l}\text { Poverty } \\
\text { Incidence }\end{array}$} \\
\hline & GDP & Employment & & \\
\hline \multicolumn{4}{|c|}{ (in 2000) } & (in 1999) \\
\hline Agriculture & 0.38 & 0.70 & 3.8 & 78.9 \\
\hline Industry & 0.24 & 0.10 & 15.0 & 3.8 \\
\hline Services & 0.35 & 0.20 & 4.9 & 11.0 \\
\hline Total & 1.00 & 1.00 & 6.6 & 93.7 \\
\hline
\end{tabular}

Sources: NPC Statistics, MOP: A Poverty Profile of Cambodia 1999, and Cambodia Socio-Economic Survey 1999

${ }^{1}$ Average annual growth rates.

- $\quad$ Lack of land availability. Only 1 percent of land area is used for permanent cropland and only 7 percent of this is irrigated. Cultivated land rose gradually from 1.4 million hectares in the mid-1980s to about 2.4 million hectares in the late 1990s, and has not increased since. Furthermore, most of the new land from de-mining ( 0.1 million hectares) and forest clearance (2.5 million hectares) has reportedly been allocated to the rich, who do not use the land for cultivation. This is partly corroborated by NGO reports that claim the government has approved 0.8 million hectares as land concessions in the past few years. However, official data show no expansion in cultivated land.

- Lack of property rights. Only 10 percent of farmers have formal title to their farming land. With no property rights, most farmers are hesitant to engage in long-term investment and have no access to collateralized lending.

\section{Limited access to economic opportunities}

- Inadequate rural roads and poor road maintenance impede commercialization. Of the $12,323 \mathrm{~km}$ of the existing road network, only 16.20 percent is paved. In comparison, Thailand has 98 percent of its road network paved, Malaysia 76 percent, and Vietnam 25 percent. There are no secondary roads and tertiary roads often feed directly into the primary network. Moreover, the rail system is in need of major rehabilitation.

- Weak marketing systems. Only small scale informal trading of surplus rice occurs with Vietnam and Thailand. Cambodian farmers have weak bargaining power due to limited information on market prices. In addition, lack of warehouses contributes to huge price swings between post- and pre-harvest seasons (close to 100 percent sometimes), damaging poor farmers. The absence of agricultural associations and cooperatives also slows agricultural development.

- Lack of modern farming techniques and advanced technology. Farmers use traditional seeds that produce low crop yields. Moreover, even though good quality fertilizers are imported from Thailand, these are diluted by middleman before reaching the farmers.

- Limited access to formal financial services. The state-owned Rural Development Bank acts as a wholesale bank, mainly in lending to NGO microfinance institutions. So far six micro-finance institutions have been licensed and the largest (Acleda) has recently obtained a commercial bank license. None of the other commercial banks lend to farm households. It is estimated that only 15 percent of the rural population has access to financial institutions. As a result, farmers are under-capitalized and have no means of adopting new technology, improving seeds, or using fertilizers.

- $\quad$ Barriers to public health. Due in large part to the low pay of public sector health workers, the public must pay fees to obtain free public health services. This limits farmers access to health care and their ability to earn income.

\section{Limited access to forestry and fisheries}

Forest and fisheries resources, which were previously a source of supplementary food and income to farmers, have become increasingly difficult to access. Recent changes in natural resource management policies have left vast areas of the country (30 to 40 percent of total area) with unclear management arrangements. 


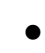

Government capacity remains severely constrained by lack of human capital and entrenched governance problems. The quality of the civil service remains poor, and fiscal revenue, currently at 10.4 percent of GDP, is hardly enough to meet basic priority spending needs (Table 4).

11. The outlook for economic growth in 2004 is tinted by weaker prospects for agricultural production. The Avian flu earlier in the year, the smaller fish catch due to the lower Mekong river level, and agricultural production that is unlikely to be much higher than last year's bumper crop indicate weaker output growth. While non-agricultural growth is expected to rebound strongly due to a recovery in tourism, overall GDP would most likely increase by $4-4 \frac{1}{2}$ percent. The impact of still-high petroleum product prices is expected to widen the external current account deficit by another $1 / 2$ percent of GDP. Inflation is also likely to inch up reflecting price developments in trading partner countries.

\section{Medium-term Prospects And Challenges}

\section{Urgent reform in the agricultural sector is essential to achieve the NPRS}

objective of reducing poverty. As a small open economy with ample unused arable land and a large unskilled labor force, agriculture is widely recognized to be Cambodia's comparative advantage. Promoting agriculture is the best strategy to secure a key source of growth that could help absorb a part of the expected increase in the labor force, address poverty more directly, and provide a more rapid expansion of domestic market for manufactured products. A more dynamic agricultural sector may also encourage foreign investment, which has been weak, partly because the population of 13 million does not provide a sufficiently large domestic market.

\section{Cambodia can no longer rely on the garment sector as the engine of growth.}

Efforts should focus on improving competitiveness to dampen the impact from the expected decline in garment exports and encourage diversification of its export base. This is particularly urgent because the elimination of the quota system in January 2005 will expose Cambodian exporters to direct competition from China, where production costs are estimated to be 15 to 30 percent lower than in Cambodia. It will take some time before Cambodia's exports could recover, even if all identified reforms are undertaken. The value of garment exports could decline by 12 percent in 2005, which might reduce GDP growth to below 2 percent. A depreciation of the exchange rate is likely to have only a limited impact on 
competitiveness because most costs, including wages, are denominated in U.S. dollars. ${ }^{4}$ The overall impact of the quota removal on the balance of payments, however, would be modest as garment-related inputs, almost all of which are imported, and profit remittances would also drop. Cambodia could earn some time if the U.S. takes recourse in either the so called "product specific" safeguard against Chinese imports, available until 2013, or the special textiles safeguard, which expires in 2008. However, it would be highly risky for the government to formulate its economic strategy on the uncertain assumption that the U.S. will adopt either of these two options. Furthermore, additional tariff reduction by the U.S. or relaxation of rule of origin requirements by the EU and Canada would have only a marginally favorable impact.

\section{Even under the best case scenario, which assumes improved governance and reduced costs, growth would only reach the annual NPRS target of 6-6 $1 / 2$ percent}

by 2009 (Table 5). Under this scenario, public debt, which was 75 percent of GDP at the end of 2003, is expected to be sustainable. Assuming that Cambodia reaches a debt rescheduling

\begin{tabular}{|c|c|c|c|c|c|c|c|c|}
\hline \multicolumn{9}{|c|}{$\begin{array}{l}\text { Cambodia: Baseline and Non-adjustment Scenarios } \\
\text { (In percent of GDP, unless otherwise indicated) }\end{array}$} \\
\hline & 2002 & 2003 & 2004 & 2005 & 2006 & 2007 & 2008 & 2009 \\
\hline \multicolumn{9}{|l|}{ Baseline scenario } \\
\hline Real GDP growth (percent change) & 5.5 & 5.2 & 4.3 & 1.9 & 4.3 & 5.5 & 5.9 & 6.1 \\
\hline Of which: Garment (percent change) & 21.0 & 15.0 & 12.0 & -12.0 & -1.0 & 5.8 & 7.2 & 7.2 \\
\hline Of which: Agriculture (percent change) & -2.7 & 9.2 & 0.4 & 3.2 & 3.7 & 3.8 & 3.9 & 4.2 \\
\hline Of which: Other (percent change) & 7.9 & 0.4 & 4.9 & 4.9 & 6.0 & 6.4 & 6.8 & 6.9 \\
\hline Government revenue & 11.2 & 10.4 & 11.9 & 12.3 & 12.9 & 13.3 & 13.6 & 14.0 \\
\hline Current Expenditure, of which & 10.1 & 11.0 & 10.7 & 11.2 & 11.9 & 11.9 & 12.2 & 12.2 \\
\hline Wages & 3.7 & 3.7 & 3.7 & 3.8 & 4.0 & 4.2 & 4.5 & 4.7 \\
\hline Other & 6.3 & 7.3 & 7.0 & 7.4 & 7.9 & 7.7 & 7.7 & 7.5 \\
\hline Of which: Social spending (excluding wages) & 2.0 & 1.8 & 2.1 & 2.2 & 2.3 & 2.4 & 2.5 & 2.7 \\
\hline Primary deficit & 3.6 & 4.3 & 3.2 & 3.1 & 3.1 & 2.7 & 2.5 & 2.1 \\
\hline Garment export (in US\$ million) & 1,338 & 1,607 & 1,794 & 1,587 & 1,590 & 1,699 & 1,839 & 1,991 \\
\hline Current account balance, excluding official transfers (in US\$ million) & -359 & -429 & -489 & -545 & -565 & -567 & -566 & -567 \\
\hline Gross international reserves (in US\$ million) & 663 & 737 & 782 & 804 & 838 & 886 & 935 & 1,021 \\
\hline \multicolumn{9}{|l|}{ Non-adjustment scenario } \\
\hline Real GDP growth (percent change) & 5.5 & 5.2 & 4.3 & 0.9 & 2.7 & 3.1 & 3.4 & 3.7 \\
\hline Of which: Garment (percent change) & 21.0 & 15.0 & 12.0 & -15.0 & -5.0 & -2.0 & 0.0 & 3.0 \\
\hline Of which: Agriculture (percent change) & -2.7 & 9.2 & 0.4 & 3.2 & 3.3 & 3.1 & 2.7 & 2.7 \\
\hline Of which: Other (percent change) & 7.9 & 0.4 & 4.9 & 4.0 & 4.0 & 4.2 & 4.5 & 4.5 \\
\hline Government revenue & 11.2 & 10.4 & 11.1 & 10.9 & 10.9 & 10.9 & 11.0 & 11.0 \\
\hline Current Expenditure, of which & 10.1 & 11.0 & 10.3 & 10.0 & 9.9 & 9.9 & 9.9 & 9.9 \\
\hline Wages & 3.7 & 3.7 & 3.6 & 3.5 & 3.5 & 3.5 & 3.5 & 3.5 \\
\hline Other & 6.3 & 7.3 & 6.7 & 6.5 & 6.4 & 6.4 & 6.4 & 6.4 \\
\hline Of which: Social spending (excluding wages) & 2.0 & 1.8 & 1.9 & 1.9 & 1.9 & 1.9 & 1.9 & 1.9 \\
\hline Primary deficit & 3.6 & 4.3 & 3.7 & 3.3 & 3.1 & 3.1 & 2.8 & 2.8 \\
\hline Garment export (in US\$ million) & 1,338 & 1,607 & 1,794 & 1,579 & 1,516 & 1,490 & 1,495 & 1,545 \\
\hline Current account balance, excluding official transfers (in US\$ million) & -359 & -429 & -489 & -621 & -639 & -647 & -599 & -575 \\
\hline Gross international reserves (in US\$ million) & 663 & 737 & 782 & 728 & 688 & 656 & 672 & 749 \\
\hline
\end{tabular}

${ }^{4}$ Chapter 4, "Pro-Poor Exchange Rate Policy: a Poverty and Social Impact Analysis," in the Selected Issues paper discusses the potential impact on the poor from different policy responses to the quota elimination. 
agreement with the Russian Federation and the United States on comparable terms to the 1995 Paris Club agreement, Cambodia's net present value (NPV) of public debt at the end of 2004 would be reduced to 33 percent of GDP. ${ }^{5}$ However, the NPV of public debt would still represent around 235 percent of total revenue (280 percent excluding grants); a significant strengthening of the revenue effort would be needed to reduce this below 200 percent after 2013 (Annex II).

\section{Failure to press ahead more resolutely with reform will limit growth to}

2-4 percent annually in the medium term. A new government that lacks a strong commitment to improve governance is likely to fail to improve the business environment, which will make a recovery from the negative shock of the quota elimination highly unlikely; and with lower revenue collection, the government will be unable to meet even priority spending needs. Moreover, long-run growth will be jeopardized if agricultural sector reforms are not implemented. In this non-adjustment scenario, the NPV of public debt will reach about 230 to 250 percent of fiscal revenue, threatening fiscal sustainability. While the economy is not likely to experience a financial or balance of payment crisis, the lack of reform will slow progress toward poverty alleviation, which in turn could lead to social unrest.

\section{Policy Discussions}

16. The authorities were more sanguine than the mission about short- and mediumterm economic prospects. They considered that their current efforts to reduce red tape, together with close adherence to core labor standards - which they believe will support demand for made-in-Cambodia garments - would be adequate to ensure only a modest slow down in growth after the quota phase out. Moreover, they have recently received new investment proposals in the garment sector from Vietnam, where the U.S. quota will remain beyond early 2005 until Vietnam accedes to the WTO. They agreed that agricultural development was important to reduce poverty and raise long-term growth, and to consider, in consultation with donors, the possibility of reorienting aid flows.

\section{A. Fiscal Issues}

17. Supported by robust first quarter results, the government was cautiously optimistic that fiscal revenue collection, which declined in 2003, would recover in 2004. They indicated that the low collection by the customs department partly reflected delayed payments of taxes. Moreover, the government has also started implementing some of the

\footnotetext{
${ }^{5}$ If reaching an agreement is further delayed, Cambodia's external cash flow position will improve in the near term to the extent that the current interest charges on the stock of debt (which are largely in arrears) are negligible.
} 
fiscal measures announced late last year. ${ }^{6}$ The mission, however, argued that additional tax policy measures equivalent to 0.8 percent of annual GDP during the second half of 2004 would be needed to meet their revenue target (inclusive of measures announced last December). The authorities expressed doubts about their ability to do this during the remainder of the year, but agreed that there was substantial scope for additional revenue from strengthened anti-smuggling efforts. Even if the revenue target is met and recurrent spending contained, domesticfinanced capital spending will be substantially compressed because of

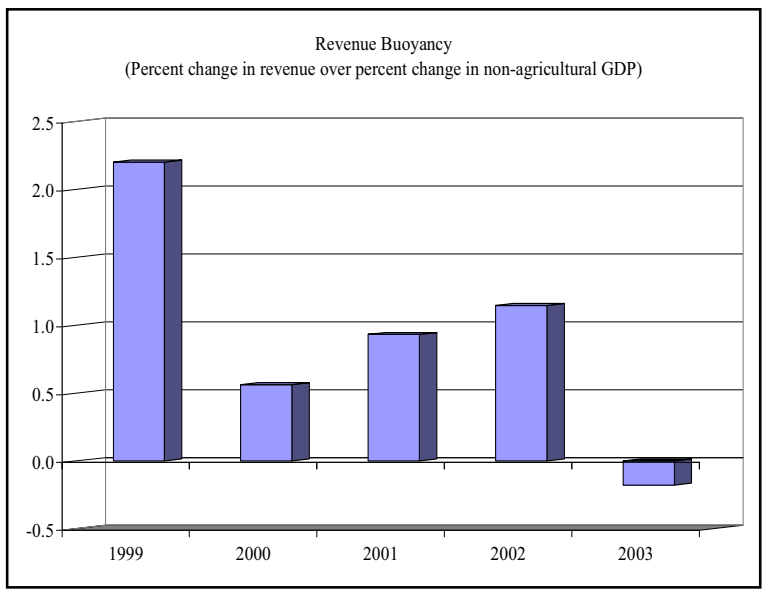
compensation payments to Thailand, higher interest payments following possible closure of their debt rescheduling negotiations, and settlement of a portion of the stock of arrears to domestic suppliers. ${ }^{7}$

\section{To meet the NPRS targets, total cumulative revenue measures equivalent to} about $2 \frac{1}{2}$ percent of GDP will be needed over 2004-09. This requirement would rise further if foreign financing were to decline from current levels. The authorities agreed with the need to introduce additional revenue measures, but indicated that they would not want to pre-commit to any specific measure at this stage. They assured the mission, however, that they would continue to avoid recourse to domestic bank financing, which has helped contain riel inflation. On the spending side, a continued tight lid on non-wage and non-social spending will allow a modest increase in the wage bill, from an average salary of $\$ 34$ a month in 2003 (compared with an average garment worker's wage of $\$ 60$ a month) to $\$ 80$ a month by 2008 , while improving the primary balance to a level that is consistent with a sustainable fiscal path by 2007 .

\section{The authorities agreed that computerization of the revenue departments will} help better capitalize on the technical assistance provided so far by reducing paperwork and keeping track of collections, a key to reducing corruption. The authorities are currently

\footnotetext{
${ }^{6}$ The measures include subjecting all telecom charges and airline tickets to a 10 percent excise, and introducing a specific tax on kerosene, bicycles, and air-conditioners at 10 percent. The full-year revenue impact of these measures could be as high as 0.35 percent of GDP. However, faced with strong resistance, the authorities are not yet fully enforcing these measures. Moreover, the announced increase in the ad-valorem tax on beer from 20 percent to 30 percent has been put on hold.
}

${ }^{7}$ While comprehensive data are not available, the mission estimated total domestic arrears at end-2003 to be around 3 percent of GDP, including unsettled outstanding operations from previous years and payment orders during 2003 in excess of cash released. 
reviewing least cost options, but one that could be easily expanded to other departments in future. In addition, they will continue to collect arrears (receivables) to institute a tax-paying culture. They were also receptive to the mission's recommendation to restructure the organizational structure of the Tax Department to one based on taxpayer services, education, and self-assessment. With regard to customs reforms, they agreed that passage of the Law on Customs, which the new government should re-submit to parliament without further delays, is crucial to strengthen enforcement and reduce smuggling. The authorities indicated that they would, in collaboration with other law enforcement agencies, also monitor closely large urban distribution centers where smuggled products are alleged to be sold.

20. The authorities are now more cautious in awarding government contracts. Most of the Build-Operate-Transfer contracts in recent years were awarded through direct negotiations that resulted in actual payments to the Treasury, through either profit sharing or taxes, that were well below expectations. ${ }^{8}$ While noncommittal, the authorities agreed about the need for the National Audit Authority to audit the operations of existing contract holders with significant fiscal implications to verify compliance with the terms of the contracts. For new contracts, the World Bank's proposed overhaul of the procurement and concession legislation, which stresses competitive bidding, is expected to help address part of the problem in the medium term. Recently, the Ministry of Economy and Finance (MEF) stopped awarding a power project to a private company and asked the IFIs to provide an assessment of the proposal. In response, the World Bank and the AsDB will identify the least cost national power development plan, against which the current and any future projects can be compared.

21. The public expenditure management reform agenda remains large (Table 6). Reform of the Treasury slowed in 2003: about two thirds of line ministries still do not provide timely reports of their transactions to the Treasury, and foreign currency units within the MEF manage their accounts separately. Partly reflecting a revenue shortfall, the Cash Management Committee was unable to smooth out the government's spending commitments during 2003, resulting in yet another late-year bunching of spending and earmarking of next year's tax receipts. The authorities noted, however, that disbursements under the Priority Action Plan for social spending had accelerated, and the backlog was expected to be fully cleared by early 2005. To better coordinate and monitor public expenditure management (PEM) reform, the MEF has established a reform committee, which will also serve as the counterpart to a donor technical working group under a Sector-Wide-Approach to PEM reform. The authorities were also committed to improving the effectiveness of public spending once lessons are learned from the World Bank's ongoing expenditure tracking study.

\section{The government will complete the ongoing studies before making a decision about overhauling the structure of the civil service and wages. Public employment, at}

\footnotetext{
${ }^{8}$ The mission estimated that foregone revenue from three key contracts signed in recent years could be as much as $\$ 15$ million a year.
} 
some $2 \frac{1}{2}$ percent of the total population, and an associated wage bill of less than 4 percent of GDP are within international norms. However, civil service wages are well below that of the formal private sector, and the wage structure is highly compressed. The authorities indicated that they are reluctant to downsize the civil service because of social concerns, especially when unemployment was rising. However, they now expect to complete key studies, which have been substantially delayed, within the next few months, which are critical inputs to formulating a comprehensive civil service reform strategy in consultation with the World Bank. The studies include functional reviews to determine appropriate institutional arrangements, organization, processes, and staffing of government functions; and labor market analyses to identify adequate remuneration. The government was, however, less committal on demobilization, which had stalled since the first phase was completed in late 2002.

\section{B. Monetary and Exchange Rate Policy}

\section{The central bank will continue to intervene in the foreign exchange market to} stabilize excessive fluctuation of the exchange rate. Domestic currency cash injected by government spending is normally retained in circulation as the transaction demand for riel continues to rise with economic growth. Exchange rate instability typically arises when government spending accelerates and the central bank is slow to absorb the excess supply in riel. Mindful of the shallowness of the market and that exchange rate policy has only limited effects on competitiveness, the mission supported the NBC's policy to stabilize "riel" inflation at a low level by maintaining a broadly stable exchange rate. At the same time, the authorities should not preclude an exchange rate adjustment if there are fundamental changes in underlying market conditions exerting pressure in the foreign exchange market.

\section{The mission agreed with the NBC that Cambodia would benefit from de-}

dollarizing the economy in the long run. In addition to the loss of seigniorage, the lack of monetary policy independence and the central bank's inability to act as a lender of last resort could eventually threaten financial stability. Moreover, although the United States now accounts for 25 percent of Cambodia's gross external trade, this is expected to decline after the elimination of the quota system. Hence, the potential benefits of lower transactions cost from certainty about the value of the riel vis-à-vis the U.S. dollar will be more limited. Dedollarization initiatives, such as requiring that all government transactions be conducted in domestic currency, could also be considered. But forceful administrative measures or political uncertainty could immediately translate into capital flight, as there is still lack of confidence in riel.

25. The authorities acknowledged that commercial banks have played only a limited role in facilitating investment finance. While successful bank restructuring during 2000-02 contributed to financial deepening, bank loans in percent of GDP remain well below those in other countries in the region. Even then, the NBC agreed to closely monitor credit expansion, especially since banks' credit risk assessment capacity is weak, legal infrastructure including the enforceability of financial contracts is not in place, and reliable borrower information is not available. In this regard, passage of the Negotiable Instruments and Payment Transactions Law, the Secured Transaction Law, the Insolvency Law, and the Securities and Exchange 
Law, is expected to reduce payment system risks and provide a legal basis for collateralbased lending. Early completion of the implementation of the new chart of accounts and the accounting law will provide banks better information on potential borrowers.

\section{Private Sector Regulatory Environment and Governance}

26. Private sector activities are deterred by the high costs of inputs and governance problems, as confirmed in a recent World Bank analysis. ${ }^{9}$ The high input cost associated with poor infrastructure and human capital needs to be addressed. In the short run, the authorities will consider revisiting the provisions for overtime, nightshift, and holiday pay - while upholding core labor standards - to reduce labor costs. The mission emphasized that greater wage flexibility is also needed. Moreover, the minimum wage was segmenting the labor market, hindering growth in employment. On governance, the authorities agreed that establishing an independent and well functioning judiciary within a transparent

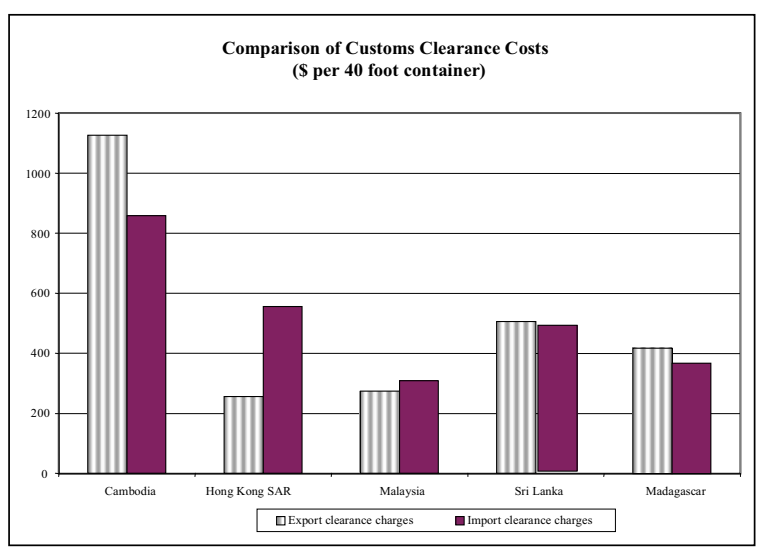
legal framework is a basic prerequisite to creating a conducive business environment. The mission noted that, additionally, a strong political commitment is required to urgently address administrative impediments to investment and the high informal fees, not only to help the garment sector recover quickly, but also to promote export diversification.

\section{Only in recent years has work begun to strengthen the legal and judicial system} in conjunction with WTO accession. Most of the laws, however, are still in draft form. Once the accession package is adopted by the National Assembly, Cambodia will become, along with Nepal, one of the first low-income countries to join the WTO. ${ }^{10}$ Benefits are expected to be wide-ranging as accession requires adoption of 46 pieces of legislation over the next several years, ranging from judicial reform to trade related property rights. But equal effort needs to be placed on proper implementation of the legislation. In response to criticism from some NGOs that Cambodia's WTO accession would expose the country to open competition for which it is not ready, government officials indicated that Cambodia was already fully open, and that WTO accession would provide an opportunity to put in place an orderly environment in which Cambodia will be able to better compete.

\footnotetext{
9 "Seizing the Global Opportunity: Investment Climate Assessment and Reform Strategy," June 2003.

${ }^{10}$ In view of the political impasse, the WTO has granted an extension to September 2004, by which time the accession package needs to be adopted by parliament (Table 7).
} 
28. The government has recently increased salaries of judges and established the Royal School of Judges and Prosecutors. Some progress has also been made by the working groups tasked with producing an action plan to implement the Strategy for Legal and Judicial Reform. Donors were resistant, however, to providing more assistance noting that not much had been done even though the legal and juridical reform has been on the government's agenda for the past 10 years. While donor assistance would undoubtedly help, there are measures that could be implemented in the short term for which, above all, political will is required. These include adopting the law on the status of judges and prosecutors, embarking on the implementation of a long pending reform of the Supreme Council of Magistracy, and establishing a commercial court (Box 4). The authorities cautioned, however, that judiciary reform, especially reform of the Supreme Council of Magistracy, would likely be delayed as it was a sensitive issue and needed to honor an understanding that was reached between the political parties as part of their power-sharing agreement.

\section{Rural Development and Aid Allocation}

\section{The authorities acknowledged that progress in agricultural development has}

been slow. The mission questioned why cultivated land area had not increased since the late 1990s even though there is ample unused land. In this regard, the mission recommended auditing the already awarded land concessions, and reviewing the transfer process of ownership of de-mined and deforested land. ${ }^{11}$ Combined with the limited land use and low agricultural productivity, population growth is estimated to have worsened poverty. The authorities noted that progress was already being made in distributing land to farmers, and did not agree that poverty was on the rise. They were, however, concerned about demographic developments that would see large inflows of young people enter the labor market in coming years.

30. Lack of roads and information on prices limits the ability of, or incentive for, small scale farmers to sell their produce in competitive markets. Moreover, the absence of a clear land registration system has weakened incentives to improve land productivity by building irrigation systems. The authorities indicated that they would consider helping farmers set up agricultural associations and cooperatives that would, as a group, have better access to market information and a stronger bargaining position. Such associations could also improve farmers' access to financial resources. On the latter, the

${ }^{11}$ Lack of enforcement of property rights is reported to have favored those with power, rather than small farmers, in land disputes. 


\section{Box 4. Legal and Judicial Reform}

The existing legal framework and judicial institutions are weak, and their reform is substantially behind schedule, constituting a major impediment to private sector growth and foreign investment.

\section{Legal and judicial system}

Cambodia's legal system is based on civil law. The Constitution adopted in 1993 provides for the separation of powers, and establishes the judiciary as an independent institution. The Supreme Council of Magistracy is charged with helping the King to ensure judicial independence and to discipline judges and prosecutors.

Cambodia's judicial institutions comprise provincial and municipal courts, which adjudicate the majority of civil and commercial disputes, Appeals Court, Supreme Court, and military courts. At present, there are no specialized commercial courts or independent arbitration with the exception of the recently established labor arbitration council, whose decisions are neither mandatory nor subject to enforcement.

There are currently 195 judges and prosecutors (also referred to as "magistrates"). Judges have little expertise or experience to handle commercial disputes, and are widely perceived to lack independence from political influence and vested interests. Enforcement of court decisions is unpredictable and costly.

\section{Recent developments in legal and judicial reform}

While the legal and judicial reform has been on the government's agenda for the past 10 years, work has only recently begun on drafting new legislation in conjunction with preparation for the WTO accession. Most of the laws are still in draft form.

On the positive side, salaries of judges were raised in 2003 from $\$ 25-30$ a month to $\$ 200-400$ a month, and the Royal School of Judges and Prosecutors was established. The School enrolled the first 55 students in November 2003, for graduation in 24 months. In June 2003, the government adopted the Strategy for Legal and Judicial Reform. Working groups have been tasked to produce an action plan that will prioritize reform measures by mid-2004 and be used to solicit assistance from the international community.

\section{Where do we go from here?}

In the medium term Cambodia's accession to the WTO is expected to strengthen the legal system. Commitment of the authorities will be required to embark on reforming the judiciary. While Cambodia will require significant donor assistance, some measures that require little or no such assistance can and should be implemented in the short term. These include:

- $\quad$ Adopting the law on the status of judges and prosecutors that would establish an appointment process and the terms and conditions of service, including a code of conduct.

- Taking concrete steps to ensure the independence and the transparency of the operation of the Supreme Council of the Magistracy, to enable it to fulfill its functions set forth in the Constitution.

- $\quad$ Establishing a commercial court that will specialize in commercial dispute resolution. A law on the commercial court is currently being prepared and is expected to be passed in 2005 .

- $\quad$ Passing an anti-corruption law that establishes an effective framework for investigation and prosecution of corruption offences and provides for declaration of income and assets by government officials; and preparing the implementing regulations.

- $\quad$ Publishing all court decisions and creating a repository of all laws in Khmer and in English. 
mission endorsed the NBC's strategy to reduce lending rates in rural areas through increased competition among lending institutions. Donors and the IFIs are providing support in a few areas: the AsDB is providing assistance in commercialization of agriculture, diversification of crops, and land management, while the World Bank is focusing on land concessions and titling.

31. The authorities saw a need to review, together with donors, the current allocation of foreign aid flows. Although weak administrative capacity may have required that about 50 percent of all aid flows be used for technical cooperation, a reallocation may be needed to more directly address poverty and boost long-term growth. The enormous investment needs of the agricultural sector argue for greater allocation of resources for building infrastructure that could support irrigation systems and roads to markets.

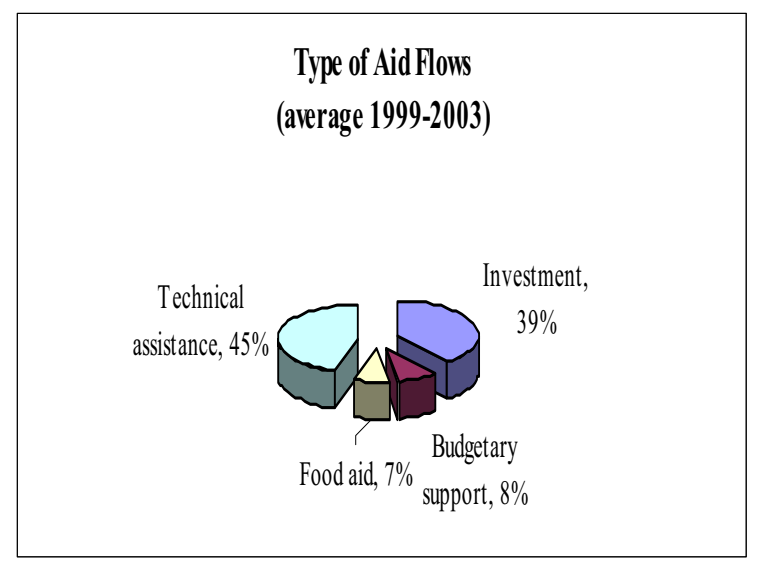

\section{Unsustainable logging has destroyed a valuable source of income and}

contributed to soil erosion. Although the ban on logging remains in place, monitoring of log transportation and other forest crime prevention schemes remains weak. The authorities reiterated their commitment to retain the ban on logging until sustainable forest management plans are put in place. A plan for community based forestry to safeguard the livelihood of local communities is also being considered. In particular, more forceful action is required by the government to incidents reported by the Société Générale de Surveillance, the new independent forestry monitoring firm.

\section{E. Other Issues}

33. The authorities are continuing their dialogue with the Russian Federation and the United States to reach agreement on debt rescheduling. The latest proposal from the Russian Federation involves an upfront cash payment and substantial debt cancellation. The Cambodian authorities have indicated that they are seeking further clarification on the Russian proposal, and intend to intensify negotiation with the United States.

\section{In accordance with Cambodia's commitment under ASEAN, its tariff lines were} recently reclassified to the ASEAN Harmonized Tariff Nomenclature (AHTN). The authorities confirmed that even after the conversion to AHTN, their unweighted average tariff remained unchanged at 15 percent - Cambodia's average tariff was reduced from 16.5 percent in 2003 to 15 percent under the old tariff nomenclature. 
35. Cambodia's statistical framework is being upgraded but substantial weaknesses remain. The authorities agreed on the need to start relying more on their own resources and training to strengthen technical capacities. However, the revenue situation makes it unlikely that any meaningful amount of resources would be allocated to statistics from the budget.

36. A draft comprehensive anti-money laundering law is being prepared with the assistance of LEG and MFD. An interministerial working group was charged with this task, headed by the NBC. The Prime Minister has also instructed that a Financial Investigation Unit be set up at the NBC, indicating his commitment to anti-money laundering.

\section{F. Ex-Post Assessment of Longer-Term Program Engagement}

37. Cambodia's longer term program engagement was reviewed in the context of the Ex-Post Assessment report discussions. ${ }^{12}$ The authorities welcomed the draft EPA report as a useful review and foundation for future reform plans. They noted that the EPA gave appropriate consideration to the adverse initial conditions, provided a good description of developments under Fund-supported programs, and presented a balanced assessment of the strengths and weaknesses of the policies pursued during the period under review. They agreed with the main finding of the report that, despite important progress achieved in many areas, poverty remained pervasive and governance problems widespread. They also agreed with the key elements of the strategy proposed in the EPA for future engagement with the Fund, and reiterated their desire to start discussions on a new PRGF soon. However, the authorities had a number of observations.

- The report could have emphasized more the challenges faced in the transition to a market economy. In particular, the challenges posed by people's attitude toward the role of the government - they had grown to depend too much on government actions during the central planning period-and the problems faced in rebuilding and reestablishing trust in, and credibility of, key institutions. Deepening confidence is key for future development.

- As regards the thrust of macroeconomic policies, the authorities agreed that it will be critical to maintain stability to achieve high growth and reduce poverty. In line with the EPA recommendations, they believe fiscal policy will continue to play a central role. They will continue in their efforts to enhance revenue and strengthen expenditure control. The authorities also agreed not to resist fundamental pressures on the exchange rate, but noted that the impact of a flexible exchange rate may be very limited as long as the market remains shallow and dollarization continues to be

12 The accompanying EPA report was prepared by a separate team led by Mr. Valdivieso (APD). 
widespread. That said, they agreed with the steps outlined in the report to achieve dedollarization.

- $\quad$ The authorities agreed that pervasiveness of poverty was a serious problem but warned against an unqualified comparison of indicators across countries, particularly given the differences in data quality and methodologies used in calculation. They reiterated their intention to gear their policy efforts toward meeting the NPRS goals, especially by expediting structural reforms that would enhance the impact of growth on poverty reduction.

- $\quad$ The authorities agreed that much remains to be done in the governance area and reiterated their determination to address it forcefully. They noted, however, that governance problems were not exclusive to the public sector. In this regard, they thought the report could have also discussed the extent of transparency and accountability problems outside the government sector, including in the corporate sector and the NGOs.

- $\quad$ The authorities thought the report covered well long-term issues and policy requirements relating to agricultural development; their focus has been on measures with a short-term impact, such as, for example, enhancing marketing channels and institutionalizing micro-finance activities in rural areas.

- On external financial assistance, the authorities agreed that there was a need to enhance the informational database to analyze aid effectiveness, and noted that actual aid inflows may be less than recorded because they include donors' overhead costs in their respective countries. They considered that aid in the form of technical cooperation was adequate given their depleted human capital, but noted that donors would have helped promote greater ownership by using more local staff, which would have saved scarce financial resources. Finally, they pointed to several ongoing efforts at enhancing donor coordination, for example, the progress achieved so far in developing a framework to enhance the public sector's financial management in consultation with the Bank, Fund, and other donors.

38. The authorities requested that the Fund continue to provide policy advice, more focused technical assistance, and financial support. They reiterated their desire to start discussions on an economic program to be supported by a PRGF arrangement. In addition to helping to strengthen Cambodia's official international reserve position and contain possible adverse effects from the forthcoming elimination of the garment quota, an arrangement with the Fund would help underpin a framework for donor coordination and encourage domestic reform efforts within the government. While underscoring their responsibility for ensuring that technical assistance is used effectively by choosing the right counterparts, they emphasized the importance of training local trainers to ensure that the transmission of skills proceeds more smoothly. 


\section{Staff Appraisal}

39. Cambodia has come a long way in rebuilding its economy from the ruins of decades-long civil strife. However, poverty alleviation remains a challenge that the recent, narrow based growth has not been able to address. Nurturing the agricultural sector, where Cambodia has a natural comparative advantage, becomes all the more urgent as Cambodia will no longer be able to rely on the garment sector after the elimination of the quota system in early 2005. With most of the poor living in rural areas, agricultural development is the only way to address poverty directly.

40. Limited access to arable land is a key impediment to agricultural growth. The staff urges the government to focus more on land issues, including auditing the already awarded economic concessions, reviewing the transfers of ownership of de-mined and deforested land, and speeding up land registration. It is also important that the government review, together with donors, the current allocation of foreign aid flows with a view to refocusing it on agricultural development.

41. Cambodia also needs to intensify its efforts to promote growth in other sectors, for which it will need to attract foreign investment. It is recognized, however, that reducing the high input costs associated with poor infrastructure and human capital, and establishing a sound regulatory environment, can only be achieved in the long run. There is considerable scope for improvements in the short run, however, by cutting cumbersome red tape and the high informal fees, and by allowing greater wage flexibility. These are especially important in a dollarized environment where the exchange rate can not be used to improve competitiveness.

42. The staff urges that judicial reform be accelerated to address governance problems that are deeply rooted in all aspect of economic activities. The weakness of the judiciary is evident: there have been no reported cases of prosecution for any business-related activities or corruption since reconstruction efforts began in the early 1990s. The staff looks forward to the adoption of the anti-corruption law and the law on the status of judges and prosecutors, which would establish an appointment process and the terms and conditions of service, and to the establishment of a commercial court that will specialize in commercial dispute resolution. WTO accession will be helpful in putting in place a legal framework given the many laws required for membership. The staff notes, however, that the benefits of adopting the WTO accession package will only be realized if the laws are properly and forcefully enforced.

43. The staff commends the authorities for maintaining macroeconomic stability that has helped Cambodia to achieve robust growth in the recent past. Fiscal policy will need to continue to play a central role, and for this, it will be important to enhance revenue and strengthen expenditure control in the period ahead. 
44. Attaining the government's medium-term fiscal objectives hinges critically on the success of additional revenue mobilization. To meet the 2004 revenue target, additional tax policy measures equivalent to 0.8 percent of GDP (inclusive of measures announced last December) will be needed in the second half of this year. Over the medium term, attaining the NPRS targets of higher social spending and rural infrastructure development will require a serious commitment by the government to improve revenue collection, through both additional tax policy measures and strengthening tax and customs administration. In this respect, computerization in the revenue departments and the passage of the Law on Customs will be crucial to strengthen enforcement capabilities.

45. The agenda for fiscal management reform is large. The establishment of the MEF reform committee promises a new opportunity to promote ownership and internalization of technical assistance. On awarding contracts, the staff recommends that the National Audit Authority audit the operations of existing contract holders with significant fiscal implications to verify compliance with the terms of the contracts. The audit reports should be made available to the public.

46. To improve the effectiveness of the government, overhauling the civil service and its wage structure is essential. Early completion of the ongoing studies, which have been substantially delayed, will be critical to prepare a comprehensive civil service reform strategy in consultation with the World Bank.

47. The staff supports the central bank's policy of intervening in the foreign exchange market to stabilize excessive fluctuations of the exchange rate. Mindful that the exchange rate policy does not have much impact on improving competitiveness, the staff suggests maintaining a broadly stable exchange rate, barring fundamental changes in market conditions.

48. The staff agrees with the NBC that Cambodia would benefit from de-dollarizing the economy in the long run. De-dollarization initiatives, such as requiring that all government transactions be conducted in domestic currency and issuing a larger denomination note, could be considered. But forceful and abrupt administrative measures or political uncertainty could immediately translate into capital flight.

49. Strengthening the legal infrastructure is key to promoting sound financial intermediation of banks. The staff looks forward to an early passage of the Negotiable Instruments and Payment Transactions Law, the Secured Transaction Law, the Insolvency Law, and the Securities and Exchange Law, all of which are needed to reduce payment system risks and to ensure a legal basis for collateral-based lending. Early completion of the implementation of the new chart of accounts and the accounting law will provide banks better information on potential borrowers.

50. Failure to push the reform agenda forward, especially measures to improve the business environment and accelerate agricultural reforms, will jeopardize attaining the 
NPRS targets. In particular, governance related reforms, especially that of the judiciary, will require a strong political commitment. Further delays could lead to reduced donor financing and threaten fiscal sustainability.

51. The staff welcomes continued dialogue with the United States and the Russian Federation to seek ways to complete the debt rescheduling negotiation, and looks forward to an early completion.

52. Cambodia's statistical framework is being upgraded but substantial weaknesses remain. In the coming years, there is a need to rely more on domestic resources and training to strengthen technical capacities. If donor financing is lacking, this may require a shift of resources within the current budget.

53. The mission welcomes progress made in the preparation of a new comprehensive anti-money laundering law and looks forward to its adoption.

54. It is recommended that the next Article IV consultation take place on the standard 12-month cycle. 
Chart 1. Cambodia: Selected Economic Indicators, January 1997- June 2004

General Governmental Revenue

(3-month average, in billions of riel)

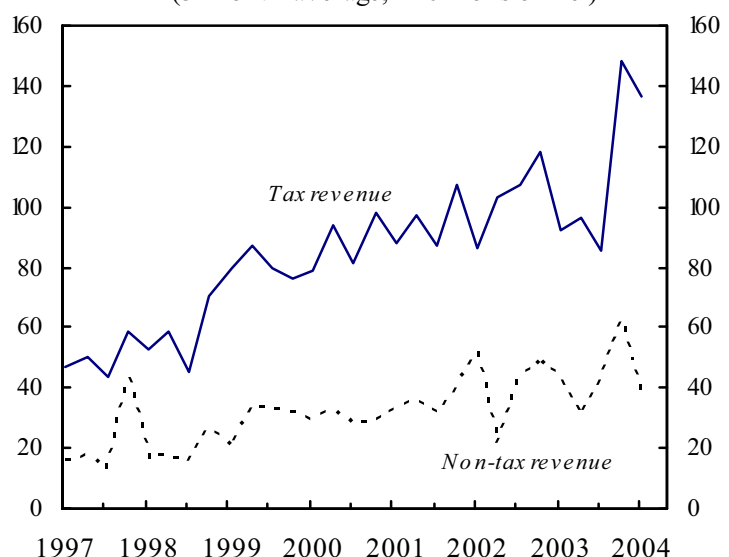

Consumer Price Index

(12-month percent change)

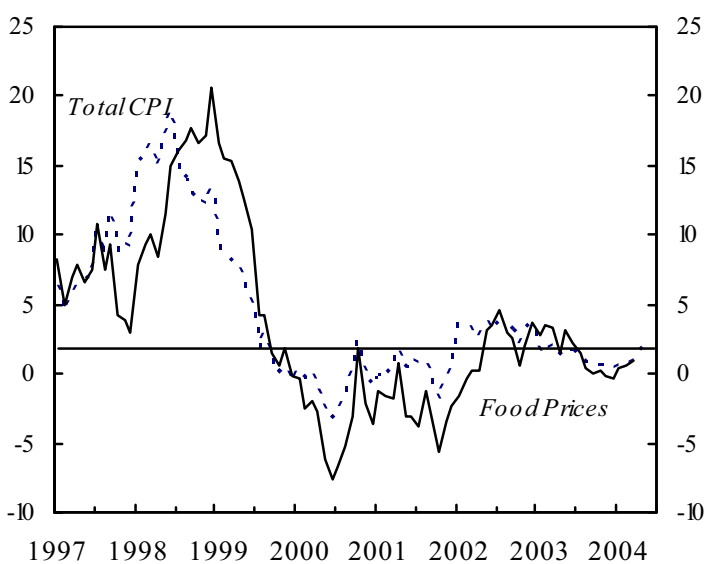

Monetary Indicators

(12-month percent change)

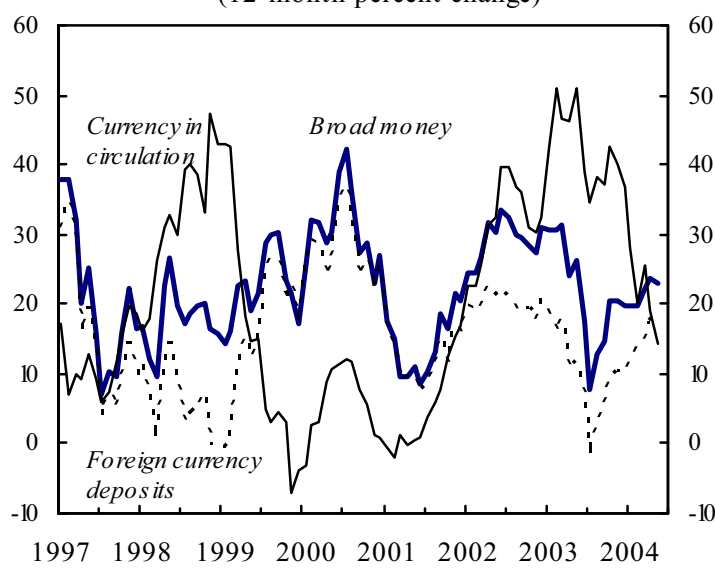

General Government Expenditure

(3-month average, in billions of riel)

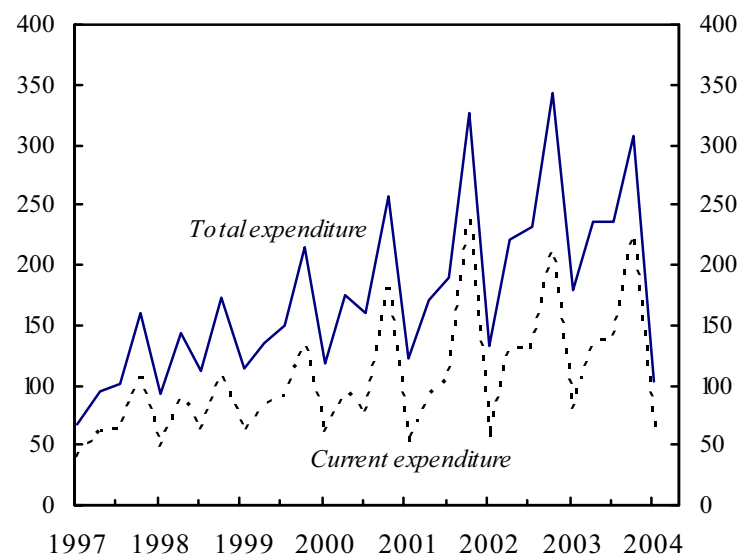

International Reserves

(In millions of U.S. dollars)

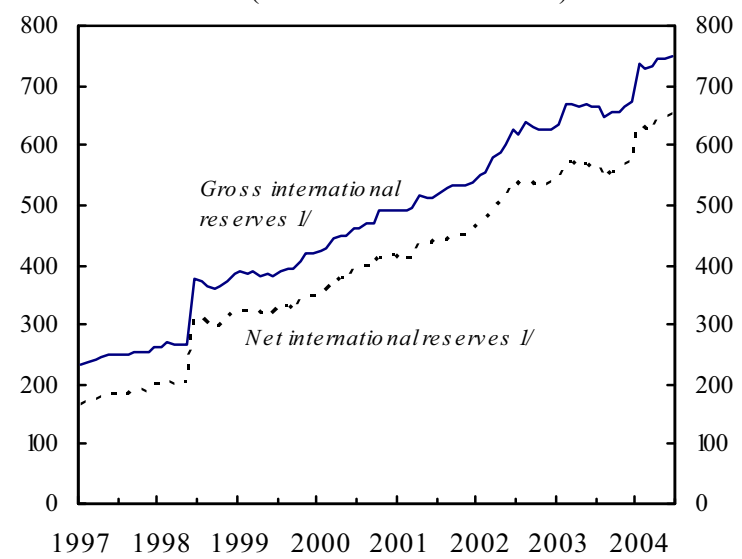

Exchange Rate

$(2000=100)$

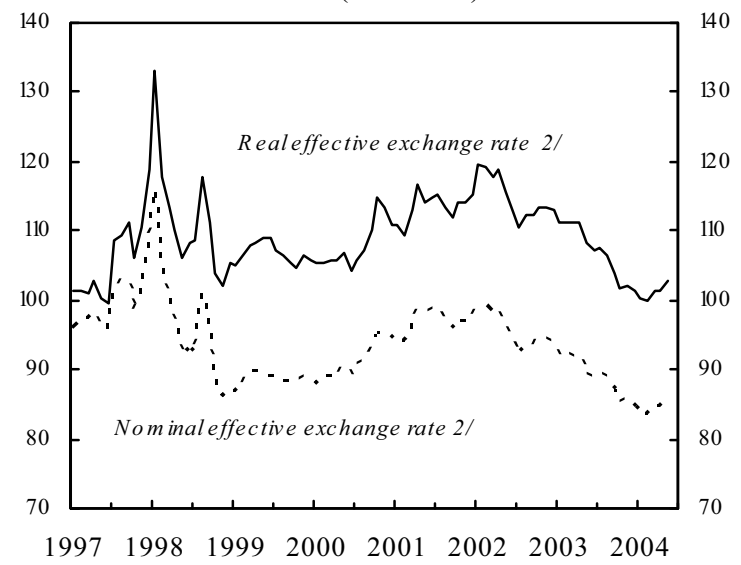

Source: Data provided by the Cambodia authorities

1/ Includes US\$117 million associated with the return in 1998 of Cambodian gold previously held by the BIS.

2/ Based on the official exchange rate; an upward movement indicates an appreciation of the exchange rate. 
Chart 2. Cambodia: Performance Indicators, 1998-2004
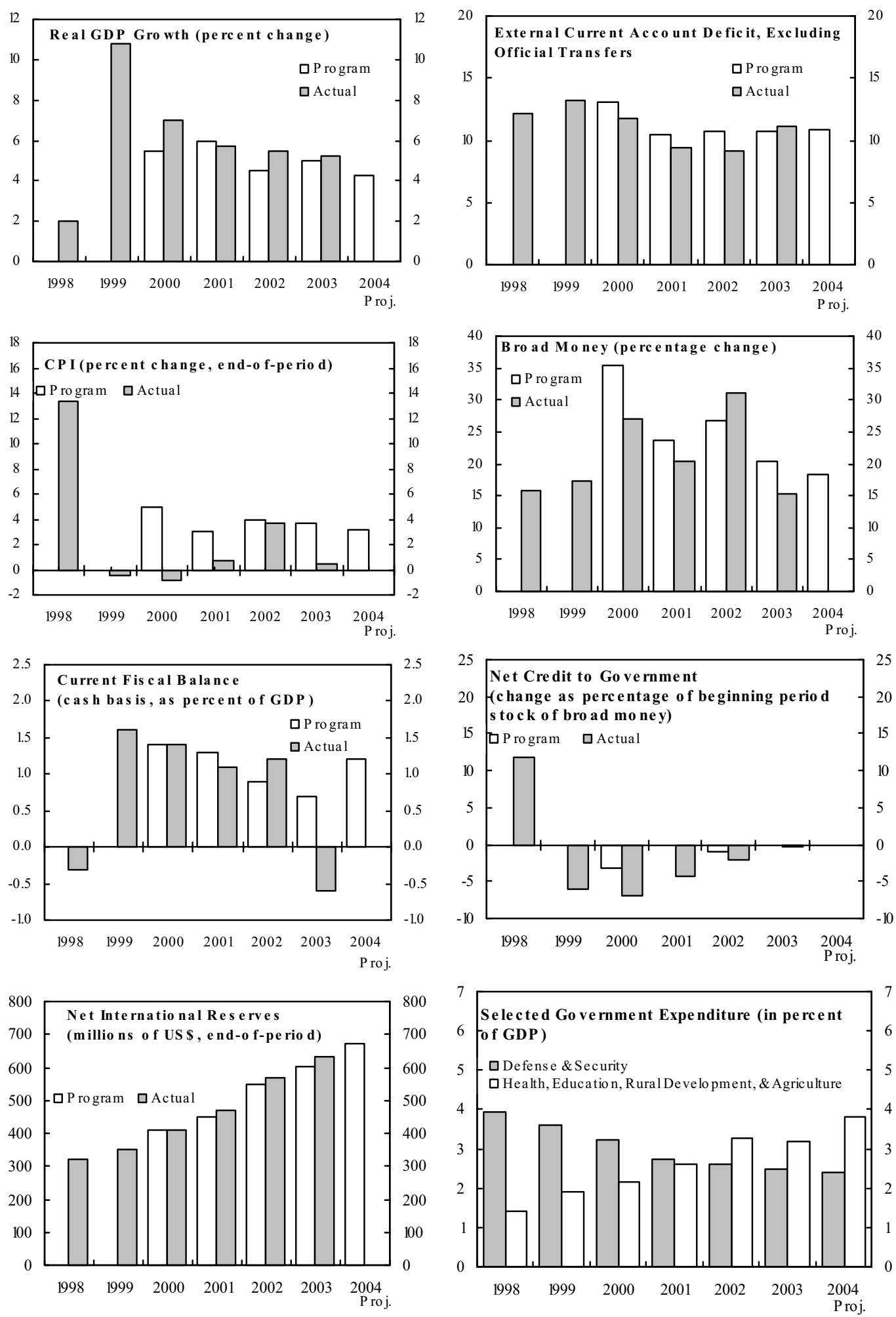

Source: Data provided by the Cambodian authorities, and Fund staff estimates. 
Table 1. Cambodia: Selected Economic Indicators, 1999-2004

Nominal GDP (2002): $\$ 3,996$ million

Population (2002): 13.5 million

GDP per capita (2002): $\$ 296$

Fund Quota:

SDR87.5 million

\begin{tabular}{|c|c|c|c|c|c|c|c|}
\hline & 1999 & 2000 & 2001 & 2002 & 20 & & 2004 \\
\hline & & & & & 6th Rev & Prelim. & Proj. \\
\hline & & & ent chang & & & & \\
\hline Real economy & & & & & & & \\
\hline Real GDP & 10.8 & 7.0 & 5.7 & 5.5 & 5.0 & 5.2 & 4.3 \\
\hline GDP deflator & 2.1 & -1.7 & -0.3 & 2.1 & 3.7 & 1.6 & 2.0 \\
\hline CPI Inflation (end of period) & -0.5 & -0.8 & 0.7 & 3.7 & 3.7 & 0.5 & 3.2 \\
\hline & & (In & cent of Gl & & & & \\
\hline Domestic investment & 17.0 & 17.3 & 21.2 & 22.2 & 16.9 & 21.0 & 20.0 \\
\hline Government investment & 5.4 & 6.3 & 6.6 & 7.8 & 7.1 & 7.4 & 7.3 \\
\hline Non-budgetary grant-financed investment & 5.4 & 6.1 & 5.5 & 4.9 & $\ldots$ & 5.3 & 5.2 \\
\hline Nongovernment investment & 6.2 & 4.9 & 9.1 & 9.5 & 9.8 & 8.3 & 7.4 \\
\hline Of which: change in inventories & 1.5 & -1.4 & 2.1 & -0.4 & $\ldots$ & $\ldots$ & $\ldots$ \\
\hline National saving & 11.8 & 14.4 & 20.1 & 21.3 & 13.9 & 18.6 & 16.7 \\
\hline Government saving & 1.6 & 1.4 & 1.1 & 1.2 & 1.1 & -0.6 & 1.2 \\
\hline Nongovernment saving & 10.3 & 13.0 & 19.0 & 20.2 & 12.8 & 19.2 & 15.4 \\
\hline & (In $\mathrm{p}$ & ent chang & inless oth & vise indica & & & \\
\hline Money and credit & & & & & & & \\
\hline Broad money & 17.3 & 26.9 & 20.4 & 31.1 & 20.5 & 15.3 & 14.1 \\
\hline Of which: riels in circulation & -3.8 & 1.0 & 16.8 & 32.6 & 22.0 & 18.6 & 16.0 \\
\hline Net credit to the government 1 / & -6.1 & -6.9 & -4.3 & -2.0 & 0.0 & -0.3 & 0.0 \\
\hline Velocity of money $2 /$ & 9.7 & 7.8 & 7.2 & 6.0 & 5.1 & 5.6 & 5.0 \\
\hline & & (In & cent of Gl & & & & \\
\hline Government budget & & & & & & & \\
\hline Revenue (incl. capital revenue) & 10.2 & 10.4 & 10.7 & 11.2 & 12.7 & 10.4 & 11.9 \\
\hline Of which: Tax revenue & 7.4 & 7.6 & 7.8 & 7.9 & 8.5 & 7.3 & 8.2 \\
\hline Nontax revenue & 2.7 & 2.6 & 2.9 & 3.2 & 3.6 & 3.1 & 3.3 \\
\hline Additional revenue & $\ldots$ & - & $\ldots$ & $\ldots$ & 0.4 & 0.0 & 0.4 \\
\hline Expenditure & 14.1 & 15.3 & 16.3 & 17.8 & 19.0 & 17.4 & 18.0 \\
\hline Current expenditure & 8.5 & 8.9 & 9.6 & 10.1 & 11.4 & 11.0 & 10.7 \\
\hline Capital expenditure $3 /$ & 5.5 & 6.5 & 6.7 & 7.9 & 7.3 & 7.3 & 7.3 \\
\hline Overall budget balance & -3.9 & -4.9 & -5.5 & -6.7 & -6.3 & -7.0 & -6.1 \\
\hline Overall budget balance (incl. grants) & -1.3 & -2.1 & -2.8 & -3.8 & -3.4 & -4.5 & -3.8 \\
\hline Net Foreign financing & 3.9 & 5.1 & 5.2 & 7.0 & 6.5 & 6.0 & 6.1 \\
\hline Domestic financing (including outstanding operations) 4 & 0.0 & -0.2 & 0.3 & -0.4 & -0.2 & 0.9 & 0.0 \\
\hline & (In millio & of U.S. d & rs; unless & herwise in & ated) & & \\
\hline Balance of payments & & & & & & & \\
\hline Domestic exports & 997 & 1,283 & 1,462 & 1,638 & 1,571 & 1,960 & 2,117 \\
\hline Retained imports & $-1,490$ & $-1,849$ & $-2,010$ & $-2,228$ & $-2,041$ & $-2,524$ & $-2,836$ \\
\hline Current account (excl. official transfers) & -456 & -421 & -348 & -359 & -405 & -429 & -489 \\
\hline (in percent of GDP) & -13.2 & -11.7 & -9.4 & -9.0 & -10.4 & -10.2 & -10.8 \\
\hline Current account (incl. official transfers) & -180 & -104 & -45 & -48 & -118 & -101 & -151 \\
\hline (in percent of GDP) & -5.2 & -2.9 & -1.2 & -1.2 & -3.0 & -2.4 & -3.3 \\
\hline Capital account & 81 & 42 & 91 & 107 & 133 & 133 & 156 \\
\hline Overall balance & -99 & -62 & 45 & 60 & 14 & 33 & 5 \\
\hline Financing gap 5/ & $\ldots$ & $\ldots$ & $\ldots$ & $\ldots$ & 31 & $\ldots$ & 20 \\
\hline Gross official reserves & 422 & 484 & 548 & 663 & 696 & 737 & 782 \\
\hline (in months of imports of goods and services) & 2.7 & 2.6 & 2.7 & 3.0 & 3.3 & 2.9 & 2.8 \\
\hline Net internationa reserves & 349 & 411 & 468 & 567 & 604 & 633 & 670 \\
\hline Public external debt 6/ & 2,315 & 2,394 & 2,489 & 2,735 & 1,671 & 2,981 & 2,088 \\
\hline (in percent of GDP) & 66.5 & 66.8 & 67.2 & 68.4 & 39.8 & 70.8 & 46.3 \\
\hline Public debt service (accrual basis) & 131.4 & 136.2 & 62.0 & 63.1 & 54.0 & 71.2 & 54.3 \\
\hline (in percent of domestic exports of goods and services) & 10.2 & 8.0 & 3.1 & 2.8 & 2.6 & 2.9 & 2.0 \\
\hline Memorandum items: & & & & & & & \\
\hline Nominal GDP (in billions of riels) & 13,131 & 13,810 & 14,544 & 15,667 & 15,650 & 16,748 & 17,815 \\
\hline (in millions of U.S. dollars) & 3,443 & 3,583 & 3,706 & 3,999 & 3,891 & 4,208 & 4,507 \\
\hline Exchange rate (riels per dollar; end of period) & 3,775 & 3,910 & 3,900 & 3,935 & 4,095 & 3,980 & $\ldots$ \\
\hline
\end{tabular}

Sources: Data provided by the Cambodian authorities; and Fund staff estimates and projections.

1/ Contributions to 12-month percent change of broad money.

2/ Ratio of nominal GDP to average stock of broad money.

3/ Includes net lending, and compensation payments to Thailand in 2003 .

4/ Includes funds in transit and payment orders in excess of cash released.

5/ The financing gap is expected to be closed either by a PRGF and World Bank's PRSC or by lower reserve accumulation.

6/ A Paris Club rescheduling under Naples terms (67 percent NPV reduction) is assumed in 2004.

\section{CInternational Monetary Fund. Not for Redistribution}


Table 2. Cambodia: Balance of Payments, 2000-09 ( In millions of U.S. dollars)

\begin{tabular}{|c|c|c|c|c|c|c|c|c|c|c|}
\hline & 2000 & 2001 & 2002 & 2003 & 2004 & 2005 & 2006 & 2007 & 2008 & 2009 \\
\hline & & & & & \multicolumn{6}{|c|}{ Projections } \\
\hline Current account (excluding official transfers) & -421 & -348 & -359 & -429 & -489 & -545 & -565 & -567 & -566 & -567 \\
\hline Current account (including official transfers) & -104 & -45 & -48 & -101 & -151 & -197 & -206 & -198 & -190 & -183 \\
\hline Trade balance & -538 & -523 & -564 & -537 & -692 & -813 & -912 & -993 & $-1,071$ & $-1,151$ \\
\hline Exports, f.o.b. & 1,401 & 1,571 & 1,749 & 2,076 & 2,230 & 2,026 & 2,038 & 2,160 & 2,316 & 2,486 \\
\hline Domestic exports & 1,283 & 1,462 & 1,638 & 1,960 & 2,117 & 1,916 & 1,930 & 2,054 & 2,212 & 2,382 \\
\hline Garment & 986 & 1,156 & 1,338 & 1,607 & 1,794 & 1,587 & 1,590 & 1,699 & 1,839 & 1,991 \\
\hline Non-garment & 297 & 306 & 300 & 353 & 323 & 329 & 341 & 355 & 373 & 392 \\
\hline Forestry & 100 & 68 & 38 & 25 & 27 & 28 & 30 & 33 & 36 & 38 \\
\hline Re-exports & 118 & 109 & 111 & 117 & 113 & 110 & 107 & 106 & 105 & 103 \\
\hline Imports, f.o.b. & $-1,939$ & $-2,094$ & $-2,314$ & $-2,613$ & $-2,922$ & $-2,839$ & $-2,949$ & $-3,153$ & $-3,387$ & $-3,637$ \\
\hline Retained imports, f.o.b. & $-1,849$ & $-2,010$ & $-2,228$ & $-2,524$ & $-2,836$ & $-2,755$ & $-2,867$ & $-3,072$ & $-3,307$ & $-3,558$ \\
\hline Garments sector & -529 & -601 & -699 & -822 & -879 & -763 & -748 & -784 & -832 & -882 \\
\hline Petroleum & -339 & -372 & -371 & -434 & -489 & -453 & -434 & -442 & -454 & -473 \\
\hline Imports for re-export, f.o.b & -91 & -84 & -85 & -90 & -86 & -84 & -82 & -81 & -80 & -79 \\
\hline Services and Income (net) & -26 & 37 & 56 & -54 & 30 & 93 & 170 & 240 & 310 & 388 \\
\hline Services (net) & 101 & 177 & 230 & 120 & 200 & 260 & 316 & 379 & 444 & 519 \\
\hline Credit & 428 & 525 & 604 & 524 & 634 & 697 & 775 & 866 & 969 & 1,085 \\
\hline Of which: Tourism (credit) & 304 & 380 & 454 & 386 & 463 & 534 & 608 & 687 & 777 & 878 \\
\hline Debit & -328 & -347 & -374 & -404 & -434 & -437 & -459 & -487 & -525 & -566 \\
\hline Income (net) & -127 & -140 & -175 & -174 & -170 & -167 & -146 & -139 & -135 & -131 \\
\hline Credit & 67 & 58 & 51 & 44 & 48 & 55 & 75 & 82 & 87 & 92 \\
\hline Debit & -194 & -197 & -225 & -218 & -219 & -223 & -221 & -221 & -222 & -223 \\
\hline Private transfers (net) & 144 & 137 & 149 & 163 & 174 & 175 & 177 & 186 & 195 & 197 \\
\hline Official transfers (net) & 317 & 303 & 312 & 328 & 338 & 348 & 358 & 369 & 376 & 384 \\
\hline Capital and financial account & 42 & 91 & 107 & 133 & 156 & 193 & 218 & 248 & 255 & 286 \\
\hline Medium- and long-term loans & -24 & 64 & 133 & 120 & 170 & 164 & 187 & 183 & 184 & 172 \\
\hline Disbursements & 90 & 98 & 168 & 160 & 187 & 180 & 206 & 205 & 212 & 208 \\
\hline Amortization & -114 & -35 & -34 & -40 & -17 & -16 & -18 & -22 & -28 & -36 \\
\hline Foreign direct investment & 142 & 142 & 139 & 77 & 83 & 83 & 91 & 105 & 121 & 133 \\
\hline Short-term flows and errors and omissions & -75 & -115 & -165 & -65 & -97 & -54 & -61 & -41 & -50 & -19 \\
\hline Overall balance & -62 & 45 & 60 & 33 & 5 & -4 & 11 & 50 & 65 & 104 \\
\hline Financing & 62 & -45 & -60 & -33 & -5 & 4 & -11 & -50 & -65 & -104 \\
\hline Change in gross official reserves & -62 & -64 & -115 & -73 & -45 & -22 & -34 & -48 & -49 & -85 \\
\hline Use of Fund credit & 4 & 9 & 9 & -2 & -10 & -9 & -6 & -11 & -16 & -18 \\
\hline Purchases/disbursements & 11 & 21 & 21 & 12 & 0 & 0 & 0 & 0 & 0 & 0 \\
\hline Repurchases/repayments & 7 & 12 & 12 & 13 & 10 & 9 & 6 & 11 & 16 & 18 \\
\hline Debt restructuring 1 / & 0 & -16 & 0 & 0 & 1,690 & 0 & 0 & 0 & 0 & 0 \\
\hline Debt forgiveness & 0 & -15 & 0 & 0 & 963 & 0 & 0 & 0 & 0 & 0 \\
\hline Debt rescheduling & 0 & -1 & 0 & 0 & 727 & 0 & 0 & 0 & 0 & 0 \\
\hline Change in arrears $(-=$ reduction $)$ & 120 & 26 & 46 & 42 & $-1,659$ & 0 & 0 & 0 & 0 & 0 \\
\hline Financing Gap 2/ & 0 & 0 & 0 & 0 & 20 & 34 & 29 & 10 & 0 & 0 \\
\hline \multicolumn{11}{|l|}{ Memorandum items: } \\
\hline Trade balance (in percent of GDP) & -15.0 & -14.1 & -14.1 & -12.8 & -15.4 & -17.2 & -18.2 & -18.4 & -18.4 & -18.2 \\
\hline \multicolumn{11}{|l|}{ Current account balance } \\
\hline Excluding official transfers (in percent of GDP) & -11.7 & -9.4 & -9.0 & -10.2 & -10.8 & -11.5 & -11.3 & -10.5 & -9.7 & -9.0 \\
\hline Including official transfers (in percent of GDP) & -2.9 & -1.2 & -1.2 & -2.4 & -3.3 & -4.2 & -4.1 & -3.7 & -3.2 & -2.9 \\
\hline Gross official reserves & 484 & 548 & 663 & 737 & 782 & 804 & 838 & 886 & 935 & 1,021 \\
\hline In months of imports of goods \& services & 2.6 & 2.7 & 3.0 & 2.9 & 2.8 & 2.9 & 2.9 & 2.9 & 2.9 & 2.9 \\
\hline Net international reserves & 411 & 468 & 567 & 633 & 670 & 681 & 702 & 752 & 817 & 921 \\
\hline Public debt service, incl IMF (accrual basis) & 136.2 & 62.0 & 63.1 & 71.2 & 54.3 & 58.4 & 60.5 & 70.4 & 83.6 & 95.3 \\
\hline Public debt service ratio, include IMF (accrual basis) & 8.0 & 3.1 & 2.8 & 2.9 & 2.0 & 2.2 & 2.2 & 2.4 & 2.6 & 2.7 \\
\hline Public external debt & 2,394 & 2,489 & 2,735 & 2,981 & 2,088 & 2,283 & 2,499 & 2,684 & 2,853 & 3,008 \\
\hline Public external debt (in percent of GDP) & 66.8 & 67.2 & 68.4 & 70.8 & 46.3 & 48.3 & 49.9 & 49.7 & 48.9 & 47.6 \\
\hline
\end{tabular}

Sources: Data provided by the Cambodian authorities; and Fund staff estimates and projections.

1/ Assumes conclusion of debt rescheduling agreement with the Russian Federation and the United States in mid-2004.

2/ The financing gap is expected to be closed either by a PRGF and World Bank's PRSC, or by lower reserve accumulation. 
Table 3. Cambodia: Monetary Survey, 2000-04

\begin{tabular}{|c|c|c|c|c|c|c|c|c|c|}
\hline & \multirow{2}{*}{$\begin{array}{r}2000 \\
\text { Dec. }\end{array}$} & \multirow{2}{*}{$\begin{array}{l}2001 \\
\text { Dec. }\end{array}$} & \multirow{2}{*}{$\begin{array}{c}2002 \\
\text { Dec. }\end{array}$} & \multirow{2}{*}{$\begin{array}{c}2003 \\
\text { Dec. }\end{array}$} & \multicolumn{3}{|c|}{2004} & \multirow[b]{2}{*}{ Apr. } & \multirow{2}{*}{$\begin{array}{l}2004 \\
\text { Dec. } \\
\text { Proj. }\end{array}$} \\
\hline & & & & & Jan. & Feb. & Mar. & & \\
\hline & \multicolumn{9}{|c|}{ (In billions of riels; end of period) } \\
\hline Net foreign assets & 2,588 & 3,081 & 3,738 & 4,026 & 4,111 & 4,131 & 4,265 & 4,239 & 4,320 \\
\hline National Bank & 2,102 & 2,429 & 3,220 & 3,494 & 3,540 & 3,657 & 3,721 & 3,711 & 3,750 \\
\hline Deposit money banks (DMBs) & 486 & 651 & 517 & 533 & 571 & 474 & 544 & 527 & 570 \\
\hline Net domestic assets & -758 & -917 & -849 & -698 & -636 & -545 & -606 & -549 & -523 \\
\hline Domestic credit & 904 & 868 & 942 & 1,209 & 1,225 & 1,294 & 1,256 & 1,281 & 1,430 \\
\hline Government (net) & 3 & -75 & -119 & -128 & -109 & -104 & -133 & -147 & -128 \\
\hline Public enterprises & 3 & 7 & 2 & 0 & 0 & 0 & 0 & 0 & 0 \\
\hline Private sector & 898 & 936 & 1,059 & 1,337 & 1,335 & 1,398 & 1,389 & 1,428 & 1,558 \\
\hline Other items (net) & $-1,662$ & $-1,784$ & $-1,791$ & $-1,907$ & $-1,861$ & $-1,839$ & $-1,861$ & $-1,829$ & $-1,953$ \\
\hline Of which: capital & $-1,791$ & $-1,959$ & $-1,943$ & $-2,090$ & $-2,070$ & $-2,072$ & $-2,099$ & $-2,067$ & $\ldots$ \\
\hline National Bank & $-1,000$ & $-1,035$ & $-1,134$ & $-1,229$ & $-1,205$ & $-1,202$ & $-1,241$ & $-1,201$ & $\ldots$ \\
\hline DMBs & -791 & -924 & -809 & -861 & -865 & -870 & -858 & -866 & $\ldots$ \\
\hline Broad money & 1,831 & 2,204 & 2,888 & 3,329 & 3,475 & 3,586 & 3,659 & 3,690 & 3,797 \\
\hline Narrow money & 540 & 610 & 813 & 938 & 962 & 991 & 1,007 & 1,029 & 1,076 \\
\hline Currency in circulation & 495 & 578 & 766 & 908 & 930 & 956 & 973 & 996 & 1,054 \\
\hline Demand deposits & 45 & 32 & 47 & 29 & 32 & 35 & 34 & 32 & 23 \\
\hline Quasi-money & 1,291 & 1,594 & 2,075 & 2,391 & 2,513 & 2,595 & 2,652 & 2,661 & 2,721 \\
\hline Time deposits & 46 & 56 & 74 & 82 & 83 & 87 & 88 & 90 & 93 \\
\hline \multirow[t]{2}{*}{ Foreign currency deposits } & 1,245 & 1,539 & 2,001 & 2,310 & 2,430 & 2,508 & 2,564 & 2,572 & 2,627 \\
\hline & \multicolumn{9}{|c|}{ (12 - month percent change) } \\
\hline Net foreign assets & 28.2 & 19.0 & 21.3 & 7.7 & 8.3 & 9.2 & 14.6 & 15.5 & 7.3 \\
\hline Net domestic assets (+ decrease) & 31.5 & 21.0 & -7.4 & -17.8 & -24.7 & -31.6 & -15.7 & -21.6 & -25.1 \\
\hline Private sector & 17.7 & 4.2 & 13.1 & 26.2 & 27.3 & 31.1 & 23.5 & 24.5 & 16.5 \\
\hline Broad money & 26.9 & 20.4 & 31.1 & 15.3 & 17.7 & 20.0 & 21.8 & 24.3 & 14.1 \\
\hline \multirow[t]{2}{*}{ Of which: currency in circulation } & 1.0 & 16.8 & 32.6 & 18.6 & 20.7 & 21.9 & 23.9 & 20.5 & 16.0 \\
\hline & \multicolumn{9}{|c|}{ (Contribution to annual growth of broad money; in percent) } \\
\hline Net foreign assets & 39.5 & 26.9 & 29.8 & 10.0 & 10.6 & 11.6 & 18.1 & 19.2 & 8.8 \\
\hline Net domestic assets & -12.6 & -8.7 & 3.1 & 5.2 & 7.1 & 8.4 & 3.7 & 5.1 & 5.3 \\
\hline Domestic credit & 2.0 & -2.0 & 3.4 & 9.2 & 9.7 & 11.0 & 6.7 & 5.4 & 6.6 \\
\hline Government (net) & -6.9 & -4.3 & -2.0 & -0.3 & 0.0 & 0.0 & -2.0 & -4.1 & 0.0 \\
\hline Private sector & 9.4 & 2.1 & 5.6 & 9.6 & 9.7 & 11.1 & 8.8 & 9.5 & 6.6 \\
\hline Other items (net) & -14.5 & -6.7 & -0.3 & -4.0 & -2.6 & -2.6 & -3.0 & -0.3 & -1.4 \\
\hline \multicolumn{10}{|l|}{ Memorandum items: } \\
\hline Foreign currency deposits (in millions of dollars) & 318 & 395 & 508 & 580 & 609 & 628 & 643 & 643 & 669 \\
\hline Foreign currency deposits (in percent of broad money) & 68 & 70 & 69 & 69 & 70 & 70 & 70 & 70 & 69 \\
\hline Riel component of broad money & 586 & 665 & 888 & 1,020 & 1,045 & 1,078 & 1,095 & 1,118 & 1,170 \\
\hline (in percent of broad money) & 32 & 30 & 31 & 31 & 30 & 30 & 30 & 30 & 31 \\
\hline Credit to the private sector (in millions of dollars) & 230 & 240 & 269 & 336 & 335 & 350 & 348 & 357 & 397 \\
\hline Velocity $1 /$ & 7.8 & 7.2 & 6.0 & 5.6 & 5.5 & 5.4 & 5.4 & 5.3 & 5.0 \\
\hline
\end{tabular}

Source: Data provided by the Cambodian authorities; and Fund staff projections.

1/ Nominal GDP divided by the average stock of broad money. 
Table 4a. Cambodia: General Government Operations, 2000-04

(In billion of riels)

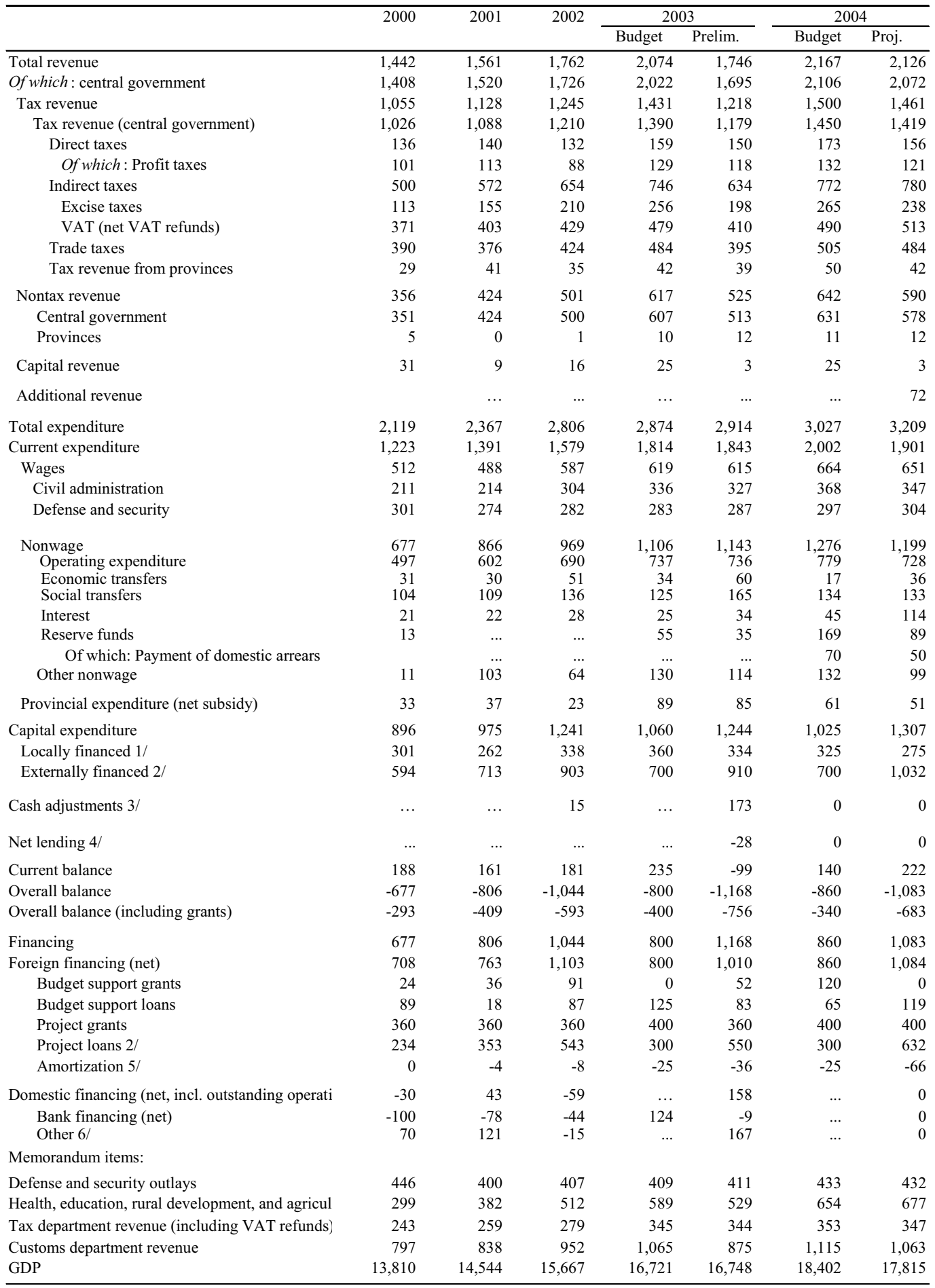

1/ For 2003 and 2004, data include compensation payments to Thailand.

2/ Includes CR 137 billion from bilateral donors for 2002, CR 92 billion for 2003, and CR 116 billion for 2004

3 / Cash payments on expenditure committed in the previous year (-); or expenditure committed but for which cash has not yet been disbursed (+).

4/ Includes CR 28 billion of early repayment by the water supply company on onlent World Bank loan, and CR 16 billion loan by the electricity company.

5 / Includes \$2.8 million repayment to IDA in 2003 .

6/ Includes funds in transit and payment orders in excess of cash released. 
Table 4b. Cambodia: General Government Operations, 2000-04

\begin{tabular}{|c|c|c|c|c|c|c|c|}
\hline & \multirow[t]{2}{*}{2000} & \multirow[t]{2}{*}{2001} & \multirow[t]{2}{*}{2002} & \multicolumn{2}{|c|}{2003} & \multicolumn{2}{|c|}{2004} \\
\hline & & & & Budget & $\overline{\text { Prelim. }}$ & Budget & Proj. \\
\hline Total revenue & 10.4 & 10.7 & 11.2 & 12.4 & 10.4 & 11.8 & 11.9 \\
\hline Of which: central government & 10.2 & 10.5 & 11.0 & 12.1 & 10.1 & 11.4 & 11.6 \\
\hline Tax revenue & 7.6 & 7.8 & 7.9 & 8.5 & 7.3 & 8.1 & 8.2 \\
\hline Tax revenue (central government) & 7.4 & 7.5 & 7.7 & 8.3 & 7.0 & 7.9 & 8.0 \\
\hline Direct taxes & 1.0 & 1.0 & 0.8 & 1.0 & 0.9 & 0.9 & 0.9 \\
\hline Of which: Profit taxes & 0.7 & 0.8 & 0.6 & 0.8 & 0.7 & 0.7 & 0.7 \\
\hline Indirect taxes & 3.6 & 3.9 & 4.2 & 4.5 & 3.8 & 4.2 & 4.4 \\
\hline Excise taxes & 0.8 & 1.1 & 1.3 & 1.5 & 1.2 & 1.4 & 1.3 \\
\hline VAT (net VAT refunds) & 2.7 & 2.8 & 2.7 & 2.9 & 2.4 & 2.7 & 2.9 \\
\hline Trade taxes & 2.8 & 2.6 & 2.7 & 2.9 & 2.4 & 2.7 & 2.7 \\
\hline Tax revenue from provinces & 0.2 & 0.3 & 0.2 & 0.2 & 0.2 & 0.3 & 0.2 \\
\hline Nontax revenue & 2.6 & 2.9 & 3.2 & 3.7 & 3.1 & 3.5 & 3.3 \\
\hline Central government & 2.5 & 2.9 & 3.2 & 3.6 & 3.1 & 3.4 & 3.2 \\
\hline Provinces & 0.0 & 0.0 & 0.0 & 0.1 & 0.1 & 0.1 & 0.1 \\
\hline Capital revenue & 0.2 & 0.1 & 0.1 & 0.1 & 0.0 & 0.1 & 0.0 \\
\hline Additional revenue & $\ldots$ & $\ldots$ & $\ldots$ & $\cdots$ & $\cdots$ & $\cdots$ & 0.4 \\
\hline Total expenditure & 15.3 & 16.3 & 17.8 & 17.2 & 17.4 & 16.4 & 18.0 \\
\hline Current expenditure & 8.9 & 9.6 & 10.1 & 10.8 & 11.0 & 11.2 & 10.7 \\
\hline Wages & 3.7 & 3.4 & 3.7 & 3.7 & 3.7 & 3.7 & 3.7 \\
\hline Civil administration & 1.5 & 1.5 & 1.9 & 2.0 & 2.0 & 2.1 & 1.9 \\
\hline Defense and security & 2.2 & 1.9 & 1.8 & 1.7 & 1.7 & 1.7 & 1.7 \\
\hline Nonwage & 4.9 & 6.0 & 6.2 & 6.6 & 6.8 & 6.9 & 6.7 \\
\hline Operatıng expenditure & 3.6 & 4.1 & 4.4 & 4.4 & 4.4 & 4.2 & 4.1 \\
\hline Economic transfers & 0.2 & 0.2 & 0.3 & 0.2 & 0.4 & 0.1 & 0.2 \\
\hline Social transfers & 0.8 & 0.7 & 0.9 & 0.7 & 1.0 & 0.7 & 0.7 \\
\hline Interest & 0.2 & 0.1 & 0.2 & 0.1 & 0.2 & 0.2 & 0.6 \\
\hline Reserve funds & 0.1 & $\ldots$ & 0.0 & 0.3 & 0.2 & 0.9 & 0.5 \\
\hline Of which: Payment of domestic arrears & & & $\ldots$ & $\ldots$ & $\ldots$ & 0.4 & 0.3 \\
\hline Other nonwage & 0.1 & 0.7 & 0.4 & 0.8 & 0.7 & 0.7 & 0.6 \\
\hline Provincial expenditure (net subsidy) & 0.2 & 0.3 & 0.1 & 0.5 & 0.5 & 0.3 & 0.3 \\
\hline Capital expenditure & 6.5 & 6.7 & 7.9 & 6.3 & 7.4 & 5.6 & 7.3 \\
\hline Locally financed $1 /$ & 2.2 & 1.8 & 2.2 & 2.1 & 2.0 & 1.8 & 1.5 \\
\hline Externally financed $2 /$ & 4.3 & 4.9 & 5.8 & 4.2 & 5.4 & 3.8 & 5.8 \\
\hline Cash adjustments 3 / & $\cdots$ & $\cdots$ & 0.1 & $\cdots$ & 1.0 & 0.0 & 0.0 \\
\hline Net lending 4/ & $\cdots$ & $\cdots$ & $\ldots$ & $\ldots$ & -0.2 & 0.0 & 0.0 \\
\hline Current balance & 1.4 & 1.1 & 1.2 & 1.4 & -0.6 & 0.8 & 1.2 \\
\hline Overall balance & -4.9 & -5.5 & -6.7 & -4.8 & -7.0 & -4.7 & -6.1 \\
\hline Overall balance (including grants) & -2.1 & -2.8 & -3.8 & -2.4 & -4.5 & -1.8 & -3.8 \\
\hline Financing & 4.9 & 5.5 & 6.7 & 4.8 & 7.0 & 4.7 & 6.1 \\
\hline Foreign financing (net) & 5.1 & 5.2 & 7.0 & 4.8 & 6.0 & 4.7 & 6.1 \\
\hline Budget support grants & 0.2 & 0.2 & 0.6 & 0.0 & 0.3 & 0.7 & 0.0 \\
\hline Budget support loans & 0.6 & 0.1 & 0.6 & 0.7 & 0.5 & 0.4 & 0.7 \\
\hline Project grants & 2.6 & 2.5 & 2.3 & 2.4 & 2.1 & 2.2 & 2.2 \\
\hline Project loans 2/ & 1.7 & 2.4 & 3.5 & 1.8 & 3.3 & 1.6 & 3.5 \\
\hline Amortization 5/ & 0.0 & 0.0 & 0.0 & -0.1 & -0.2 & -0.1 & -0.4 \\
\hline Domestic financing (net, incl. outstanding operation & -0.2 & 0.3 & -0.4 & $\ldots$ & 0.9 & $\ldots$ & 0.0 \\
\hline Bank financing (net) & -0.7 & -0.5 & -0.3 & $\ldots$ & -0.1 & $\ldots$ & 0.0 \\
\hline Other $6 /$ & 0.5 & 0.8 & -0.1 & $\ldots$ & 1.0 & $\ldots$ & 0.0 \\
\hline \multicolumn{8}{|l|}{ Memorandum items: } \\
\hline Defense and security outlays & 3.2 & 2.8 & 2.6 & 2.4 & 2.5 & 2.4 & 2.4 \\
\hline Health, education, rural development, and agricultur & 2.2 & 2.6 & 3.3 & 3.5 & 3.2 & 3.6 & 3.8 \\
\hline Tax department revenue (including VAT refunds) & 1.8 & 1.8 & 1.8 & 2.1 & 2.1 & 1.9 & 1.9 \\
\hline Customs department revenue & 5.8 & 5.8 & 6.1 & 6.4 & 5.2 & 6.1 & 6.0 \\
\hline
\end{tabular}

1/ For 2003 and 2004, data include compensation payments to Thailand.

2/ Includes CR 137 billion from bilateral donors for 2002, CR 92 billion for 2003, and CR 116 billion for 2004.

3/ Cash payments on expenditure committed in the previous year (-); or expenditure committed but for which cash has not yet been disbursed $(+)$.

4/ Includes CR 28 billion of early repayment by the water supply company on onlent World Bank loan, and CR 16 billion loan by the electricity company.

$5 /$ Includes \$2.8 million repayment to IDA in 2003.

6/ Includes funds in transit and payment orders in excess of cash released. 
Table 5. Cambodia: Medium-Term Macroeconomic Framework, 2002-09

(In percent of GDP, unless otherwise indicated)

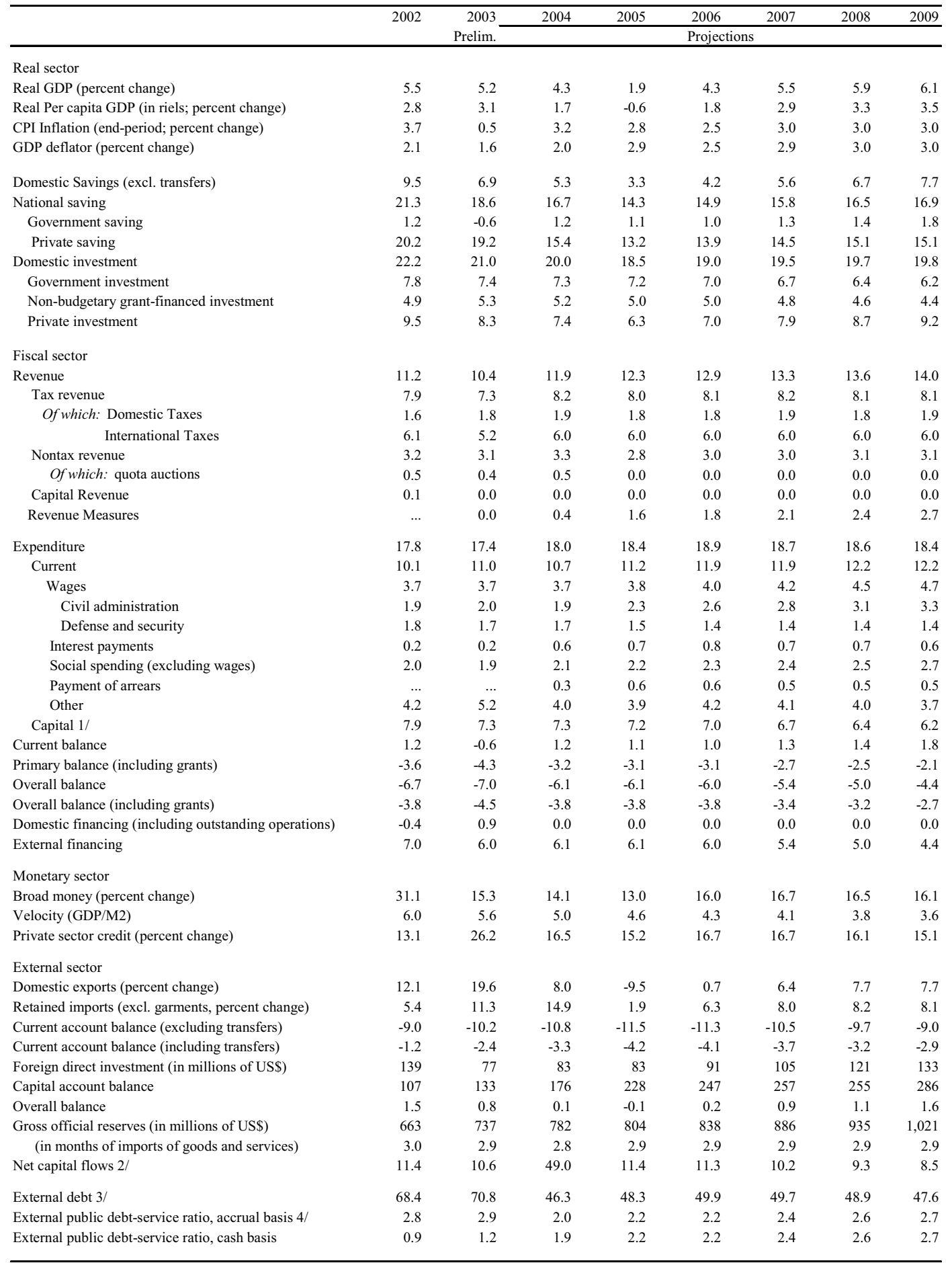

Sources: Data provided by Cambodian authorities; and Fund staff estimates and projections.

1/ Includes net lending and compensation payments to Thailand in 2003.

2/ Net official disbursement, exceptional financing, financing gap, and official transfers.

3/ Assumes conclusion of debt rescheduling agreement with the Russian Federation and the United States in mid-2004.

4/ As percent of domestic exports of goods and services. The decline in 2004 reflects the tailing off of payments to the Russian Federation. 
Table 6. Cambodia: Fiscal Reform Agenda

\begin{tabular}{l}
\hline Area \\
\hline I. Tax Policy Reforms \\
II. Revenue Administration \\
a. Tax Administration
\end{tabular}

a. Tax Administration

Collect tax arrears, including through escalating penalty measures

2004-07

Implement measures in $2004 \mathrm{H} 2$ to yield 0.8 percent of GDP

Timing

Enforce Tax Law amendments on depreciation, withholding on payments to non-

residents, and provisions related to NGOs and IFIs

2004

Introduce additional measures to reach revenue target of 14 percent of GDP

2004

2006-09

Adopt new organization structure, expand staff and training, and add Appeals Unit

2004-06

Complete de-registration program and implement new audit program

2003-07

Extend the same procedures for Large Taxpayer Unit to medium taxpayers

2004-06

Establish new computerization program for collection, audit, and cross-checking

Provide training on international audit and tax avoidance

b. Customs
administration

Adopt Law on Customs and promulgate supporting regulations

2004-05

2006-07

Continue to strengthen anti-smuggling efforts

2004

Automate Customs systems and procedures

continuous

Reduce number of required inspections to facilitate trade

2004-05

Implement new organization structure

2004-05

2005-06

Establish Customs Fraud Investigation Unit

2005-07

Consolidate various non-tax revenue units in one department

2004-05

Identify and start collecting nontax arrears

2004-06

Audit operations of contracts and leases to verify compliance

Review financial terms of contracts with significant fiscal implications

continuous

2005-07

III.Expenditure Policy
a. Reduce arrears
b. Social spending
c. Defense
d. Civil service

Make provisions in annual budgets for eliminating arrears by 2008

2004-08

Raise spending to reach NPRS target of 37 percent of current expenditure

2005

Reduce the share of spending on executive functions and overheads

2005-07

Reduce spending to meet NPRS target of 19.4 percent of current expenditure

2005

Based on studies completed in 2004, begin implementation of reforms, including decompressing the wage structure

2005-07

IV.Budgetary Process

a. Budget system

Establish an Interdepartmental Committee to implement reforms

Adopt first phase reform program under an enhanced framework of donor

coordination

Use input from revenue departments and line ministries on monthly projections

2003-07

Gradually unify the budget system, including foreign currency units

2003-06

Synchronize preparation of MTEF with annual budget cycle

2004-07

Expand coverage of MTEF to include all ministries

2005-06

Integrate MTEF with the medium-term wage framework and public investment

program

c. Treasury reform

Introduce new chart of accounts and revise coding system

2005-06

Transfer the banking function of the NT to banks

2003-06

2004-06

Develop financial control and internal audit within ministries

2004-06

d. Cash management

Strengthen legal framework and create Central Procurement Monitoring Office

2004-05 
Table 7. Cambodia: Schedule for Enacting Laws for WTO Conformity

\begin{tabular}{|c|c|c|c|c|c|c|}
\hline & 2001 & 2002 & 2003 & $2004^{1}$ & $2005^{1}$ & $2006^{1}$ \\
\hline \multicolumn{7}{|l|}{ Judicial Reform } \\
\hline 1 Law Establishing the Commercial Court & & & & Expected & & \\
\hline $\begin{array}{l}2 \text { Ratification of the New York Convention on the Enforcement of Foreign } \\
\text { Arbitral Awards }\end{array}$ & Adopted & & & & & \\
\hline 3 Commercial Arbitration Law & & & & Expected & & \\
\hline 4 Ratification of the ICSID Convention & Adopted & & & & & \\
\hline 5 Civil Code & & & & Expected & & \\
\hline 6 Civil Procedure Code & & & & Expected & & \\
\hline 7 Criminal Code & & & & & Expected & \\
\hline 8 Criminal Procedure Code & & & & & Expected & \\
\hline \multicolumn{7}{|l|}{ Trade-Related Intellectual Property Rights (TRIPS) } \\
\hline 1 Law on Trademarks and Acts of Unfair Competition & Adopted & & & & & \\
\hline 2 Law on Protection of Patent, Utility Models, and Industrial Designs & & Adopted & & & & \\
\hline 3 Law on Copyrights and Related Rights & & & Adopted & & & \\
\hline 4 Law on Geographical Indications Including Appellation of Origin & & & & Expected & & \\
\hline 5 Laws on Layout Designs of Integrated Circuit & & & & & Expected & \\
\hline 6 Law on Plant Variety Protection & & & & & Expected & \\
\hline 7 Law on Protection of Undisclosed Information & & & & & Expected & \\
\hline \multicolumn{7}{|c|}{ Technical Barriers to Trade (TBT), and Sanitary and Phytosanitary (SPS) Measures } \\
\hline 1 Sub-degree on Inquiry Points for (1) Services, (2) SPS, and (3) TBT & & Adopted & & & & \\
\hline 2 Sub-Decree on Animal Quarantine & & & Adopted & & & \\
\hline 3 Sub-Decree on Plant Quarantine & & & Adopted & & & \\
\hline \multicolumn{7}{|l|}{ Custom Valuation } \\
\hline 1 Custom Code & & & & Expected & & \\
\hline 2 Law on Rule of Origin & & & & Expected & & \\
\hline 3 Law on Anti-dumping Measures and on Countervailing Measures & & & & & Expected & \\
\hline \multicolumn{7}{|l|}{ Trade-Related Investment Measures (TRIM) } \\
\hline 1 Amendment of Law on Investment & & & Adopted & & & \\
\hline 2 Law on Export Processing Zones & & & & Expected & & \\
\hline \multicolumn{7}{|l|}{ Financial Intermediation } \\
\hline 1 Negotiable and Payment Transaction Law & & & & Expected & & \\
\hline 2 Accounting Law & & Adopted & & & & \\
\hline 3 Insolvency Law & & & & Expected & & \\
\hline 4 Secured Transaction Law & & & & Expected & & \\
\hline 5 Securities and Exchange Law & & & & & & Expected \\
\hline 6 Commercial Leasing Law & & & & & Expected & \\
\hline \multicolumn{7}{|l|}{ Other areas } \\
\hline 1 Postal Service Law & & Adopted & & & & \\
\hline 2 Water Supply Law & & & & Expected & & \\
\hline 3 Water Resources Management Law & & & & Expected & & \\
\hline 4 Telecommunication Law & & & & Expected & & \\
\hline 5 Tourism and Entertainment Law & & & & Expected & & \\
\hline 6 Civil Aviation Law & & & & Expected & & \\
\hline 7 Merchant Shipping Law & & & & & Expected & \\
\hline 8 Land Traffic Law (Highway Code) & & & & Expected & & \\
\hline 9 Fisheries Law & & & & Expected & & \\
\hline 10 Forestry Law & & Adopted & & Expected & & \\
\hline 11 Land Law & Adopted & & & & & \\
\hline 12 Royal Decree on Cooperative & Adopted & & & & & \\
\hline 13 Commercial Contracts Law & & & & Expected & & \\
\hline 14 Commercial Agency Law & & & & & Expected & \\
\hline 15 Competition Law & & & & & & Expected \\
\hline 16 Law on Safeguard Measures & & & & & Expected & \\
\hline 17 Law on Business Enterprises & & & & Expected & & \\
\hline
\end{tabular}

Source: The Cambodian authorities

${ }^{1}$ Due to the political impasse, the expected dates of enactment are now delayed by about a year. 


\section{Cambodia: Fund Relations}

As of June 30, 2004

I. Membership Status: Joined: 12/31/1969; Article XIV

II. General Resources Account:

Quota

Fund Holdings of Currency

III. SDR Department:

Net cumulative allocation

Holdings

IV. Outstanding Purchases and Loans:

PRGF arrangements
SDR Million

87.50

87.50

SDR Million

15.42

0.15

SDR Million

65.50

Amount Approved

(SDR Million)

58.50

84.00

\author{
Percent Quota \\ 100.00 \\ 100.00
}
Percent Allocation
100.00
0.99

Percent Quota

74.86

V. Financial Arrangements:

Type

ESAF/PRGF

ESAF
Approval

10/22/1999

$05 / 06 / 1994$
Expiration

Date

$03 / 05 / 2003$

$08 / 31 / 1997$
Amount Drawn

(SDR Million)

58.50

42.00

VI. Projected Obligations to Fund: (SDR Million; based on existing use of resources and present holdings of SDRs):

\begin{tabular}{|c|c|c|c|c|c|c|}
\hline & \multirow{2}{*}{$\begin{array}{l}\text { Overdue } \\
5 / 30 / 2004 \\
\end{array}$} & \multicolumn{5}{|c|}{ Forthcoming } \\
\hline & & $\underline{2004}$ & $\underline{2005}$ & $\underline{2006}$ & 2007 & $\underline{2008}$ \\
\hline Principal & -- & 2.80 & 5.87 & 4.18 & 7.52 & 10.86 \\
\hline Charges/Interest & -- & $\underline{0.30}$ & $\underline{0.58}$ & $\underline{0.55}$ & $\underline{0.52}$ & $\underline{0.47}$ \\
\hline Total & -- & $\underline{3.10}$ & $\underline{6.45}$ & $\underline{4.73}$ & $\underline{8.04}$ & $\underline{11.34}$ \\
\hline
\end{tabular}

VII. Safeguards Assessment:

Under the Fund's safeguard assessment policy, the National Bank of Cambodia (NBC) is subject to a full safeguard assessment with respect to a possible successor PRGF Arrangement. The assessment was completed on March 24, 2004 and specific measures were proposed to address a few weaknesses. 


\section{Exchange Rate Arrangement:}

Since November 8, 1992 the exchange rate arrangement for the riel has consisted of the following two rates. First, the official exchange rate, which is expressed in riels per U.S. dollar, applies to all official external transactions conducted by the government and state enterprises. Second, the market rate, which is determined by the foreign exchange market, applies to all other transactions. The official exchange rate is adjusted so as to limit the spread between the official rate and the market rate to no more than 1 percent on a daily basis. On July 25, 2004, the official exchange rate was CR 4,024 per U.S. dollar and the market rate CR 4,038 per U.S. dollar. Cambodia accepted the obligations of Article VIII, Sections 2, 3, and 4 on January 1, 2002. Cambodia maintains an exchange system that is free of restrictions on the making of payments and transfers for current international transactions.

\section{Article IV Consultation:}

Cambodia is subject to the provisions on consultation cycles approved on July 15, 2002. The Executive Board concluded the last Article IV consultation on February 20, 2003.

\section{Technical Assistance:}

Following discussions between the Government, the IMF, UNDP, and other interested multilateral and bilateral donors, a comprehensive Technical Cooperation Action Plan (TCAP) was adopted in May 2001. The TCAP arrangement ended in mid-2004, following a six-month extension. Fund's technical assistance to Cambodia remains intensive, but will be gradually phased out (Annex VI). A resident Treasury Advisor was assigned in June 2004 for a period of 6 months. An FAD review mission will take place in October 2004 to review overall progress with revenue administration reforms and assist the authorities in defining the overall framework for future reforms in this area.

\section{Resident Representative:}

The resident representative office was closed in October 1997, but it was re-opened at endOctober 1999. Mr. Hagemann is currently the Resident Representative. 


\section{Cambodia: Debt Sustainability}

1. Under the staff's baseline scenario, Cambodia's debt is expected to be sustainable. ${ }^{1}$ The baseline scenario assumes sustained real GDP growth of 6 percent, export growth of 9 percent, and broadly stable foreign aid in nominal U.S. dollars. On the fiscal front, budgetary consolidation is expected to begin with the 2004 budget, which would require discretionary tax revenue measures and improvements in tax and customs administration.

\section{A. The Current Situation}

2. Cambodia's total external public debt was $\$ 3.0$ billion (71 percent of GDP) at end-2003, of which \$1.9 billion was owed to the United States and the Russian Federation. Other external debts were owed largely to multilateral creditors on highly concessional terms. Domestic public debt, all denominated in local currency, accounted for about 5 percent of GDP.

\section{Restructuring Cambodia's debts to the United States and the Russian}

Federation in highly concessional terms, which together account for 64 percent of total external debt, is critical for securing debt sustainability. The baseline scenario assumes that agreement is reached with the U.S. by mid-2004 on comparable terms to the 1995 Paris Club agreement (i.e., flow rescheduling on Naples terms). It assumes a 40-year maturity, a 16-year grace period, and an interest rate of 3 percent. Similar terms are assumed on the debt owed to the Russian Federation, after an initial upfront discount of 70 percent. The restructured debt would amount to $\$ 1.7$ billion at the end of 2004 . The total stock of outstanding debt at the end of 2004 would amount to $\$ 2.1$ billion (46 percent of GDP), or 29 percent of GDP in net present value (NPV) terms.

\section{B. Public Debt Sustainability}

4. Cambodia's stock of public debt is projected to decline after an initial increase from 34 percent of GDP in 2004 to 35 percent of GDP in 2006 in NPV terms. In the baseline scenario, total public sector debt in NPV terms is expected to fall to 16 percent by 2023 if the primary deficit is kept to about $2 \frac{1}{2} 2$ percent of GDP over the medium term and to about 3 percent of GDP in the longer run. The NPV of the debt-to-revenue ratio at 237 percent in 2004 is high, reflecting the weak revenue base. Hence, failure to improve revenue collection steadily over time would undermine public debt sustainability.

\footnotetext{
${ }^{1}$ Standard Fund templates for low income countries and sensitivity tests are used to assess Cambodia's debt dynamics. Tests involve applying temporary deviations of key variables from the baseline with magnitudes based largely on historical deviations.
} 
5. Sensitivity tests suggest that the debt dynamics are vulnerable to a real depreciation, to debt-creating flows in the medium term, and to lower GDP growth in the long term. A one-time 30 percent real depreciation in 2004 (test B5) would increase the NPV of the debt-to-GDP ratio from 34 percent of GDP in the baseline to over 50 percent of GDP, and the NPV of the debt-to-revenue ratio to more than 300 percent in the medium term. A 10 percent of GDP increase in debt-creating flows in the first projected year (test B6), such as might arise from an unexpected realization of contingent liabilities, would increase the NPV of the debt-to-GDP and debt-to-revenue ratios to 40 percent and 270 percent, respectively. If the real GDP growth rate were to fall by two standard deviations from its recent average (test B4), which corresponds broadly to the difference between the GDP growth shown in the non-adjustment scenario and the baseline presented in the main text (see paragraph 14), the NPV of the debt-to-revenue ratio would reach about 240 percent in the medium term.

\section{External Debt Sustainability}

6. In the baseline scenario, all debt indicators are projected to improve over time. The NPV of the debt-to-GDP ratios are expected to fall below 20 percent, the NPV of the debt-to-exports ratios to fall below 30 percent and the debt service-to-exports ratio would decline to below 2 percent in the long run.

\section{The debt dynamics are most vulnerable to a real depreciation and export}

decline. A one-time 30 percent real depreciation would push up the NPV of the debt-to-GDP ratio to about 45 percent in the near term. A one-time two standard deviation shock in exports, which is about twice as large as the shock assumed in the non-adjustment scenario in the main text, would raise the debt service-to-exports ratio to 4.8 percent compared with 3.4 percent in the baseline scenario, and the NPV of the debt-to-exports ratio would rise to 91 percent compared with 58 percent in the baseline scenario in 2013. Even then, these ratios are not high enough to threaten external viability.

\section{Conclusion}

8. The key vulnerability in Cambodia's debt dynamics is its weak fiscal revenue base. While the nominal stock of debt and service payments are modest relative to GDP, the revenue base, currently at 11 percent of GDP, may pose difficulties in servicing debt. A one-time real depreciation is also a source of risk as it increases the size of the stock of debt relative to GDP and fiscal revenue. 
Table 1. Cambodia: Public Sector Debt Sustainability Framework, Baseline Scenario, 2000-2023

(In percent of GDP, unless otherwise indicated)

\begin{tabular}{|c|c|c|c|c|c|c|c|c|c|c|c|c|c|c|c|}
\hline & \multicolumn{3}{|c|}{ Actual } & \multirow[b]{2}{*}{$\begin{array}{l}\text { Historical } \\
\text { Average 5/ }\end{array}$} & \multirow[b]{2}{*}{$\begin{array}{l}\text { Standard } \\
\text { Deviation 5/ }\end{array}$} & \multicolumn{5}{|l|}{ Estimate } & \multicolumn{5}{|c|}{ Projections } \\
\hline & 2000 & 2001 & 2002 & & & 2003 & 2004 & 2005 & 2006 & 2007 & 2008 & $\begin{array}{l}2003-08 \\
\text { Average }\end{array}$ & 2013 & 2023 & $\begin{array}{l}2009-23 \\
\text { Average }\end{array}$ \\
\hline $\begin{array}{l}\text { Public sector debt } 1 / \\
\text { o/w foreign-currency denominated }\end{array}$ & $\begin{array}{l}68.8 \\
66.8\end{array}$ & $\begin{array}{l}69.0 \\
67.2\end{array}$ & $\begin{array}{l}72.2 \\
68.4\end{array}$ & & & $\begin{array}{l}75.3 \\
70.8\end{array}$ & $\begin{array}{l}51.1 \\
46.3\end{array}$ & $\begin{array}{l}52.3 \\
48.3\end{array}$ & $\begin{array}{l}53.2 \\
49.9\end{array}$ & $\begin{array}{l}52.2 \\
49.7\end{array}$ & $\begin{array}{l}50.6 \\
48.9\end{array}$ & & $\begin{array}{l}41.0 \\
39.9\end{array}$ & $\begin{array}{l}22.7 \\
21.7\end{array}$ & \\
\hline Change in public sector debt & -0.6 & 0.2 & 3.2 & & & 3.1 & -24.3 & 1.2 & 0.9 & -1.0 & -1.6 & & -2.0 & -1.8 & \\
\hline Identified debt-creating flows & 4.5 & -0.1 & 0.5 & & & 1.6 & -23.0 & 2.0 & 0.7 & -0.4 & -0.7 & & -0.2 & 1.7 & \\
\hline Primary deficit & 2.0 & 2.7 & 3.6 & 2.0 & 1.2 & 4.3 & 3.2 & 3.1 & 3.1 & 2.7 & 2.5 & 3.1 & 2.5 & 3.3 & 2.8 \\
\hline Revenue and grants & 13.2 & 13.5 & 14.1 & & & 12.9 & 14.2 & 14.6 & 15.1 & 15.3 & 15.5 & & 15.2 & 14.5 & \\
\hline of which: grants & 2.8 & 2.7 & 2.9 & & & 2.5 & 2.2 & 2.3 & 2.2 & 2.0 & 1.8 & & 1.2 & 0.5 & \\
\hline Primary (noninterest) expenditure & 15.2 & 16.1 & 17.7 & & & 17.2 & 17.4 & 17.7 & 18.1 & 18.0 & 17.9 & & 17.8 & 17.8 & \\
\hline Automatic debt dynamics & -0.8 & -3.5 & -4.2 & & & -3.7 & -4.8 & -1.1 & -2.4 & -3.0 & -3.2 & & -2.8 & -1.6 & \\
\hline Contribution from interest rate/growth differential & -5.7 & -5.0 & -4.4 & & & -4.5 & -3.2 & -1.0 & -2.4 & -3.0 & -3.2 & & -2.7 & -1.6 & \\
\hline of which: contribution from average real interest rate & -1.2 & -1.3 & -0.8 & & & -0.9 & -0.1 & -0.1 & -0.2 & -0.3 & -0.3 & & -0.3 & -0.2 & \\
\hline of which: contribution from real GDP growth & -4.6 & -3.7 & -3.6 & & & -3.6 & -3.1 & -0.9 & -2.2 & -2.8 & -2.9 & & -2.4 & -1.4 & \\
\hline Contribution from real exchange rate depreciation & 4.9 & 1.5 & 0.2 & & & 0.7 & -1.6 & -0.1 & 0.0 & 0.0 & 0.0 & & 0.0 & 0.0 & \\
\hline Other identified debt-creating flows & 3.3 & 0.7 & 1.1 & & & 1.0 & -21.4 & 0.0 & 0.0 & 0.0 & 0.0 & & 0.0 & 0.0 & \\
\hline Privatization receipts (negative) & 0.0 & 0.0 & 0.0 & & & 0.0 & 0.0 & 0.0 & 0.0 & 0.0 & 0.0 & & 0.0 & 0.0 & \\
\hline Recognition of implicit or contingent liabilities & 0.0 & 0.0 & 0.0 & & & 0.0 & 0.0 & 0.0 & 0.0 & 0.0 & 0.0 & & 0.0 & 0.0 & \\
\hline Debt relief (HIPC and other) & 3.3 & 0.7 & 1.1 & & & 1.0 & -21.4 & 0.0 & 0.0 & 0.0 & 0.0 & & 0.0 & 0.0 & \\
\hline Bank recapitalization & 0.0 & 0.0 & 0.0 & & & 0.0 & 0.0 & 0.0 & 0.0 & 0.0 & 0.0 & & 0.0 & 0.0 & \\
\hline Residual, including asset changes & -5.1 & 0.4 & 2.7 & & & 1.5 & -1.3 & -0.7 & 0.2 & -0.6 & -0.8 & & -1.8 & -3.5 & \\
\hline NPV of public sector debt & 58.9 & 59.9 & 62.1 & & & 63.9 & 33.5 & 34.2 & 34.8 & 34.8 & 33.5 & & 26.9 & 16.4 & \\
\hline $\mathrm{o} / \mathrm{w}$ foreign-currency denominated & 56.9 & 58.0 & 58.2 & & & 59.4 & 28.8 & 30.2 & 31.5 & 32.3 & 31.7 & & 25.9 & 15.4 & \\
\hline $\mathrm{o} / \mathrm{w}$ external & 56.9 & 58.0 & 58.2 & & & 59.4 & 28.8 & 30.2 & 31.5 & 32.3 & 31.7 & & 25.9 & 15.4 & \\
\hline NPV of contingent liabilities (not yet officially recognized in public sector & $\ldots$ & $\ldots$ & $\ldots$ & & & $\ldots$ & $\ldots$ & $\ldots$ & $\ldots$ & $\ldots$ & $\ldots$ & & $\ldots$ & $\ldots$ & \\
\hline Gross financing need $2 /$ & 2.3 & 3.2 & 4.1 & & & 5.0 & 4.4 & 4.3 & 4.3 & 4.0 & 3.9 & & 4.1 & 4.1 & \\
\hline $\mathrm{NPV}$ of public sector debt-to-revenue ratio (in percent) $3 /$ & 446.0 & 445.1 & 439.4 & & & 495.8 & 236.5 & 233.7 & 231.3 & 227.7 & 216.3 & & 176.8 & 113.3 & \\
\hline $\mathrm{o} / \mathrm{w}$ external & 431.1 & 431.2 & 412.2 & & & 460.9 & 203.0 & 206.2 & 209.1 & 211.1 & 205.0 & & 169.9 & 106.1 & \\
\hline Debt service-to-revenue ratio (in percent) $3 / 4 /$ & 2.6 & 3.8 & 3.7 & & & 5.1 & 8.8 & 8.3 & 8.4 & 8.7 & 9.3 & & 10.0 & 6.1 & \\
\hline Primary deficit that stabilizes the debt-to-GDP ratio & 2.6 & 2.4 & 0.4 & & & 1.2 & 6.1 & 1.8 & 2.2 & 3.6 & 4.1 & & 4.6 & 5.1 & \\
\hline \multicolumn{16}{|l|}{ Key macroeconomic and fiscal assumptions } \\
\hline Real GDP growth (in percent) & 7.0 & 5.7 & 5.5 & 6.5 & 2.7 & 5.2 & 4.3 & 1.9 & 4.3 & 5.5 & 5.9 & 4.5 & 6.0 & 6.0 & 6.0 \\
\hline Average nominal interest rate on forex debt (in percent) & 0.3 & 0.3 & 0.3 & 0.3 & 0.0 & 0.4 & 0.8 & 1.6 & 1.6 & 1.5 & 1.5 & 1.2 & 1.4 & 1.3 & 1.3 \\
\hline Real exchange rate depreciation (in percent, + indicates depreciation) & 7.7 & 2.5 & 0.3 & 1.5 & 3.8 & 1.1 & -2.4 & -0.2 & 0.0 & 0.0 & 0.0 & -0.2 & -0.1 & -0.1 & -0.1 \\
\hline Inflation rate (GDP deflator, in percent) & -1.7 & -0.3 & 2.1 & 3.0 & 5.7 & 1.6 & 2.0 & 2.9 & 2.5 & 2.9 & 3.0 & 2.5 & 3.0 & 3.0 & 3.0 \\
\hline Growth of real primary spending (deflated by GDP deflator, in percent) & 17.0 & 12.2 & 16.0 & 14.1 & 2.7 & 2.0 & 5.3 & 4.0 & 6.7 & 4.5 & 5.7 & 4.7 & 6.0 & 6.0 & 5.9 \\
\hline Major commodity price & 0.0 & 0.0 & 0.0 & 0.0 & 0.0 & 0.0 & 0.0 & 0.0 & 0.0 & 0.0 & 0.0 & 0.0 & 0.0 & 0.0 & 0.0 \\
\hline Grant element of new external borrowing (in percent) & $\ldots$ & $\ldots$ & $\ldots$ & $\ldots$ & $\ldots$ & 49.3 & 47.6 & 48.8 & 48.0 & 49.2 & 50.1 & 48.8 & 51.3 & 51.0 & 51.1 \\
\hline
\end{tabular}

Sources: Country authorities; and Fund staff estimates and projections.

/ General government gross debt

2/ Gross financing need is defined as the primary deficit plus debt service plus the stock of short-term debt at the end of the last period.

$3 /$ Revenues including grants.

4/ Debt service is defined as the sum of interest and amortization of medium and long-term debt.

$5 /$ Historical averages and standard deviations are derived over the past 5 years. 


Baseline
A. Alternative scenarios
A1. Real GDP growth and primary balance are at historical averages
A2. Primary balance is unchanged from 2003
B. Bound tests
B1. Real GDP growth is at baseline minus two standard deviations in 2005
B2. Primary balance is at baseline minus one standard deviations in 2004-2005
B3. Combination of 2-3 using one half standard deviation shocks
B4. Long-run real GDP growth is at baseline minus two standard deviations
B5. One time 30 percent real depreciation in 2004
B6. 10 percent of GDP increase in other debt-creating flows in 2004

NPV of Debt-to-Revenue Ratio 1/

Baseline

\begin{tabular}{|c|c|c|c|c|c|c|c|}
\hline 64 & 34 & 34 & 35 & 35 & 33 & 27 & 16 \\
\hline 64 & 33 & 32 & 32 & 32 & 31 & 26 & 14 \\
\hline 64 & 34 & 35 & 37 & 37 & 37 & 34 & 26 \\
\hline 64 & 34 & 36 & 37 & 38 & 37 & 31 & 22 \\
\hline 64 & 34 & 35 & 36 & 36 & 34 & 28 & 17 \\
\hline 64 & 34 & 36 & 36 & 36 & 35 & 28 & 16 \\
\hline 64 & 34 & 35 & 37 & 37 & 37 & 34 & 36 \\
\hline 64 & 58 & 57 & 56 & 54 & 51 & 38 & 23 \\
\hline 64 & 39 & 39 & 40 & 40 & 38 & 31 & 18 \\
\hline 496 & 237 & 234 & 231 & 228 & 216 & 177 & 113 \\
\hline 496 & 232 & 221 & 215 & 212 & 202 & 172 & 94 \\
\hline 496 & 241 & 242 & 243 & 245 & 238 & 226 & 181 \\
\hline 496 & 237 & 247 & 247 & 245 & 236 & 205 & 154 \\
\hline 496 & 240 & 240 & 237 & 234 & 222 & 181 & 116 \\
\hline 496 & 241 & 242 & 239 & 235 & 222 & 180 & 113 \\
\hline 496 & 239 & 240 & 241 & 242 & 235 & 224 & 244 \\
\hline 496 & 406 & 389 & 370 & 354 & 330 & 252 & 157 \\
\hline 496 & 274 & 269 & 265 & 259 & 246 & 201 & 127 \\
\hline
\end{tabular}

A. Alternative scenarios

A1. Real GDP growth and primary balance are at historical averages

A2. Primary balance is unchanged from 2003

B. Bound tests

B1. Real GDP growth is at baseline minus two standard deviations in 2005

B2. Primary balance is at baseline minus one standard deviations in 2004-2005

B3. Combination of 2-3 using one half standard deviation shocks

B4. Long-run real GDP growth is at baseline minus two standard deviations

B5. One time 30 percent real depreciation in 2004

B6. 10 percent of GDP increase in other debt-creating flows in 2004

\section{Debt-to-GDP Ratio}

Baseline

A. Alternative scenarios

A1. Real GDP growth and primary balance are at historical averages

A2. Primary balance is unchanged from 2003

B. Bound tests

B1. Real GDP growth is at baseline minus two standard deviations in 2005

B2. Primary balance is at baseline minus one standard deviations in 2004-2005

B3. Combination of 2-3 using one half standard deviation shocks

B4. Long-run real GDP growth is at baseline minus two standard deviations

B5. One time 30 percent real depreciation in 2004

B6. 10 percent of GDP increase in other debt-creating flows in 2004

Debt Service-to-Revenue Ratio 1/

Baseline

A. Alternative scenarios

A1. Real GDP growth and primary balance are at historical averages

A2. Primary balance is unchanged from 2003

B. Bound tests

B1. Real GDP growth is at baseline minus two standard deviations in 2005

B2. Primary balance is at baseline minus one standard deviations in 2004-2005

B3. Combination of 2-3 using one half standard deviation shocks

B4. Long-run real GDP growth is at baseline minus two standard deviations

B5. One time 30 percent real depreciation in 2004

B6. 10 percent of GDP increase in other debt-creating flows in 2004

Debt Service-to-GDP Ratio

Baseline

$\begin{array}{llllllll}0.7 & 1.3 & 1.2 & 1.3 & 1.3 & 1.4 & \mathbf{1 . 5} & 0.9 \\ & & & & & & & \\ 0.7 & 1.2 & 1.1 & 1.2 & 1.2 & 1.3 & \mathbf{1 . 5} & 0.8 \\ 0.7 & 1.3 & 1.2 & 1.3 & 1.4 & 1.6 & \mathbf{1 . 8} & 1.4 \\ & & & & & & & \\ 0.7 & 1.3 & 1.3 & 1.3 & 1.4 & 1.6 & \mathbf{1 . 7} & 1.2 \\ 0.7 & 1.3 & 1.2 & 1.3 & 1.4 & 1.5 & \mathbf{1 . 5} & 0.9 \\ 0.7 & 1.3 & 1.3 & 1.3 & 1.4 & 1.5 & \mathbf{1 . 6} & 0.9 \\ 0.7 & 1.3 & 1.2 & 1.3 & 1.4 & 1.6 & \mathbf{1 . 8} & 1.7 \\ 0.7 & 1.4 & 1.6 & 1.6 & 1.7 & 1.8 & \mathbf{1 . 8} & 1.1 \\ 0.7 & 1.3 & 1.5 & 1.5 & 1.5 & 1.6 & \mathbf{1 . 8} & 1.0 \\ & & & & & & & \end{array}$

A. Alternative scenarios

A1. Real GDP growth and primary balance are at historical averages

A2. Primary balance is unchanged from 2003

B. Bound tests

B1. Real GDP growth is at baseline minus two standard deviations in 2005

B2. Primary balance is at baseline minus one standard deviations in 2004-2005

B3. Combination of 2-3 using one half standard deviation shocks

B4. Long-run real GDP growth is at baseline minus two standard deviations

B5. One time 30 percent real depreciation in 2004

B6. 10 percent of GDP increase in other debt-creating flows in 2004

$\begin{array}{llllllll}75 & 51 & 52 & 53 & 52 & 51 & \mathbf{4 1} & 23 \\ & & & & & & & \\ 75 & 50 & 49 & 49 & 48 & 47 & \mathbf{4 0} & 17 \\ 75 & 52 & 55 & 57 & 57 & 57 & \mathbf{5 4} & 39 \\ & & & & & & & \\ 75 & 51 & 56 & 57 & 57 & 56 & \mathbf{4 8} & 32 \\ 75 & 52 & 54 & 55 & 54 & 52 & \mathbf{4 2} & 23 \\ 75 & 52 & 54 & 55 & 54 & 52 & \mathbf{4 2} & 22 \\ 75 & 52 & 54 & 56 & 56 & 56 & \mathbf{5 4} & 55 \\ 75 & 84 & 84 & 83 & 81 & 77 & \mathbf{6 0} & 33 \\ 75 & 61 & 62 & 63 & 61 & 59 & \mathbf{4 7} & 26\end{array}$

Sources: Country authorities; and Fund staff estimates and projections.

1/ Revenues are defined inclusive of grants.

CInternational Monetary Fund. Not for Redistribution 
Table 3. Cambodia: External Debt Sustainability Framework, Baseline Scenario, 2000-2023 1/ (In percent of GDP, unless otherwise indicated)

\begin{tabular}{|c|c|c|c|c|c|c|c|c|c|c|c|c|c|c|c|}
\hline & \multicolumn{3}{|c|}{ Actual } & \multirow{2}{*}{$\begin{array}{l}\text { Historical } \\
\text { Average 6/ }\end{array}$} & \multirow{2}{*}{$\begin{array}{l}\text { Standard } \\
\text { Deviation 6/ }\end{array}$} & \multirow{2}{*}{$\begin{array}{r}\text { Estimate } \\
2003\end{array}$} & \multirow[b]{2}{*}{2004} & \multirow[b]{2}{*}{2005} & \multicolumn{3}{|c|}{ Projections } & \multirow[b]{2}{*}{$\begin{array}{l}2003-08 \\
\text { Average }\end{array}$} & \multirow[b]{2}{*}{2013} & \multirow[b]{2}{*}{2023} & \multirow[b]{2}{*}{$\begin{array}{l}2009-23 \\
\text { Average }\end{array}$} \\
\hline & 2000 & 2001 & 2002 & & & & & & 2006 & 2007 & 2008 & & & & \\
\hline External debt (nominal) 1/ & 66.8 & 67.2 & 68.4 & & & 70.8 & 46.3 & 48.3 & 49.9 & 49.7 & 48.9 & & 39.9 & 21.7 & \\
\hline $\mathrm{o} / \mathrm{w}$ public and publicly guaranteed (PPG) & 66.8 & 67.2 & 68.4 & & & 70.8 & 46.3 & 48.3 & 49.9 & 49.7 & 48.9 & & 39.9 & 21.7 & \\
\hline Identified net debt-creating flows & -3.7 & -4.8 & -7.2 & & & -2.8 & -1.3 & 1.6 & 0.3 & -0.8 & -1.5 & & -2.4 & -2.5 & \\
\hline Non-interest current account deficit & 2.5 & 0.8 & 0.8 & 2.9 & 2.2 & 2.0 & 2.8 & 3.4 & 3.4 & 3.0 & 2.6 & & 1.7 & 1.7 & 1.8 \\
\hline Deficit in balance of goods and services & 29.5 & 27.8 & 27.9 & & & 31.6 & 32.3 & 29.6 & 28.5 & 27.4 & 26.4 & & 22.2 & 18.4 & \\
\hline Exports & 33.8 & 38.1 & 39.2 & & & 40.1 & 42.1 & 39.7 & 39.6 & 40.0 & 40.7 & & 44.7 & 54.3 & \\
\hline Imports & 63.3 & 65.9 & 67.2 & & & 71.7 & 74.5 & 69.3 & 68.0 & 67.4 & 67.1 & & 66.9 & 72.7 & \\
\hline Net current transfers (negative $=$ inflow) & -12.8 & -11.9 & -11.5 & -11.3 & 1.3 & -11.7 & -11.3 & -11.1 & -10.7 & -10.3 & -9.8 & & -6.8 & -3.0 & -5.6 \\
\hline Net FDI (negative $=$ inflow) & -4.0 & -3.8 & -3.5 & -5.0 & 1.7 & -1.8 & -1.8 & -1.8 & -1.8 & -1.9 & -2.1 & & -2.3 & -3.1 & -2.5 \\
\hline Endogenous debt dynamics $2 /$ & -2.2 & -1.8 & -4.5 & & & -2.9 & -2.2 & -0.1 & -1.3 & -1.8 & -2.0 & & -1.8 & -1.0 & \\
\hline Contribution from nominal interest rate & 0.4 & 0.4 & 0.4 & & & 0.4 & 0.6 & 0.7 & 0.7 & 0.7 & 0.7 & & 0.5 & 0.3 & \\
\hline Contribution from real GDP growth & -4.5 & -3.7 & -3.4 & & & -3.4 & -2.8 & -0.8 & -2.0 & -2.5 & -2.7 & & -2.3 & -1.3 & \\
\hline Contribution from price and exchange rate changes & 1.9 & 1.4 & -1.5 & & & & & & & & & & $\ldots$ & & \\
\hline Residual (3-4) 3/ & 3.3 & 5.2 & 8.4 & & & 5.3 & -23.2 & 0.4 & 1.3 & 0.6 & 0.7 & & 0.4 & 0.7 & \\
\hline $\mathrm{o} / \mathrm{w}$ exceptional financing & 3.3 & 0.7 & 1.1 & & & 1.0 & -21.4 & 0.0 & 0.0 & 0.0 & 0.0 & & 0.0 & 0.0 & \\
\hline NPV of external debt $4 /$ & 56.9 & 58.0 & 58.2 & & & 59.4 & 28.8 & 30.2 & 31.5 & 32.3 & 31.7 & & 25.9 & 15.4 & \\
\hline In percent of exports $9 /$ & 168.6 & 152.5 & 148.4 & & & 148.0 & 68.3 & 76.1 & 79.6 & 80.7 & 78.0 & & 57.9 & 28.3 & \\
\hline NPV of PPG external debt & 56.9 & 58.0 & 58.2 & & & 59.4 & 28.8 & 30.2 & 31.5 & 32.3 & 31.7 & & 25.9 & 15.4 & \\
\hline In percent of exports $9 /$ & 168.6 & 152.5 & 148.4 & & & 148.0 & 68.3 & 76.1 & 79.6 & 80.7 & 78.0 & & 57.9 & 28.3 & \\
\hline Total gross financing need (billions of U.S. dollars) & 0.1 & -0.1 & 0.0 & & & 0.1 & 0.1 & 0.1 & 0.1 & 0.1 & 0.1 & & 0.1 & -0.1 & \\
\hline Non-interest current account deficit that stabilizes debt ratio $8 /$ & 2.9 & 0.5 & -0.4 & & & -0.5 & 5.9 & 1.5 & 1.8 & 3.1 & 3.4 & & 3.7 & 3.5 & \\
\hline \multicolumn{16}{|l|}{ Key macroeconomic assumptions } \\
\hline Real GDP growth (in percent) & 7.0 & 5.7 & 5.5 & 6.5 & 2.7 & 5.2 & 4.3 & 1.9 & 4.3 & 5.5 & 5.9 & 4.5 & 6.0 & 6.0 & 6.0 \\
\hline GDP deflator in US dollar terms (change in percent) & -2.8 & -2.1 & 2.3 & -0.4 & 2.4 & 0.0 & 2.7 & 3.0 & 1.6 & 2.2 & 2.0 & 1.9 & 2.1 & 2.1 & 2.1 \\
\hline Effective interest rate (percent) $5 /$ & 0.6 & 0.6 & 0.7 & 0.6 & 0.0 & 0.7 & 0.9 & 1.6 & 1.6 & 1.5 & 1.5 & 1.3 & 1.4 & 1.2 & 1.3 \\
\hline Growth of exports of G\&S (US dollar terms, in percent) & 25.1 & 16.6 & 11.3 & 23.6 & 13.2 & 7.6 & 12.4 & -1.1 & 5.6 & 9.0 & 9.8 & 7.2 & 10.4 & 10.5 & 10.4 \\
\hline Growth of imports of G\&S (US dollar terms, in percent) & 20.4 & 7.7 & 10.1 & 18.5 & 12.8 & 12.3 & 11.2 & -2.4 & 4.0 & 6.8 & 7.5 & 6.6 & 8.7 & 9.5 & 8.8 \\
\hline Grant element of new public sector borrowing (in percent) & $\ldots$ & $\ldots$ & $\ldots$ & $\ldots$ & $\ldots$ & 49.3 & 47.6 & 48.8 & 48.0 & 49.2 & 50.1 & 48.8 & 51.3 & 51.0 & 51.1 \\
\hline \multicolumn{16}{|l|}{ Memorandum item: } \\
\hline Nominal GDP (billions of US dollars) & 3.6 & 3.7 & 4.0 & & & 4.2 & 4.5 & 4.7 & 5.0 & 5.4 & 5.8 & & 8.7 & 19.2 & \\
\hline
\end{tabular}

Source: Staff simulations.

$1 /$ Includes both public and private sector external debt.

2/ Derived as $[\mathrm{r}-\mathrm{g}-\rho(1+\mathrm{g})](1+\mathrm{g}+\rho+\mathrm{g} \rho)$ times previous period debt ratio, with $\mathrm{r}=$ nominal interest rate; $\mathrm{g}=$ real GDP growth rate, and $\rho=$ growth rate of GDP deflator in U.S. dollar terms.

3/ Includes exceptional financing (i.e., changes in arrears and debt relief); changes in gross foreign assets; and valuation adjustments. For projections also includes contribution from price and exchange rate change.

$5 /$ Current-year interest payments divided by previous period debt stock.

6/ Historical averages and standard deviations are generally derived over the past 5 years.

7/ Debt-services before 2003 are cash basis.

$8 /$ Debt forgiveness in 2004 is excluded

9/Excluding garment-related imports and re-exportable imports 


\begin{tabular}{|c|c|c|c|c|c|c|c|c|}
\hline & \multirow{2}{*}{$\begin{array}{r}\text { Estimate } \\
2003\end{array}$} & \multicolumn{7}{|c|}{ Projections } \\
\hline & & 2004 & 2005 & 2006 & 2007 & 2008 & 2013 & 2023 \\
\hline \multicolumn{9}{|c|}{ NPV of debt-to-GDP ratio } \\
\hline Baseline & 59 & 29 & 30 & 31 & 32 & 32 & 26 & 15 \\
\hline \multicolumn{9}{|l|}{ A. Alternative Scenarios } \\
\hline A1. Key variables at their historical averages in 2004-23 1/ & 59 & 28 & 27 & 26 & 26 & 25 & 18 & 10 \\
\hline A2. New public sector loans on less favorable terms in 2004-23 2/ & 59 & 30 & 32 & 35 & 36 & 36 & 33 & 23 \\
\hline \multicolumn{9}{|l|}{ B. Bound Tests } \\
\hline B1. Real GDP growth at baseline minus two standard deviation in 2005 & 59 & 29 & 32 & 33 & 34 & 33 & 27 & 16 \\
\hline B2. Export value growth at baseline minus two standard deviation in 2005 3/ & 59 & 29 & 35 & 37 & 37 & 37 & 30 & 17 \\
\hline B3. US dollar GDP deflator at historical average minus one standard deviation in 2004-05 & 59 & 30 & 34 & 35 & 36 & 36 & 29 & 17 \\
\hline B4. Net non-debt creating flows at historical average minus one standard deviation in 2004-05 4/ & 59 & 29 & 30 & 31 & 32 & 31 & 26 & 15 \\
\hline B5. Combination of B1-B4 using one-half standard deviation shocks & 59 & 29 & 27 & 28 & 29 & 29 & 24 & 15 \\
\hline B6. One-time 30 percent nominal depreciation relative to the baseline in 2004 5/ & 59 & 41 & 43 & 44 & 46 & 45 & 37 & 22 \\
\hline
\end{tabular}

\section{NPV of debt-to-exports ratio}

\section{Baseline}

\section{A. Alternative Scenarios}

A1. Key variables at their historical averages in 2004-23 1/

A2. New public sector loans on less favorable terms in 2004-23 2/

\section{B. Bound Tests}

B1. Real GDP growth at baseline minus two standard deviation in 2005

B2. Export value growth at baseline minus two standard deviation in 2005 3/

B3. US dollar GDP deflator at historical average minus one standard deviation in 2004-05

B4. Net non-debt creating flows at historical average minus one standard deviation in 2004-05 4/

B5. Combination of B1-B4 using one-half standard deviation shocks

B6. One-time 30 percent nominal depreciation relative to the baseline in 20045

$\begin{array}{rrrrrrrr}148 & 68 & 76 & 80 & 81 & 78 & \mathbf{5 8} & 28 \\ & & & & & & & \\ 148 & 66 & 68 & 67 & 65 & 61 & \mathbf{4 0} & 18 \\ 148 & 71 & 82 & 88 & 91 & 90 & \mathbf{7 3} & 42 \\ & & & & & & & \\ & & & & & & & \\ 148 & 68 & 76 & 80 & 81 & 78 & \mathbf{5 8} & 28 \\ 148 & 68 & 122 & 126 & 127 & 122 & \mathbf{9 1} & 42 \\ 148 & 68 & 76 & 80 & 81 & 78 & \mathbf{5 8} & 28 \\ 148 & 68 & 75 & 79 & 80 & 77 & \mathbf{5 7} & 28 \\ 148 & 65 & 53 & 56 & 57 & 55 & \mathbf{4 1} & 21 \\ 148 & 68 & 76 & 80 & 81 & 78 & \mathbf{5 8} & 28\end{array}$

\section{Debt service ratio}

\section{Baseline}

\section{A. Alternative Scenarios}

A1. Key variables at their historical averages in 2004-23 1/

A2. New public sector loans on less favorable terms in 2004-23 2

\section{B. Bound Tests}

B1. Real GDP growth at baseline minus two standard deviation in 2005

B2. Export value growth at baseline minus two standard deviation in 2005 3/

B3. US dollar GDP deflator at historical average minus one standard deviation in 2004-05

B4. Net non-debt creating flows at historical average minus one standard deviation in 2004-05 4/

B5. Combination of B1-B4 using one-half standard deviation shocks

B6. One-time 30 percent nominal depreciation relative to the baseline in 20045 /

Memorandum item:

Grant element assumed on residual financing (i.e., financing required above baseline) 6 /

$\begin{array}{llllllll}1.7 & 2.9 & 3.1 & 3.1 & 3.3 & 3.5 & \mathbf{3 . 4} & 1.6 \\ & & & & & & & \\ 1.7 & 2.9 & 3.0 & 2.9 & 3.1 & 3.4 & \mathbf{3 . 3} & 1.1 \\ 1.7 & 2.9 & 3.2 & 3.4 & 3.8 & 4.2 & \mathbf{4 . 3} & 2.5\end{array}$

$\begin{array}{llllllll}1.7 & 2.9 & 3.1 & 3.1 & 3.3 & 3.5 & \mathbf{3 . 4} & 1.6 \\ 1.7 & 2.9 & 4.2 & 4.5 & 4.7 & 5.1 & \mathbf{4 . 8} & 2.6 \\ 1.7 & 2.9 & 3.1 & 3.1 & 3.3 & 3.5 & \mathbf{3 . 4} & 1.6 \\ 1.7 & 2.9 & 3.1 & 3.0 & 3.2 & 3.5 & \mathbf{3 . 4} & 1.6 \\ 1.7 & 2.7 & 2.5 & 2.3 & 2.5 & 2.7 & \mathbf{2 . 6} & 1.2 \\ 1.7 & 2.9 & 3.1 & 3.1 & 3.3 & 3.5 & \mathbf{3 . 4} & 1.6\end{array}$

$\begin{array}{llllllll}50 & 50 & 50 & 50 & 50 & 50 & \mathbf{5 0} & 50\end{array}$

Source: Staff projections and simulations.

1/ Variables include real GDP growth, growth of GDP deflator (in U.S. dollar terms), non-interest current account in percent of GDP, and non-debt creating flows

2/ Assumes that the interest rate on new borrowing is by 2 percentage points higher than in the baseline., while grace and maturity periods are the same as in the baseline.

3/ Exports values are assumed to remain permanently at the lower level, but the current account as a share of GDP is assumed to return to its baseline level after the shock (implicitly assuming an offsetting adjustment in import levels).

4/ Includes official and private transfers and FDI.

5/ Depreciation is defined as percentage decline in dollar/local currency rate, such that it never exceeds 100 percent.

6/ Applies to all stress scenarios except for A2 (less favorable financing) in which the terms on all new financing are as specified in footnote 2 . 
Figure 1. Cambodia: Indicators of Public Debt Under Alternative Scenarios, 2003-2023 1/

(In percent)

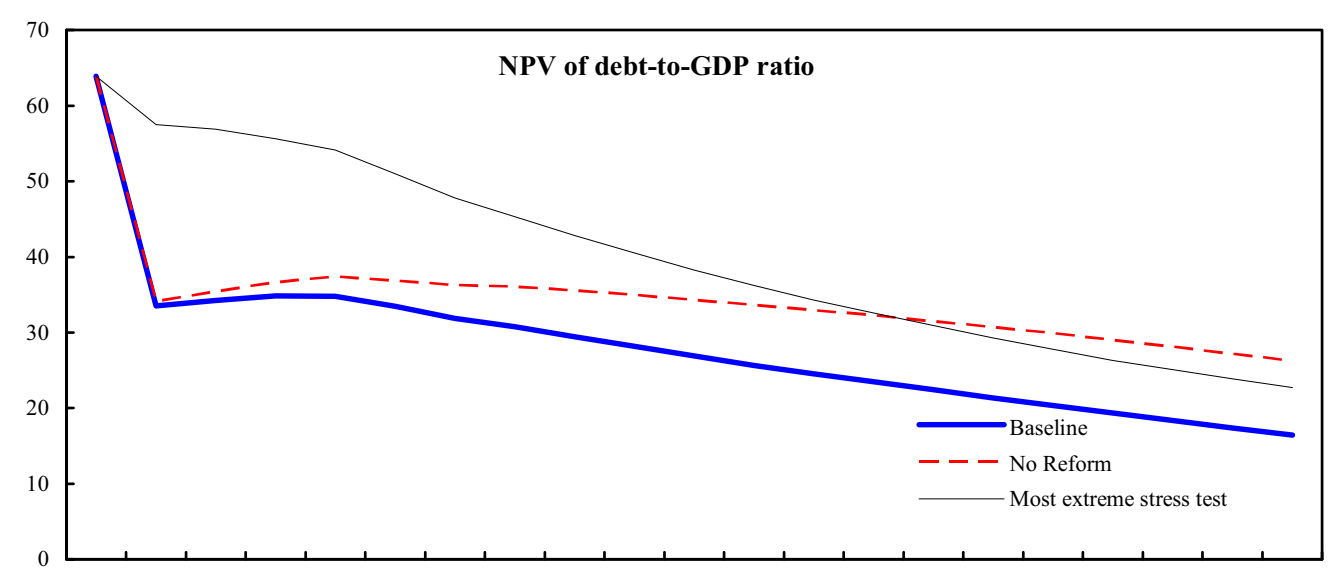

200320042005200620072008200920102011201220132014201520162017201820192020202120222023
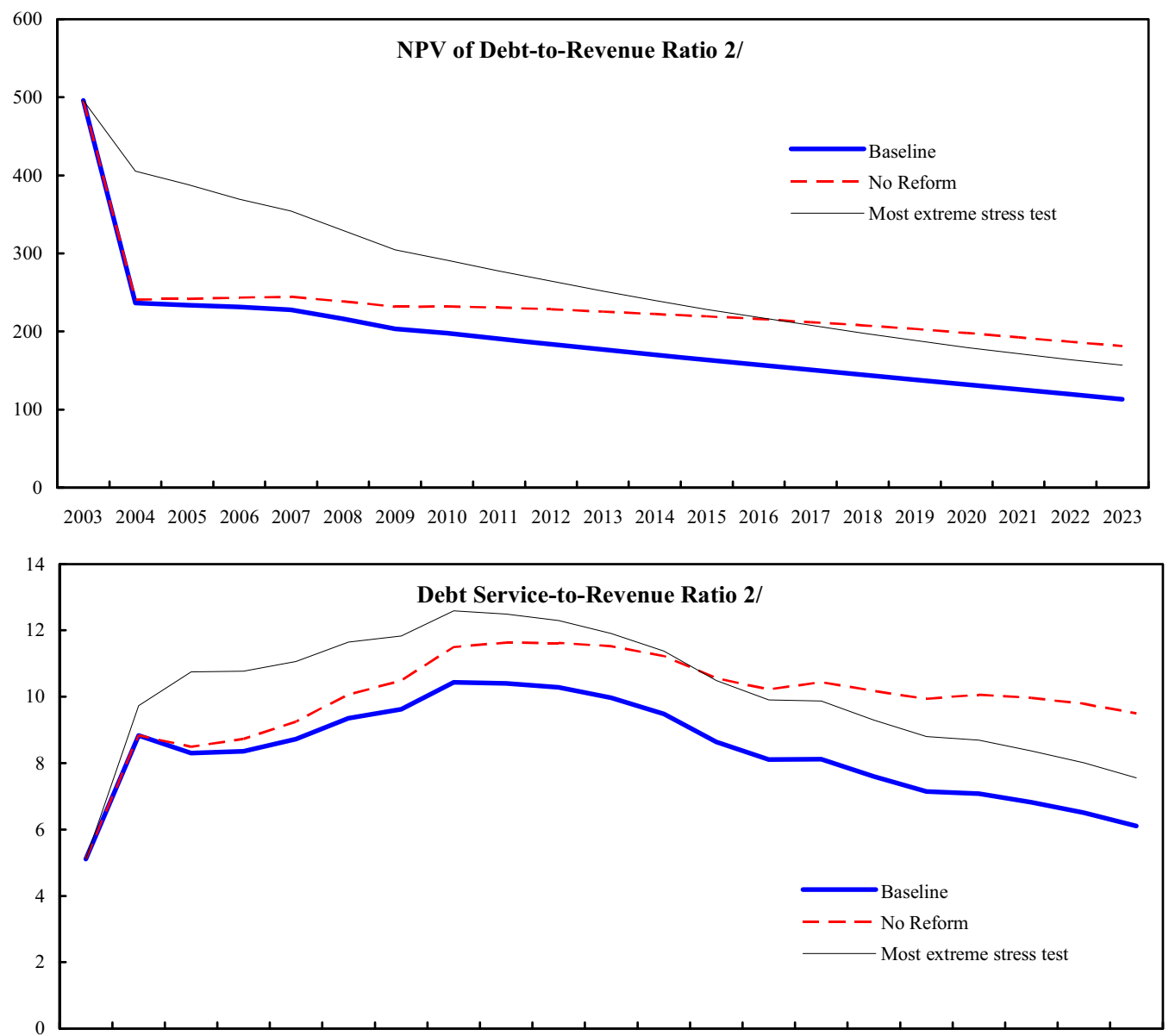

200320042005200620072008200920102011201220132014201520162017201820192020202120222023

Source: Staff projections and simulations.

1/ Most extreme stress test is test that yields highest ratio in 2013.

2/ Revenue including grants. 
Figure 2. Cambodia: Indicators of Public and Publicly Guaranteed External Debt Under Alternative Scenarios, 2003-2023

(In percent)

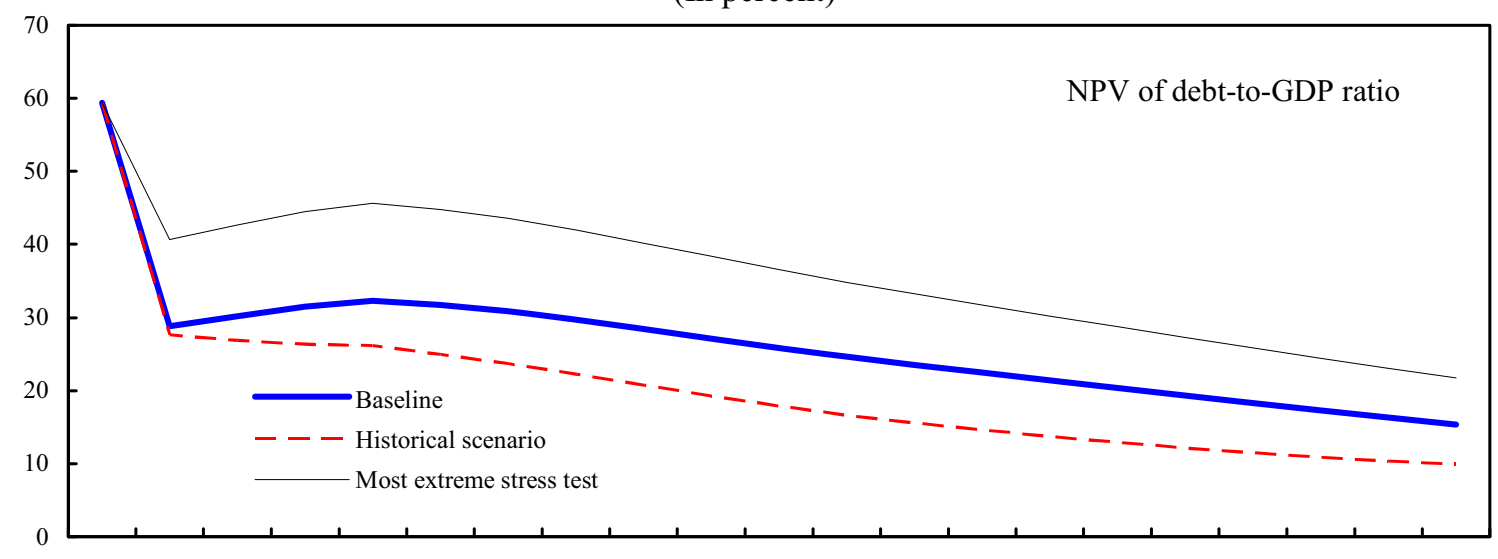

200320042005200620072008200920102011201220132014201520162017201820192020202120222023

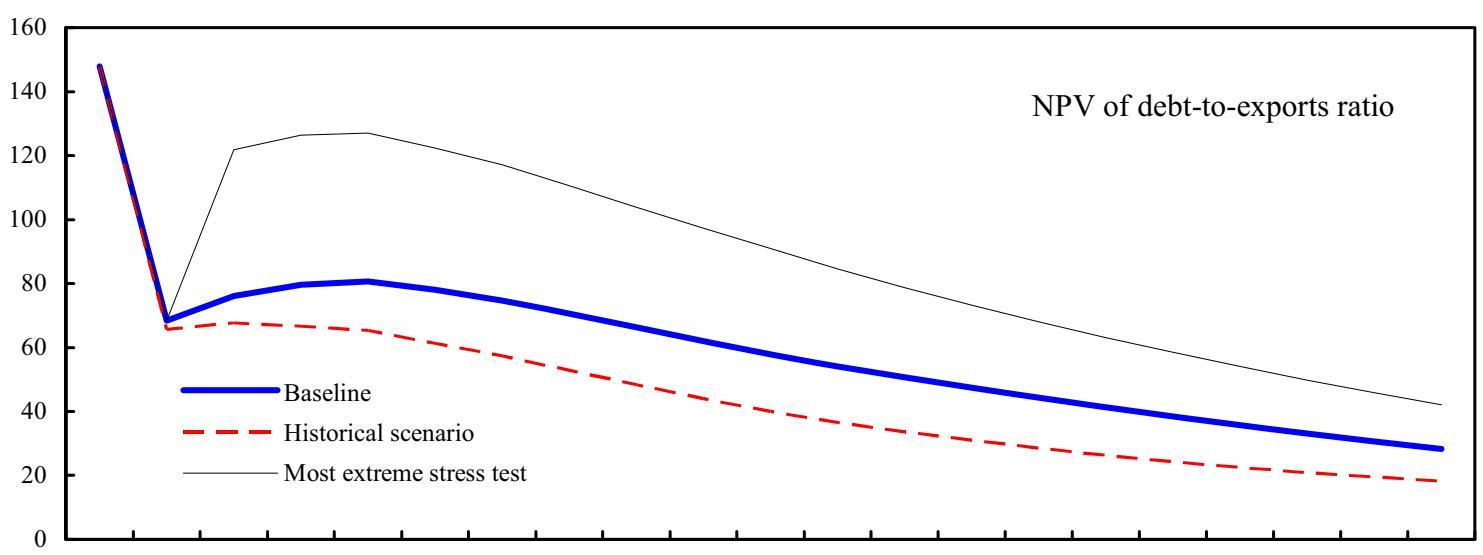

200320042005200620072008200920102011201220132014201520162017201820192020202120222023

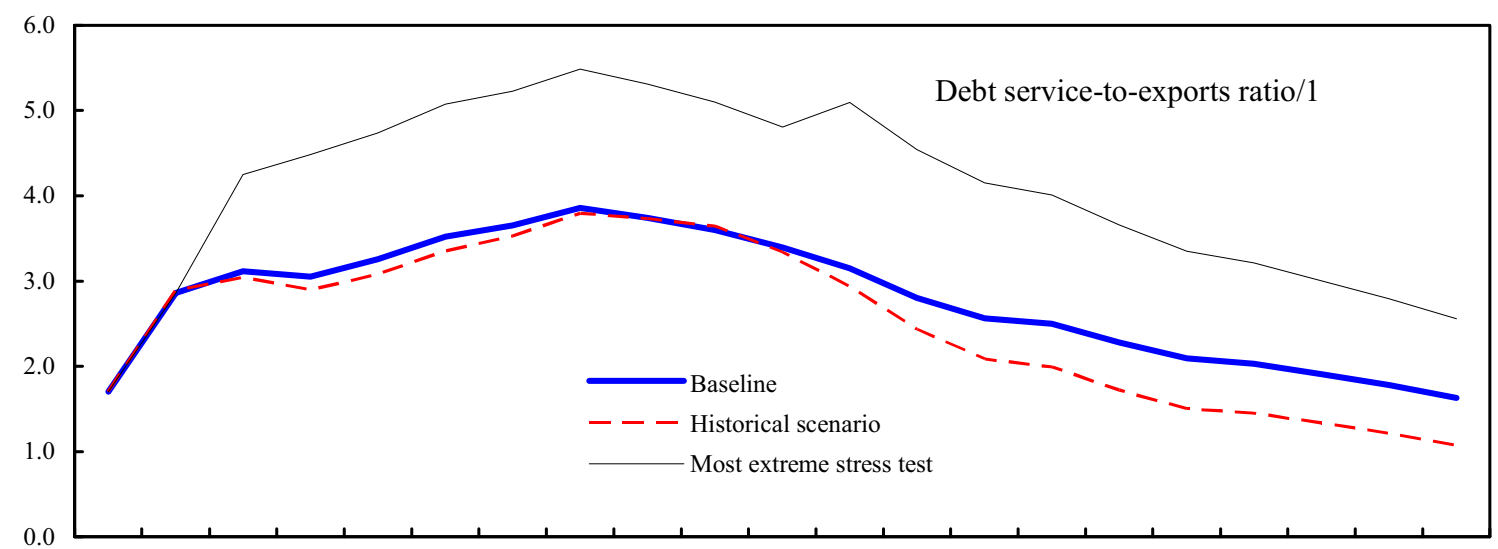

200320042005200620072008200920102011201220132014201520162017201820192020202120222023

Source: Staff projections and simulations.

1/ Debt service in 2003 is cash basis. The difference between cash and accrual basis comes from arrears for the U.S. and the Russian Federation. 


\section{Cambodia: World Bank Policy Dialogue and Its Relation with the IMF ${ }^{1}$}

The World Bank's policy dialogue in Cambodia covers public financial management, private sector development, legal and judicial reform, military demobilization, the national poverty reduction strategy, rural development, decentralization, the national transportation strategy, governance and anti-corruption, and forestry management. The pace of the Bank's dialogue has been affected by delays in forming a government since the July 2003 elections.

\section{National Poverty Reduction Strategy (NPRS)}

Following completion of the NPRS in December 2002, the JSA was presented to the Board in February 2003, and highlights a number of strengths and challenges/weaknesses, some of which the government, with the Bank support, has worked to address. The Bank provided technical assistance (TA) and financial support to the General Secretariat of the Council for Social Development (GSCSD) in the Ministry of Planning (MoP) under an IDF grant, and has also mobilized a multi-donor trust fund to continue this support and supported the wide dissemination of the NPRS at local levels. The TA has focused on coordinating inputs from donors and government on the annual progress report (APR) for the NPRS, and specifically on updating the policy action matrix and integrating the NPRS and the Cambodian Millenium Development Goals (CMDG) indicators into one monitoring framework. The WB/IMF have consolidated comments on two drafts of the APR to the government and prepared a joint JSA.

The Bank is assisting in the design of the NPRS architecture, a roadmap for implementing the NPRS and developing the government's next five year strategy (2006-2010). As part of this process, the Bank has been convening informal donor meetings to discuss the restructuring of the Technical Working Groups (TWGs) and planning an inclusive participatory process for producing the National Poverty Assessment (NPA) 2005, which will combine the results (Poverty Profile) of the current Cambodian Socio-Economic Survey (CSES) (which the Bank is supporting along with UNDP and SIDA), as well as participatory, qualitative poverty assessments currently being undertaken by ADB and WB. The NPA will aim to ensure broadbased buy-in from all stakeholders and form the analytical basis for the next five year plan.

The NPRS process has been challenging from the start, and most recently due to delayed formation of the government. In addition, there has been confusion as to the respective roles of MOP and MEF in the NPRS process. As a result the Bank has not been able to proceed with a formal dialogue regarding the NPRS architecture and the National Poverty Assessment, but these will be taken up with the new government.

Other Poverty and Gender Initiatives. The Bank is coordinating a multi-stakeholder PSIA on Social Land Concessions as key policy reform issue, and is preparing a Land Allocation for Social and Economic Development project. The Bank has recently completed a Country Gender Assessment (in collaboration with ADB/UNDP/UNIFEM). The Bank has provided an

\footnotetext{
${ }^{1}$ Contact person on this note: Mr. Rob Taliercio, World Bank (473-0071)
} 
IDF grant to the Ministry of Women's and Veterans' Affairs (MoWVA) for building capacity for gender policy analysis and gender budgeting.

Public Financial Management. The Government and some partners have worked to prioritize reforms to the public expenditure and financial management system following Technical Cooperation Assistance Program (TCAP) and the joint WB-ADB Integrated Fiduciary Assessment and Public Expenditure Review, 2003 (IFAPER). A joint effort of ten of Cambodia's development partners committed in January 2004 to assist in strengthening the Government's ability to lead and implement this agenda and to provide fully coordinated support via a sector wide approach (SWAp). The collaborative approach is supported by the Public Expenditure and Financial Accountability (PEFA) secretariat, as envisioned in the recent Bank-Fund board paper. ${ }^{2}$ It is expected that the Government will develop a prioritized, sequenced, and costed annual PFM work program (on a rolling basis) over the new few months with implementation starting in August 2004 or so.

The IFAPER, which is the basis for the Bank's engagement in this sector, found that though Cambodia has made significant headway in reforming public expenditure policy and management, it will have to make much more progress on three principal fiscal, fiduciary, and institutional challenges in order to implement its development agenda. Indeed, in comparative perspective, Cambodia's PFM system ranks below average (as compared to the low income countries assessed by a joint World Bank-IMF diagnostic tool), indicating the need for substantial upgrading. (move this paragraph first).

Civil Service Reform. The IFAPER found serious problems afflicting the civil service-low pay, pay compression, low skills, and thus low capacity. Low public sector wages provide a breeding ground for corrupt practices and low pay is a leading cause of Cambodia's relatively poor standing on public sector performance. The World Bank's CPIA ranks Cambodia in the fourth lowest quintile among fellow low income countries on issues pertaining to public sector management and institutions. Though the Government has recently made some progress, including an increase in average remuneration in 2002, carrying out of a civil service census, and the development of an automated payroll system, much more is required. In some of these areas, such as workforce control, key measures such as the introduction of an establishment register will allow the Government to build productively on its previous successes, while in other areas, notably pay and employment policy, the Government will be challenged to push itself farther and faster than currently envisioned. Decompression of salaries coupled with average salary increases is a key element of the Government's reform program.

The Bank has provided the Government with a significant amount of grant funding to carry out an agreed set of studies that would provide the analytical groundwork for reform. These studies cover: (i) labor market pay comparator analysis, (ii) pay and employment sustainability

2 “Bank/Fund Collaboration on Public Expenditure Issues," February 14, 2003. 
analysis, (iii) reallocation and retrenchment analysis, (iv) development of a functional analysis methodology and its application to select ministries, and (v) preparation of an establishment register. Work on the studies has only recently commenced and is thus far behind schedule.

Private Sector Development. While there is broad appreciation for efforts to improve the foreign investment regime, develop a pro-poor trade strategy, and create a Private Sector Forum to facilitate a reform dialogue with the private sector, the Government needs to place a higher priority on structural reforms to support sustainable, private-led growth. The Bank, working with the MPDF, IFC and PPIAF, has provided an input to the Government's Private Sector Development Strategy through an Investment Climate Assessment and Value Chain Analysis. The objective of this effort is three-fold: to remove impediments to productivity growth, to help diversify the economy, and to increase the role of the private sector in service delivery. The findings of the work to date have identified overlapping trade facilitation, inspection, and licensing processes of various agencies as contributing to an excessive regulatory burden and a high incidence of corruption associated with the Cambodian investment climate. In light of these findings, the Bank is focusing its efforts on operationalizing the reform recommendations through a potential SWAp on private sector development. Initial focus areas for the SWAp are trade facilitation, inspection mandates, reform of PPI governance arrangements, and value chain development.

Legal and Judicial Reform, Governance, and Anti-Corruption. With support from the Bank, the Government devised a Legal and Judicial Reform (LJR) Strategy in 2002 that was formally adopted in June 2003 and published an ambitious draft Plan of Action. This plan was then the subject of a Government-sponsored National LJR Workshop in December 2003. Various follow-up working groups have proposed action plan interventions that are now being prioritized with a view to fixing a sequenced work program for the remainder of 2004 and beyond with emphasis on: (a) access to legal and judicial services and the collection and dissemination of relevant legal and judicial information; (b) empowering the market economy and legal and judicial reforms in support of private sector development; and (c) the creation and support of alternative dispute resolution mechanisms.

Both external and internal perception-based surveys indicate high levels of corruption in Cambodia. The 2001 Governance Action Plan (GAP) was seen as a road map to guide a comprehensive reform of governance in Cambodia. The GAP covered five cross-cutting issues: legal and judiciary system, public administration, decentralization and deconcentration, public finance, anti-corruption and gender issues, and two sectoral areas of special focus, armed services reform and natural resource management (land, forestry and fisheries). The NPRS notes that the GAP was a comprehensive and ambitious program and that "controlling and eliminating corrupt practices is a long term and difficult process." While some ground work has been done in many areas, it has not as yet amounted to significant action that shifts the incentives in a way that discourages corrupt behavior.

The Bank's new Country Assistance Strategy (CAS) will focus on four key cross-cutting areas that have strong linkages to a governance agenda: (i) improved public financial management and public administration reform, (ii) private sector development, (iii) improved local 
governance and accountability, and (iv) improved access of the poor to productive assets. To be included in the Bank's assistance program, interventions will need to support reforms and results in at least one of these four areas.

Military Demobilization. The first phase of the full-scale demobilization program was completed early 2003 with the distribution of the reintegration packages to 15,000 demobilized soldiers. At the same time, the second phase was postponed for various reasons including the proximity of elections, and an investigation by Bank's Institutional Integrity Unit. In June 2003, the Bank declared misprocurement on a contract for $\$ 6.9$ million resulting in the cancellation of $\$ 6.3$ million from the IDA credit, and a further $\$ 0.6$ million from a Dutch Grant. A total of almost $\$ 2.8$ million dollars is required to be repaid by the government to the Special Account. The Government has postponed the next phase of the Demobilization program since early 2003. Discussions on the future of the program will take place once the new government has been formed. If a decision is made to continue with the program, and with the IDA funding, several outstanding areas of concern including the inflated payroll lists, and the project design, will need to be addressed.

Transportation Sector Strategy. Despite significant diagnostic work and investment in reconstruction and development of infrastructure, transport remains a constraint to overall as well as equitable growth. There is no agreed transport sector strategy and Cambodia's management of its considerable transport assets remains poor. The transport sector strategy note, originally developed with the ADB's support, is currently being updated with Bank support and will take stock of the current state of the sector, including the Government's views and priorities, the areas of engagement of other donors, the views of transport users, consultant assessments and the like. The resulting note will serve as input to the joint CAS process, suggest possible avenues for Bank and other donor engagement in the sector over the next 3 to 5 years. This informal note will be completed before the end of the current FY.

\section{World Bank-IMF Collaboration}

Bank-Fund collaboration in Cambodia takes place at two levels: (i) through the policy-based lending program; and (ii) through analytical and advisory services. It is expected that there will be close coordination between the Fund's upcoming PRGF program and the Bank's proposed PRSC. The first PRSC is likely to focus on public financial management and private sector development (and subsequent PRSCs would broaden the coverage to priority sectors). It is expected that the Bank and Fund will work under streamlined conditionality arrangements. Lending operations and non-lending instruments are described in the following tables. The Bank's current portfolio grew from 10 to 18 credits over the previous CAS period, rising from US\$245 million to \$364 million, supporting a sectorally and geographically diverse set of projects. Disbursement levels have been above the average for the region. The new CAS is expected to go to the Board in January 2005. 


\section{World Bank's Main Non-Lending Services: Issues and Instruments}

(Recently completed and ongoing, as of July 2004)

\begin{tabular}{|c|c|}
\hline Issue & Instrument \\
\hline Civil Service Reform & $\begin{array}{l}\text { IFAPER (2003), PHRD grant on public sector reform (ongoing), IDF } \\
\text { grant on civil service reform (ongoing), and pay and employment study } \\
\text { on the education sector (to be completed in 2005). }\end{array}$ \\
\hline Environment & $\begin{array}{l}\text { Cambodia Environment Monitor (2003), Phase II Cambodia, Lao PDR } \\
\text { and Vietnam Poverty-Environment Nexus Study (ongoing). }\end{array}$ \\
\hline Gender & $\begin{array}{l}\text { Cambodia Gender Assessment (April 2004), and IDF grant on gender } \\
\text { (ongoing). }\end{array}$ \\
\hline Governance & $\begin{array}{l}\text { Governance and Corruption Diagnostic Report (2001), IDF grant on } \\
\text { governance (2002), and PHRD grant on public sector reform (ongoing). }\end{array}$ \\
\hline Human Development & $\begin{array}{l}\text { PSIA on evaluating conditional means-tested school subsidies (ongoing), } \\
\text { "Quality Basic Education for All" study on determinants of schooling } \\
\text { participation (ongoing), and PHRD grant on social sector reform } \\
\text { (ongoing). }\end{array}$ \\
\hline Legal and Judicial Reform & Justice for the Poor study (to be completed by early 2005) \\
\hline $\begin{array}{l}\text { Poverty Reduction and } \\
\text { Economics }\end{array}$ & $\begin{array}{l}\text { Poverty Assessment (2000), PRSP/JSA (February 2003), APR/JSA } \\
\text { (September 2004), IDF grant on poverty reduction (completed 2003), } \\
\text { Poverty Reduction Strategy Trust Funds (ongoing), Sources of Growth } \\
\text { (to be completed by mid-2005), Moving out of Poverty study (to be } \\
\text { completed in late 2005), National Poverty Assessment (to be completed } \\
\text { in late 2005), and PSIA on WTO Accession (to be completed by early } \\
\text { 2005). }\end{array}$ \\
\hline $\begin{array}{l}\text { Private Sector } \\
\text { Development and Trade }\end{array}$ & $\begin{array}{l}\text { FIAS report on FDI (2001), Integration and Competitiveness Study } \\
\text { (2002), Seizing the Global Opportunity: Investment Climate Assessment } \\
\text { and Reform Strategy (June 2003), and PPIAF grant to develop an } \\
\text { interim regulatory framework (ongoing). }\end{array}$ \\
\hline $\begin{array}{l}\text { Public Financial } \\
\text { Management }\end{array}$ & $\begin{array}{l}\text { IFAPER (2003), Policy and Human Resource Development (PHRD) } \\
\text { grant on public sector reform (ongoing), Country Procurement } \\
\text { Assessment Report (2004), Public Expenditure Tracking Survey- } \\
\text { Education (to be completed by mid-2005), and IDF grant to assist with } \\
\text { development of private sector accounting capacity. }\end{array}$ \\
\hline Rural and Agriculture & $\begin{array}{l}\text { Rice Value Chain Study (2002), PSIA on social land concessions } \\
\text { (2004), Rural Sector Strategy (2004). }\end{array}$ \\
\hline
\end{tabular}


IDA: Commitments and Disbursements to Cambodia (In millions of dollars, as of July 8, 2004)

\begin{tabular}{|c|c|c|c|}
\hline Project & Effective Date & Committed & Disbursed \\
\hline \multicolumn{4}{|l|}{ Credits: } \\
\hline Emergency Rehabilitation Project [Closed] & January 13, 1994 & 62.70 & 62.70 \\
\hline Technical Assistance Project [Closed] & March 23, 1995 & 17.00 & 17.00 \\
\hline Economic Rehabilitation Credit Project [Closed] & December 18,1995 & 40.00 & 40.00 \\
\hline Phnom Penh Power Rehabilitation Project [Closed] & December 20, 1995 & 40.00 & 40.00 \\
\hline Social Fund Project [Closed] & December 21, 1995 & 20.00 & 20.00 \\
\hline Urban Water Supply Project & June 2, 1998 & 30.96 & 30.88 \\
\hline Road Rehabilitation Project & June 14, 1999 & 45.31 & 32.69 \\
\hline Social Fund Project (02) & July 7, 1999 & 25.00 & 24.84 \\
\hline Northeast Village Development Project & November 11, 1999 & 5.00 & 4.85 \\
\hline Education Quality Improvement Project & December 20, 1999 & 5.00 & 4.10 \\
\hline Structural Adjustment Credit Project [Closed] & March 28, 2000 & 30.00 & 30.00 \\
\hline Biodiversity \& Protected Area Project & May 3, 2000 & 1.91 & 0.80 \\
\hline Forest Concession Management and Control Pilot Project & October 20,2000 & 4.82 & 2.62 \\
\hline Flood Emergency Rehabilitation Project & June 4, 2001 & 35.00 & 28.21 \\
\hline Social Fund Project (02) & September 27, 2001 & 10.00 & 9.69 \\
\hline Land Management and Administration Project & June 19, 2002 & 24.30 & 0.61 \\
\hline Demobilization and Reintegration Project & July 1,2002 & 18.40 & 7.69 \\
\hline Economic and Public Sector Capacity Building Project & February 10, 2003 & 5.50 & -0.72 \\
\hline Health Sector Support Project & August 14, 2003 & 17.20 & 0.21 \\
\hline Rural Investment and Local Governance Project & September 16, 2003 & 22.00 & 2.57 \\
\hline Provincial and Peri-Urban Water and Sanitation Project & November 16, 2003 & 16.90 & -0.50 \\
\hline Provincial and Rural Infrastructure Project & March 16, 2004 & 20.00 & 0.30 \\
\hline Rural Electrification And Transmission [Approved] & & 40.00 & -1.09 \\
\hline \multicolumn{2}{|l|}{ Total Credits } & 537.00 & 358.09 \\
\hline \multicolumn{4}{|l|}{ Grants: } \\
\hline Disease Control and Health Development [Refinanced] & July 4, 1996 & 1.50 & 1.50 \\
\hline Agriculture Productivity Improvement Project & June 20, 1997 & 27.00 & 20.71 \\
\hline Disease Control and Health Development [Closed] & June 23, 1997 & 30.40 & 30.40 \\
\hline Social Fund Project (02) & June 9, 1998 & 0.40 & 0.40 \\
\hline Road Rehabilitation Project & October 29, 1998 & 0.35 & 0.35 \\
\hline Demobilization and Reintegration Project [Closed] & August 17, 2000 & 0.35 & 0.35 \\
\hline Provincial and Rural Infrastructure Project [Refinanced] & July 6, 2001 & 0.21 & 0.21 \\
\hline Rural Electrification And Transmission Project & November 6, 2001 & 0.29 & 0.29 \\
\hline Provincial and Rural Infrastructure Project & September 9, 2002 & 0.11 & 0.11 \\
\hline Health Sector Support Project & August 14, 2003 & 7.80 & 0.65 \\
\hline Health Sector Support Project & August 14, 2003 & 2.00 & -0.14 \\
\hline Provincial and Peri-Urban Water and Sanitation Project & November 16, 2003 & 3.00 & -0.38 \\
\hline \multicolumn{2}{|l|}{ Total Grants } & 73.41 & 54.45 \\
\hline
\end{tabular}




\section{Cambodia: Relations with the Asian Development Bank}

From 1992 through June 2004, the Asian Development Bank (AsDB) approved \$773.6 million in low-interest loans to Cambodia to finance 26 projects and 5 structural reform programs. To date 10 projects, for a total of \$256.0 million, have been completed: (i) the Special Rehabilitation Assistance Project [approved in 1992];

(ii) Power Rehabilitation Project [approved in 1994]; (iii) Agriculture Sector Program [approved in 1996];

(iv) Basic Skills Project [approved in 1995]; (v) Rural Infrastructure Improvement Project [approved in 1995];

(vi) Basic Education Text Book Project (approved in 1996); (vii) Basic Health Services Project [approved in 1996]; (viii) Phnom Penh Water Supply and Drainage Project [approved in 1996]; (ix) Siem Reap Airport Project (approved in 1996); and (x) Financial Sector Program, Subprogram I [approved in 2001]. Of the remaining loan projects, $\$ 251.8$ million were for economic infrastructure, $\$ 107.0$ million for social infrastructure, and $\$ 118.81$ million for agriculture and rural infrastructure, and $\$ 40$ million for finance and governance.

During the same period, the AsDB also designed and administered 113 technical assistance projects amounting to $\$ 73.5$ million. They were financed through grants from the AsDB (\$27.4 million), the Japanese Special Fund (\$32.8 million), and other sources (\$13.3 million). In 2003, the AsDB approved five national loans: Agriculture Sector Development Program; Agriculture Sector Development Project; Northwest Irrigation Project; GMS Power Transmission; and Provincial Towns Improvement (Supplement).

The AsDB's draft Country Strategy and Program (CSP) for 2005-2009 has been developed in close collaboration with the World Bank and DFID and senior government officials at technical level. The draft CSP will focus on pro-poor sustainable growth, social development, and good governance. The AsDB will foster broad-based economic growth through investments in physical infrastructure, support for greater regional integration, sustainable development of small and medium-scale enterprises and investments in agriculture. It aims to improve the welfare and reduce vulnerability of the poor through increasing their access to physical assets, land, human capital and services. It's work on governance will concentrate on directly supporting improvements in public financial management, decentralization and deconcentration initiatives, and improving public service delivery. These will be accomplished through AsDB's program of assistance in the following four priority sectors: (i) agriculture and water resources; (ii) education; (iii) finance; and (iv) transport. The draft CSP has its geographical focus in the Tonle Sap Basin.

AsDB: Loan Commitments and Disbursements to Cambodia, 1992-2004

(In millions of U.S. dollars) as of June 30, 2004

\begin{tabular}{|c|c|c|c|}
\hline & Loan Approvals & $\begin{array}{c}\text { Contract Awards/ } \\
\text { Commitments }\end{array}$ & Disbursements \\
\hline 1992 & 67.7 & 0.0 & 0.0 \\
\hline 1993 & 0.0 & 4.4 & 5.4 \\
\hline 1994 & 28.2 & 35.9 & 12.2 \\
\hline 1995 & 45.1 & 28.1 & 35.9 \\
\hline 1996 & 105.0 & 15.3 & 32.1 \\
\hline 1997 & 0.0 & 41.5 & 10.7 \\
\hline 1998 & 40.0 & 29.1 & 29.3 \\
\hline 1999 & 88.0 & 17.0 & 26.2 \\
\hline 2000 & 109.6 & 114.2 & 50.8 \\
\hline 2001 & 75.2 & 40.7 & 48.3 \\
\hline 2002 & 116.5 & 64.4 & 78.9 \\
\hline 2003 & 98.3 & 62.0 & 73.3 \\
\hline 2004 (projected) & 45.0 & 83.4 & 103.2 \\
\hline Total & 818.6 & 536.0 & 506.3 \\
\hline
\end{tabular}




\section{Cambodia-Statistical Issues}

Extensive technical assistance from the Fund, the UNDP, the AsDB, and the World Bank has contributed to substantial improvements in macroeconomic statistics. Since October 2001, a long-term IMF advisor was placed in the National Institute of Statistics (NIS) to assist the authorities in upgrading economic and financial statistics. An expanded edition of the statistical yearbook was published in September 2003. An IFS page for Cambodia has been published since April 1996. In March 2002 Cambodia began participation in the Fund's General Data Dissemination System, and Cambodia's metadata were posted on the Dissemination Standards Bulletin Board. Despite significant shortcomings in some areas, core data are generally adequate for program design and monitoring and are provided on a timely basis.

National accounts. Official GDP estimates are provided annually under peripatetic expert support from the AsDB. Revised national accounts series for 1993-2002 were officially released in July 2003. The quality of GDP estimates remains hampered by the lack of comprehensive and reliable sectoral information. A National Accounts Concepts, Sources and Methods Manual was finalized and submitted for publication.

Prices. The NIS provides a monthly CPI with a five-week lag. NIS has recently updated the CPI for Phnom Penh with new expenditure weights (July-December, $2000=100)$. In addition, the NIS has compiled a quarterly urban CPI for five major provincial cities and Phnom Penh since July 2000. An ongoing project, financed by the AsDB and supported by STA, is developing a quarterly producer price index commencing in December 2003.

Government finance statistics. The Ministry of Economy and Finance provides monthly fiscal data broadly based on GFS standards on a timely basis with a four-week lag. There are still weaknesses regarding the reliability of data sources, the coverage and the economic and functional classifications of expenditure. Donor-specific data on investments financed by project are available only with considerable lags. Further improvements will require an increase in human resources devoted to government finance statistics compilation and will depend heavily on the ongoing measures to improve expenditure management, including a revision of public accounting.

The authorities have provided monthly fiscal data for publication in IFS since 2001 . The last reported data are for December 2002.

Monetary statistics. The NBC provides data on the monetary authorities and deposit money banks on a monthly basis with a four-week lag. An IMF mission in April 2002 assisted the authorities in strengthening the framework for compiling monetary statistics. In addition to the accounts of the monetary authorities and deposit money banks, the NBC also compiles the sectoral balance sheet for central bank and a central bank survey. It plans to compile a depository corporations survey in accordance with the methodology recommended in the IMF's Monetary and Financial Statistics Manual after all banks have fully implemented the uniform chart of accounts. 
External sector statistics. The NBC is responsible for compiling balance of payments statistics. Customs data have substantial coverage and valuation problems arising from the nonrecording of nondutiable imports, under reporting of re-exports, and the weakness of customs controls. While there have been improvements in the quality of foreign direct investment data, private capital flows are believed to be large and not fully captured by official data. A range of international transactions by enterprises, such as payments for imported services, income payments, and portfolio investment abroad are not included in the data. Data on external debt are provided by the Ministry of Economy and Finance, but timely information on disbursements by bilateral donors is weak. In January 2003, the authorities implemented an International Transactions Reporting System (ITRS) to collect data on international transactions via the banking system to improve balance of payments estimates. A balance of payments mission in March-May 2004 reviewed source data used for compiling the balance of payments and recommended improvements. 
Cambodia: Core Statistical Indicators as of July 27, 2004

\begin{tabular}{|c|c|c|c|c|c|c|c|c|c|c|c|c|}
\hline & $\begin{array}{l}\text { Exchange } \\
\text { Rates }\end{array}$ & $\begin{array}{l}\text { International } \\
\text { Reserves }^{1}\end{array}$ & $\begin{array}{l}\text { Central } \\
\text { Bank } \\
\text { Balance } \\
\text { Sheet }\end{array}$ & $\begin{array}{l}\text { Reserve/ } \\
\text { Base Money }\end{array}$ & $\begin{array}{l}\text { Broad } \\
\text { Money }\end{array}$ & $\begin{array}{l}\text { Interest } \\
\text { Rates }\end{array}$ & $\begin{array}{l}\text { Consumer } \\
\text { Price Index }\end{array}$ & $\begin{array}{l}\text { Exports/ } \\
\text { Imports }\end{array}$ & $\begin{array}{l}\text { Current } \\
\text { Account } \\
\text { Balance }\end{array}$ & $\begin{array}{l}\text { Overall } \\
\text { Government } \\
\text { Balance }^{2}\end{array}$ & GDP/GNP & $\begin{array}{l}\text { External } \\
\text { Public } \\
\text { Debt/Debt } \\
\text { Service }\end{array}$ \\
\hline $\begin{array}{l}\text { Date of Latest } \\
\text { Observation }\end{array}$ & Jul. 25 & Jun. 2004 & May 2004 & May 2004 & May 2004 & May 2004 & May 2004 & Mar. 2004 & Dec. 2003 & Dec. 2003 & \begin{tabular}{|l}
2003 \\
preliminary
\end{tabular} & Dec. 2003 \\
\hline Date Received & Jul. 6, 2004 & Jul. 6, 2004 & $\begin{array}{l}\text { Jul. } 6 \text {, } \\
2004\end{array}$ & Jul. 6, 2004 & $\begin{array}{l}\text { Jul. 6, } \\
2004\end{array}$ & $\begin{array}{l}\text { Jul. } 6 \text {, } \\
2004\end{array}$ & $\begin{array}{l}\text { Jul. 6, } \\
2004\end{array}$ & $\begin{array}{l}\text { Jul. 6, } \\
2004\end{array}$ & $\begin{array}{l}\text { May 11, } \\
2004\end{array}$ & $\begin{array}{l}\text { May 11, } \\
2004\end{array}$ & $\begin{array}{l}\text { May 11, } \\
2004\end{array}$ & $\begin{array}{l}\text { May 11, } \\
2004\end{array}$ \\
\hline $\begin{array}{l}\text { Frequency of } \\
\text { Data }\end{array}$ & Daily & Daily & Monthly & Weekly & Monthly & Monthly & Monthly & Quarterly & Quarterly & Monthly & Annual & Monthly \\
\hline $\begin{array}{l}\text { Frequency of } \\
\text { Reporting }\end{array}$ & $\begin{array}{l}\text { Daily } \\
\text { one-day lag }\end{array}$ & $\begin{array}{l}\text { Daily } \\
\text { one-day lag }\end{array}$ & $\begin{array}{l}\text { Monthly } \\
\text { five-week } \\
\text { lag }\end{array}$ & $\begin{array}{l}\text { Weekly one- } \\
\text { week lag }\end{array}$ & $\begin{array}{l}\text { Monthly } \\
\text { five-week } \\
\text { lag }\end{array}$ & $\begin{array}{l}\text { Monthly } \\
\text { five-week } \\
\text { lag }\end{array}$ & $\begin{array}{l}\text { Monthly } \\
\text { five-week } \\
\text { lag }\end{array}$ & $\begin{array}{l}\text { During } \\
\text { missions }\end{array}$ & $\begin{array}{l}\text { During } \\
\text { missions }\end{array}$ & $\begin{array}{l}\text { Monthly } \\
\text { one-month } \\
\text { lag }\end{array}$ & Annual & $\begin{array}{l}\text { Monthly } \\
\text { eight- } \\
\text { month lag }\end{array}$ \\
\hline Source of Data & NBC & $\mathrm{NBC}$ & NBC & $\mathrm{NBC}$ & $\mathrm{NBC}$ & NBC & NIS & NBC & NBC & MEF & NIS & MEF \\
\hline $\begin{array}{l}\text { Mode of } \\
\text { Reporting }\end{array}$ & Fax or Email & Fax or Email & $\begin{array}{l}\text { Fax or } \\
\text { Email }\end{array}$ & $\begin{array}{l}\text { Fax or } \\
\text { Email }\end{array}$ & $\begin{array}{l}\text { Fax or } \\
\text { Email }\end{array}$ & $\begin{array}{l}\text { Fax or } \\
\text { Email }\end{array}$ & $\begin{array}{l}\text { Fax or } \\
\text { Email }\end{array}$ & $\begin{array}{l}\text { Fax or } \\
\text { Email }\end{array}$ & $\begin{array}{l}\text { Fax or } \\
\text { Email }\end{array}$ & Fax & $\begin{array}{l}\text { During } \\
\text { missions }\end{array}$ & $\begin{array}{l}\text { Fax or } \\
\text { Email }\end{array}$ \\
\hline Confidentiality & No & Yes & No & No & No & No & No & No & No & No & No & Yes \\
\hline $\begin{array}{l}\text { Frequency of } \\
\text { Publication }\end{array}$ & Daily & N/A & Monthly & Monthly & Monthly & Monthly & Monthly & Annually & Annually & Annually & Annually & N/A \\
\hline
\end{tabular}

${ }^{1}$ Refers to gross and net international reserves.

${ }^{2}$ Refers to general government balance. 


\section{Cambodia-Summary of Technical Assistance Provided by the Fund, 1999-June 2004}

\begin{tabular}{|c|c|}
\hline Purpose & $\begin{array}{l}\text { Assistance and Timing } \\
\text { (person-months) }\end{array}$ \\
\hline 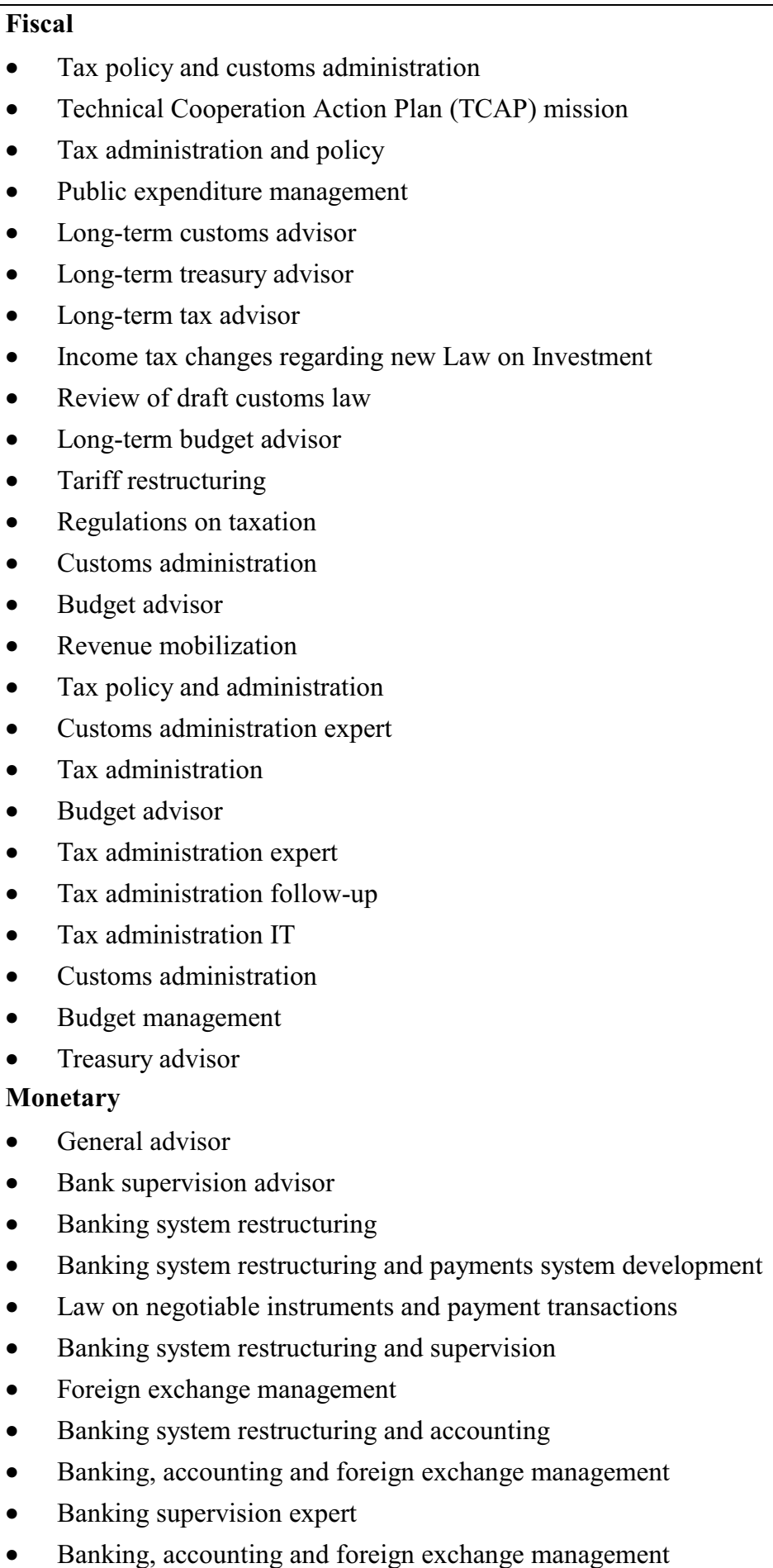 & $\begin{array}{l}\text { September 1999; (2) } \\
\text { March-April 2000; (33/4) } \\
\text { March 2001; (1) } \\
\text { April 2001; (1) } \\
\text { April 2001; (21) } \\
\text { August 2001; (14) } \\
\text { October 2001; (14) } \\
\text { April 2002; (1/2) } \\
\text { May 2002; }(1 / 4) \\
\text { August 2002; (6) } \\
\text { October 2002; (1) } \\
\text { November/December 2002; (3/4) } \\
\text { May 2003; (1/2) } \\
\text { July-August 2003; (1/2) } \\
\text { August/September 2003; (1) } \\
\text { August-October 2003; (3) } \\
\text { October-November/Dec. 2003 (1) } \\
\text { November 2003; (1/4) } \\
\text { December 2003; (7) } \\
\text { February 2004; (2) } \\
\text { February-March 2004; (1/2) } \\
\text { February 2004-February 2005 (4) } \\
\text { March 2004-January 2005 (4) } \\
\text { December 2003-June 2004 (6) } \\
\text { June-November 2004 (6) } \\
\text { 1999; (1) } \\
\text { 2000 - 2002; (1) } \\
\text { April 2001; (1) } \\
\text { August and November 2001; (2) } \\
\text { March and May 2002; (1/2) } \\
\text { July and December 2002; (2) } \\
\text { September 2002; (3/4) } \\
\text { January 2003; (1) } \\
\text { April 2003; (2) } \\
\text { November 2003; (6+12) } \\
\text { December 2003; (1) }\end{array}$ \\
\hline
\end{tabular}




\begin{tabular}{|c|c|}
\hline Purpose & $\begin{array}{l}\text { Assistance and Timing } \\
\text { (person-months) }\end{array}$ \\
\hline $\begin{array}{ll}- & \text { AML/CFT } \\
\text { - } & \text { Accounting } \\
\text { - } & \text { Mission on Central Bank internal audit }\end{array}$ & $\begin{array}{l}\text { December } 2003 ;(1 / 4) \\
\text { May 2004; }(1 / 2) \\
\text { June 2004; }(1)\end{array}$ \\
\hline $\begin{array}{l}\text { Statistics } \\
\text { - } \quad \text { Government finance statistics } \\
\text { - } \quad \text { Gong-term multisector statistics advisor } \\
\text { - } \quad \text { Monetary statistics } \\
\text { - } \quad \text { Balance of payments compilation expert } \\
\text { - } \quad \text { Balance of payments compilation expert } \\
\text { - } \quad \text { Producer price statistics } \\
\text { - } \quad \text { Consumer price index } \\
\text { - } \quad \text { GFS follow-up } \\
\text { - } \quad \text { Multisector statistics advisor } \\
\text { - Balance of payments statistics } \\
\text { Legal } \\
\text { - Insolvency Law } \\
\text { - Insolvency Law } \\
\text { - Insolvency Law } \\
\text { - AML/CFT } \\
\text { Finance } \\
\text { - Safeguards assessment }\end{array}$ & $\begin{array}{l}\text { April 2001; (1) } \\
\text { November 2001; (12) } \\
\text { November-December 2001; (1) } \\
\text { March-April 2002; (1) } \\
\text { April-June; Oct.-Nov. 2002; (6) } \\
\text { March-May 2003; (3) } \\
\text { July-August 2003; (1) } \\
\text { October 2003; (1/2) } \\
\text { December 2003; (1/2) } \\
\text { January 2004; (12) } \\
\text { March 2004; }(1 / 2) \\
\text { November 2000; }(1 / 2) \\
\text { July 2001; }(1 / 2) \\
\text { February and December 2002; (1) } \\
\text { December 2003; (1/4) } \\
\text { January 2004; }(3 / 4)\end{array}$ \\
\hline
\end{tabular}




\section{INTERNATIONAL MONETARY FUND}

\section{Public Information Notice}

EXTERNAL

RELATIONS DEPARTMENT

Public Information Notice (PIN) No. 04/108

FOR IMMEDIATE RELEASE

September 27, 2004
International Monetary Fund

$70019^{\text {th }}$ Street, NW

Washington, D. C. 20431 USA

\section{IMF Concludes 2004 Article IV Consultation with Cambodia}

On September, 13, 2004, the Executive Board of the International Monetary Fund (IMF) concluded the Article IV consultation with Cambodia. ${ }^{1}$

\section{Background}

Macroeconomic performance in the past few years was generally good, reflecting both favorable external developments and prudent fiscal policy. Annual real GDP growth averaged 6-7 percent. With the advent of political stability in 1999, private sector activities flourished in urban areas. Exports soared following a bilateral trade agreement with the U.S., and large aid inflows helped finance domestic investment and spurred construction activities. Prudent fiscal policy, including strengthened tax and customs administration, has also been key to ensuring price stability.

These favorable developments, however, have masked underlying structural weaknesses. Competitiveness has deteriorated on account of poor governance-in part due to lack of progress in legal and judicial reform - which exacerbated uncertainty in the business environment, while rudimentary infrastructure and high wages have kept operating costs high. Government capacity remains severely constrained by lack of human capital and entrenched governance problems. At the same time agricultural development has stagnated due to limited access to arable land and markets. Slow growth in agriculture, a sector where most of the poor make their living, has pushed Cambodia further away from meeting the Millenium Development Goals (MDGs).

\footnotetext{
${ }^{1}$ Under Article IV of the IMF's Articles of Agreement, the IMF holds bilateral discussions with members, usually every year. A staff team visits the country, collects economic and financial information, and discusses with officials the country's economic developments and policies. On return to headquarters, the staff prepares a report, which forms the basis for discussion by the Executive Board. At the conclusion of the discussion, the Managing Director, as Chairman of the Board, summarizes the views of Executive Directors, and this summary is transmitted to the country's authorities and this PIN summarizes the views of the Executive Board.
} 
In 2003, non-agricultural growth slowed due to the SARS-related drop in tourism and electionrelated uncertainties. Overall GDP growth, however, was robust mainly because of a strong rebound in agricultural production following a reduced harvest the previous year. Prices remained stable reflecting low trading partner inflation and prudent fiscal policy, although some of the earlier gains in fiscal revenue collection were lost in the election year, severely constraining priority spending.

The pace of reforms stalled in the run-up and aftermath of the July 2003 elections.

The government has recently produced an action plan to implement its strategy for legal and judicial reform, but not much has been done from this reform agenda in the last 10 years.

Reform of the Treasury slowed in 2003: about two thirds of line ministries still do not provide timely reports of their transactions to the Treasury, and there was yet another late-year bunching of spending commitments. The 2004 budget law, along with a range of legislation needed to complete WTO accession still await parliament approval.

Growth is expected to slow in 2004-2005. While tourism is rebounding, agricultural growth is expected to be lower than the exceptionally high growth rate of the previous year. A further slowdown, possibly to below 2 percent GDP growth, is expected as Cambodia will be exposed to direct competition from China following the elimination of the garment quota system in January 2005. It will take some time before Cambodia's exports could recover, even with accelerated reform implementation given the higher input costs and governance problems.

The Ex-Post Assessment of performance under previous Fund-supported programs noted that macroeconomic developments were generally good, but growth remained volatile and narrowly based. There was little progress in alleviating poverty and progress in improving governance, civil service reform, and demobilization was slow. As such, while quantitative targets presented no problems, compliance of structural conditionality under the Fund programs was mixed.

\section{Executive Board Assessment}

Executive Directors noted that Cambodia has made progress in rebuilding its economy from the ruins of the decades-long civil strife. They commended the authorities for the generally good macroeconomic performance of the past few years, which reflects prudent fiscal policy as well as favorable external developments. However, they expressed concern that growth has been narrowly based and poverty has not fallen. Accordingly, Directors emphasized the importance of increasing the pace of reforms, and in particular, addressing governance issues, strengthening the legal and judicial system, and nurturing the agricultural sector. They saw these reforms as essential to encouraging investment, growth, and product diversification. They noted that these measures are all the more important in view of the difficulties Cambodia will face in competing in the garment sector after the elimination of the quota system in early 2005.

Directors welcomed the government's continued commitment to poverty reduction as discussed in the first annual progress report of Cambodia's National Poverty Reduction Strategy (NPRS) Paper. They noted with concern that the reform process has been largely put 
on hold during the post-election political impasse and looked forward to rapid progress to achieve the poverty reduction targets established in the NPRS. They cautioned that further delays could reduce donor assistance and threaten fiscal sustainability. They acknowledged that these reforms will require strong political commitments, and in this regard, welcomed the new government's emphasis on these priorities.

Directors urged the government to attach high priority to agricultural and land reform, which they saw as an effective and direct way to address poverty since most of the poor live in rural areas. To improve land use, they advised auditing already-awarded economic concessions, reviewing the transfers of ownership of de-mined and de-forested land, and speeding up land registration for rural farmers. Policies should be implemented to enhance land tenure security and eradicate illegal settlement and grubbing. They encouraged the government to review, together with donors, the current allocation of foreign aid flows, with a view to refocusing it on agricultural development.

Directors observed that Cambodia needs to intensify efforts to attract foreign investment in order to promote diversified growth. While recognizing that significantly improving infrastructure and human capital and establishing a sound regulatory environment can only be achieved in the long run, they suggested that there is considerable scope for improving the business climate in the short run by cutting cumbersome red tape and high informal fees, and by allowing greater wage flexibility.

Directors urged the authorities to accelerate judicial reform to address governance problems that are deeply rooted in all aspects of economic activities. They looked forward to the adoption of the Anti-Corruption Law and the Law on the Status of Judges and Prosecutors, which will strengthen the independence of the judiciary, and to the establishment of a commercial court. Directors welcomed ratification by the National Assembly of Cambodia's entry to the WTO, and the impetus it will give to putting in place a legal framework for a market economy.

Directors emphasized the critical importance of strengthening revenue mobilization in order to attain the government's medium-term fiscal objectives. They urged the government to take additional tax policy measures and further strengthen tax and customs administration to meet the 2004 revenue and medium-term NPRS targets. In this respect, they noted the crucial importance of broadening the tax base by reducing exemptions, and to strengthening enforcement by computerizing the revenue departments and passing the Law on Customs. They noted the potential contribution of good management of natural resources to the revenue base.

Directors agreed that another key component of fiscal reform is improving public expenditure management. They pointed to the establishment of the Ministry of Economy and Finance reform committee as promoting ownership and internalization of technical assistance. They recommended that the National Audit Authority audit the operations of existing fiscally-important contract holders to verify compliance with the terms of the contracts, and making the audit reports public. 
Directors recommended overhauling the civil service and its wage structure to improve government effectiveness. They called for an early completion of the ongoing but substantially delayed studies on civil service reform as a critical step in preparing a comprehensive reform strategy, in consultation with the World Bank.

Most Directors supported the National Bank of Cambodia's policy of intervening in the foreign exchange market to stabilize excessive fluctuations of the exchange rate. In view of the highly dollarized economy, they noted the limitation of exchange rate policy in affecting competitiveness. They therefore suggested maintaining a broadly stable exchange rate relative to the U.S. dollar, barring fundamental changes in market conditions.

Directors agreed that Cambodia would benefit from de-dollarizing the economy over time, and saw greater use of the national currency as facilitating the reorientation of monetary policy to controlling inflation and the use of indirect monetary control instruments. They suggested that de-dollarization initiatives, such as requiring that all government transactions be conducted in domestic currency and issuing a larger denomination note, should be considered, but cautioned that forceful and abrupt administrative de-dollarization measures or political uncertainty could immediately translate into capital flight.

Directors highlighted the key importance of further strengthening financial supervision. They welcomed the progress made in this area and looked forward to early passage of laws to facilitate sound intermediation of banks, reduce payment system risks, and ensure a legal basis for collateral-based lending, among other initiatives. Directors welcomed progress made in the preparation of a new comprehensive anti-money laundering law and looked forward to its adoption.

Directors encouraged the authorities to continue to pursue prudent debt management policies in order to ensure fiscal sustainability. They welcomed continued dialogue with the United States and the Russian Federation to seek ways to complete debt rescheduling negotiations, and looked forward to their early completion. The importance of resolving these negotiations satisfactorily to ensuring continued access to Fund financing was noted.

Directors welcomed the opportunity to review Cambodia's performance under Fund arrangements since the early 1990s, and agreed that Fund involvement has been effective in maintaining macroeconomic stability. They noted, however, that despite important progress achieved in many areas, poverty remains pervasive and governance problems widespread. Looking ahead, Directors considered that a new arrangement with the Fund would help strengthen Cambodia's official international reserve position, contain possible adverse effects from the forthcoming elimination of the garment quota, underpin a framework for donor coordination, and encourage domestic reform efforts. Directors stressed that sound policies by the authorities would also be needed to catalyze international support for Cambodia's poverty reduction strategy.

In view of substantial weaknesses in Cambodia's statistical framework, Directors welcomed the work to upgrade it, and saw, in the coming years, a need to rely more on domestic 
resources and training to strengthen technical capacities. They observed that if donor financing is lacking, this may require a shift of resources within the current budget.

Public Information Notices (PINs) form part of the IMF's efforts to promote transparency of the IMF's views and analysis of economic developments and policies. With the consent of the country (or countries) concerned, PINs are issued after Executive Board discussions of Article IV consultations with member countries, of its surveillance of developments at the regional level, of post-program monitoring, and of ex post assessments of member countries with longer-term program engagements. PINs are also issued after Executive Board discussions of general policy matters, unless otherwise decided by the Executive Board in a particular case. 
Cambodia: Selected Economic Indicators, 1999-2003

$\begin{array}{lllll}1999 & 2000 & 2001 & 2002 & 2003\end{array}$

\section{Output and prices}

Real GDP

GDP deflator

CPI Inflation (end of period)

\section{Money and credit}

Broad money

Net credit to the government $1 /$

Private sector credit

\section{Government budget}

Total Revenue

Expenditure

Of which: current expenditure

Current budget balance

Overall budget balance

Overall budget balance (incl. grants)

\section{External sector}

Current account (excl. official transfers)

(in percent of GDP)

Exports 2/

Imports 2/

Gross official reserves

(in months of imports of goods and services)

Public external debt 3/

(in percent of GDP)

Exchange rate (riels per dollar; end of period)
(Annual percent change)

$\begin{array}{rrrrr}10.8 & 7.0 & 5.7 & 5.5 & 5.2 \\ 2.1 & -1.7 & -0.3 & 2.1 & 1.6 \\ -0.5 & -0.8 & 0.7 & 3.7 & 0.5\end{array}$

17.3

26.9

20.4

31.1

15.3

$-6.1$

$-6.9$

$-4.3$

$-2.0$

$-0.3$

16.6

17.7

4.2

13.1

26.2

(In percent of GDP)

$\begin{array}{rrrrr}10.2 & 10.4 & 10.7 & 11.2 & 10.4 \\ 14.1 & 15.3 & 16.3 & 17.8 & 17.4 \\ 8.5 & 8.9 & 9.6 & 10.1 & 11.0 \\ 1.6 & 1.4 & 1.1 & 1.2 & -0.6 \\ -3.9 & -4.9 & -5.5 & -6.7 & -7.0 \\ -1.3 & -2.1 & -2.8 & -3.8 & -4.5\end{array}$

(In millions of U.S. dollars; unless otherwise indicated)

Sources: Data provided by the Cambodian authorities; and IMF staff estimates and projections.

1/ Contributions to 12-month percent change of broad money.

2/ Excludes re-exports.

3/ Includes debt owned to the former Council of Mutual Economic Assistance. 
September 22, 2004

\section{IMF Executive Board Reviews Progress Report on Cambodia's Poverty Reduction Strategy Paper}

The Executive Board of the International Monetary Fund (IMF) on September 13, 2004 reviewed the Annual Progress Report on Cambodia's National Poverty Reduction Strategy (NPRS) and welcomed Cambodia's NPRS.

At the conclusion of the Executive Board's discussion based on the Joint Staff Assessment of Cambodia's Annual Progress Report, which was prepared jointly by the staffs of the IMF and the World Bank, Agustín Carstens, Deputy Managing Director and Acting Chair, stated:

"Cambodia has come a long way in rebuilding its economy from the ruins of the decades-long civil strife. Macroeconomic performance of the past few years reflects prudent fiscal policy as well as favorable external developments. However, growth has been narrowly based and poverty has not fallen. It is therefore important to press ahead with efforts to broaden the base of economic activity and reduce poverty by increasing the pace of reforms, and in particular, nurturing the agricultural sector, and strengthening the legal and judicial system. These measures are all the more important in view of the difficulties Cambodia will face in competing in the garment sector after the elimination of the quota system in early 2005.

"The government is committed to poverty reduction as discussed in the first annual progress report of Cambodia's National Poverty Reduction Strategy (NPRS) Paper, which provides a sound basis for continued access to Fund concessional financial assistance. To achieve this goal, Cambodia needs to intensify efforts to attract foreign investment in order to promote diversified growth. There is considerable scope for improving the business climate in the short run by cutting cumbersome red tape and high informal fees, and by allowing greater wage flexibility.

"The authorities also need to accelerate judicial reform to address governance problems that are deeply rooted in all aspects of economic activities. The ratification by the National Assembly of Cambodia's entry to the WTO is welcome.

"Strengthening revenue mobilization is critical in order to attain the government's medium-term fiscal objectives. The government will need to take additional tax policy measures and strengthen tax and customs administration to meet the 2004 revenue and medium-term NPRS targets. 
Another key component of fiscal reform is improving public expenditure management and reforming the civil service.

"The opportunity to review Cambodia's performance under Fund arrangements since the early 1990s is welcome and demonstrates that Fund involvement has been effective in helping maintain macroeconomic stability. Nonetheless, poverty remains pervasive and governance problems widespread. A new arrangement with the Fund could help strengthen Cambodia's economy, underpin a framework for donor coordination, and encourage domestic reform efforts," Mr. Carstens said. 


\section{Statement by Ismail Bin Alowi, Alternate Executive Director for Cambodia and Tirta Segara, Advisor to Executive Director \\ September 13, 2004}

\section{Introduction}

On behalf of our Cambodian authorities, we would like to express their appreciation to the staff, management and the Executive Board as well as other development partners and the donor community for their advice and continued support. The authorities would also like to express their appreciation for a balanced Staff Report for the 2004 Article IV, and constructive advice. On the Ex Post Assessment of Longer-Term Program Engagement paper, the authorities find the paper useful and provides a balanced and comprehensive review of the Cambodia's achievement during the Fund supported programs.

Continued sound macroeconomic policies, supported by financial and technical assistance from the international community have contributed to macroeconomic stability and important progress in building central institutions of macroeconomic management, restructuring the financial sector and integrating Cambodia into the world economy. Despite these improvements, Cambodia's economy still faces several challenges. Poverty remains pervasive as the economic growth remains narrowly based and volatile. Growth in the agricultural sector has been slow. While some progress has been made in structural reforms, structural weaknesses remain. In view of these challenges, the Cambodian authorities would like to reiterate their continued commitment to sound macroeconomic management and reform agenda, consistent with the objective of NPRS and SEDP.

The authorities strongly believe that Cambodia has no other better choice than strongly implementing comprehensive reform. The formation of new administration in July 2004 within a peaceful and stable environment has provided the authorities with a renewed opportunity to push forward their reform agenda in order to achieve the National Poverty Reduction Strategy (NPRS) targets, aiming at promoting strong growth and reducing poverty. In this regard, the new administration has announced and outlined its "Rectangular Strategy" as an effective policy tool for the Royal Government to implement the NPRS. The Rectangular Strategy focuses on (i) the promotion of economic growth (ii) the generation of employment (iii) the implementation of the Governance Action Plan and thereby ensuring equity and social justice and (iv) enhancing efficiency and effectiveness of the Royal Government in implementing the reform programs.

\section{Recent Economic Developments and Prospects for 2004}

A combination of prudent macroeconomic policies and favorable external developments contributed to Cambodia's favorable macroeconomic performance in the past few years. During 1999 - 2002 real GDP grew by 6.7 percent per annum. The Cambodian authorities are aware that such a robust growth was narrowly based, driven mainly by the garments, tourism, and construction sectors. In 2003, growth remained strong at 5.2\%, 
reflecting a strong rebound in agricultural production, thanks to favorable weather condition. The impacts of SARS on tourism was less severe than expected, with a sharp rebound in tourist arrivals toward the end of 2003. For 2004, the authorities are more sanguine than staff on economic prospects in view of strong recovery in tourism and strong performance in the garment industry. The agricultural sector is also expected to record a strong growth as the authorities believe that the Avian flu has smaller impact than projected by staff.

The inflation rates during the past few years remained low, reflecting continued prudent monetary and fiscal policy. In 2003, based on 12-month average, the inflation rate was only 1.2 percent. Meanwhile, the year-on-year inflation rate in December 2003 was only 0.5 percent. The absence of supply shock combined with cheaper imports from neighboring countries have also contributed to the subdued inflation. For 2004, inflation is expected to rise slightly in line with price developments in trading partners countries. External position has improved with gross official reserves increasing steadily to US\$ 737 million at the end of 2003, sufficient to cover 3 months of imports of goods and services.

\section{Fiscal Policy}

Recognizing the importance of and the key role played by fiscal policy in achieving macroeconomic stability in a highly dollarized economy, the Cambodian authorities have continued to pursue a prudent fiscal policy and to implement the necessary fiscal reforms to ensure a favorable macroeconomic and financial environment as a foundation for sustainable growth, including the adequacy of the budget to meet the NPRS targets. During the past few years, several structural measures have been implemented to strengthen tax and customs administration, including broadening the tax base and preventing leakages. As a result, the overall fiscal performance was significantly improved as government revenue increased steadily to 11.2 percent of GDP in 2002. While the revenue collection in 2003 declined, partly reflecting delayed payment of taxes, the revenue target for fiscal year 2004 has been set at 11.9 percent of GDP. In this respect, the current budget surplus is expected to increase to 1.2 percent of GDP, compared with a deficit of 0.6 percent of GDP in 2003 . To meet the revenue target for 2004, the government will continue to implement vigorously fiscal measures, focusing in particular on the collection of tax arrears, further the improvement of tax and customs administration. In addition, the authorities will be more cautious in awarding government contracts to private sector.

On the expenditure side, the government has exercised prudence, putting in place significant expenditure restraints in order to provide scope for priority spending and budget reallocation. Budget management had been streamlined through reallocation of spending to the social and economic sector. In line with its commitment to a pro-poor fiscal policy, the Cambodian government carried out military demobilization to divert more resources from defense and security to the social sector. In this connection, defense and security spending is expected to decline from 3.8 percent of GDP in 1999 to 2.4 percent of GDP in 2004, while social sector spending is budgeted to increase from 1.8 percent to 3.8 percent of GDP over the same period. Administrative procedures and public sector governance would also be enhanced to ensure that social sector spending targets are achieved. Moreover, to further 
strengthen budget management, the government accounts have been centralized at the National Treasury.

With regard to the external debt, the Cambodian authorities have continued their efforts in seeking resolution to its outstanding debts with bilateral creditors, in particular, with the United States and the Russian Federation

\section{Monetary and Exchange Rate Policy and Financial Sector Reform}

Monetary restraint and the NBC's foreign exchange intervention policy, supported by prudent fiscal policy and lower imported inflation has contributed to lower inflation in 2003. The CPI inflation declined from $3.7 \%$ at end -2002 to $0.5 \%$ at end -2003 . As a matter of policy, the NBC will intervene in the foreign exchange market to stabilize excessive fluctuations of the exchange rate. The objective of the policy is to stabilize riel inflation at a low level by maintaining a broadly stable exchange rate. In a highly dollarized economy, exchange rate policy has limited effects on competitiveness and limited role as a shock absorber in the short-term. Nevertheless, an exchange rate adjustment will be considered, if there are significant fundamental changes in underlying market conditions. Going forward, the NBC is committed to further improve its monetary policy instruments. Therefore, the cooperation and assistance from the Fund is warranted.

The authorities acknowledge that de-dollarization would benefit the Cambodia economy in the long run. Full de-dollarization would allow monetary policy to be conducted effectively and independently and to be used as counter cyclical tool. In this regard, the authorities are taking steps to promote de-dollarization. In particular, the authorities will consider to require all government domestic transactions be paid in the local currency. Demand for local currency, riel, is growing steadily mainly in the rural area and for government transaction purposes. Riel in circulation rose from almost 2.5 percent of GDP in 1994 to over 5 percent in 2003.

On the financial sector reform, the reform has been progressing well. The successful bank restructuring during 2000 - 02 has strengthened the soundness of the banking system. The banking system is now well capitalized with capital adequacy ratios reaching $36 \%$ as at end-July 2004 and banks are subject to a comprehensive regulatory and supervisory regime. Reform were successfully in enhancing public confidence which were reflected in the upward trend in deposits and credits. Nevertheless, the NBC is well aware that financial intermediation remained limited, especially in the rural area and NBC supervisory capacity needs to be strengthened. In this regard, several prakas have been issued recently on Prepaid Payments on Rentals and Leases, Requirement in compliance with Fact and Substance, and Payments of Dividends in advance to contain any potential access to banks' assets. The authorities are taking steps to ensure early passage of the Negotiable Instruments and Payment Transactions Law, the Secured Transaction Law, the Insolvency Law and the Securities and Exchange Law. A new chart of accounts has been introduced and a full compliance by banks is expected by end of 2004 . The NCB is also working towards reducing 
lending rates in rural areas through increased competition among lending institutions and promoting microfinance in the rural area.

\section{Governance and Other Structural Reforms}

The authorities recognize that strengthening structural reform efforts in all sectors particularly in the areas of governance, civil service, agricultural sector will be key to sustaining growth and competitiveness as well as reducing poverty. For Cambodia, good governance is a backbone and prerequisite for sustainable socio-economic development and ensuring social justice. Therefore, the authorities remain determine in promoting good governance through effective implementation of the Governance Action Plan (GAP) as a roadmap to guide a comprehensive reform of governance in Cambodia. The GAP covers four crosscutting areas of reforms: (i) combating corruption, (ii) judicial and legal reforms, (iii) public administration reform, and (iv) demobilization of armed forces and natural resources management.

In fighting corruption, the Royal Government of Cambodia remains committed to the adoption of Anti-corruption Law which has been submitted to the Parliament. This will be accompanied by the establishment of an independent body to fight corruption - the Supreme Council Against Corruption - and mechanism to strengthen the effectiveness of law enforcement. In addition, the government is also committed to continue promoting the effectiveness, transparency and accountability in the management of public finances, especially through the strengthening of audit process and public procurement. In this context, the authorities introduced the Law on Audit and established the National Audit Authority (NAA) in 2000, and expressed their intention to ratify the new United Nations anticorruption convention.

The Cambodian authorities share the staff's concern on the urgency of the judicial reform to address governance problems. As has also been identified by the Investment Climate Survey, judicial reform is a critical factor to the establishment of favorable investment climate, based on the rule of law. Over the past few years, various laws, from the laws related to human rights, laws on investment, trade and commerce, to laws to support natural resources management, have been enacted. To improve the quality of judges and prosecutors, the government established the Royal School of Judges and Prosecutors in 2002. In addition, beginning in 2003, remuneration for judges and prosecutors was increased.

The authorities agree with staff that the limited human and financial resources are among major challenges faced by Cambodia in this area, and hence, external assistance will remain be warranted. Nonetheless, the Royal Government of Cambodia remain strongly committed to continue the legal and judicial reforms to ensure the independence of the court system through the implementation of key policies and strategies developed by the Council of Legal and Judicial Reform. In this respect, the government will prepare an action plan focusing on the finalization and submission of draft basic laws to the National Assembly. In addition, to realize Cambodia's commitment under the WTO, various laws related to commercial transactions will go through the legislative process. 
With regard to the administrative reforms, the government has adopted the National Program for Administrative Reform to transform the administration and civil service into an effective organization. The provision of public services will be facilitated and simplified through the elimination of overlapping work, streamlining bureaucracy, and by implementing decentralization. These procedures will be gradually computerized to improve transparency and reduce corruption. Special attention will be given to the management of civil servants to move the public administration closer to the people. The Cambodian authorities also share the staff's view that the low quality of public services is largely attributed to the low wages in the civil service, which is approximately only one-third of the average wage of private sector employees in the formal sector. In light of this, in the recent years the authorities increased salaries for civil servants commensurably with their skills, experience and responsibility, especially for teachers and health workers.

Given the significant dependency of the poor to the agricultural sector, the authorities fully agree that urgent reform in this sector is essential to achieve the NPRS objective of reducing poverty. Therefore, addressing key impediments to agricultural growth is one of the government's reform agenda. Recognizing that the improvement of access to arable land may take longer time, in the short-term, the authorities will shift its direction from "expansionary" or "extensive" agriculture to "deepening" or "intensive" agriculture, by increasing the yields of the existing land. This strategy will be supported by more extensive agricultural research, market developments, distributions of seeds and fertilizer, as well as supply of rural credit. The authorities will continue to enhance marketing channels and institutionalize micro-finance activities in rural areas. On the land reform, the government will continue to implement the Law on Land Management and land policy to strengthen an equitable and efficient system of land management, distribution and utilization. This will include land restoration and distribution, land tenure security, eradication of illegal settlements and land grabbing, and control of land ownership concentration for speculative purposes.

\section{Measures to Improve Business Climate}

As an engine of growth for Cambodia, a healthy private sector is key to promoting economic development. Therefore, the government will continue to promote good governance, strengthen the legal frameworks, regulations and institutional capacity to facilitate business and private investment activities. For this purpose, the government recently established the Steering Committee for Private Sector Development, supported by three sub committees which are already operational. Specific measures to facilitate business have been set out, aiming at reducing cost and time imposed on companies on their registration and export-import operation. Beginning in September this year, the cost of registration will be reduced from USD615 to USD177, while the time spent on paperwork will also be reduced from 30 to 10.5 days. In addition, the government also intend to improve the effectiveness of government-private sector forum. 


\section{Removal of Quotas on Textiles and Clothing Exports}

The authorities are aware that despite the continued robust production and investment in the garment industry in Cambodia, the phasing out of Multi-Fiber Agreement (MFA) will affect the Cambodia's garment industry. While it is not easy to predict the size of potential impact on Cambodia's market share, the authorities are more sanguine than staff in estimating the decline in the value of garment exports and its impact on the GDP growth. Over the last 19 months, 22 companies have expanded their production capacities, reflecting their optimistic expectations on their operations in Cambodia. Nevertheless, the authorities agree with staff that to dampen the impact from the expected decline in garment exports, the government need to redouble its effort in improving competitiveness. In this respect, the authorities already took several measures to improve competitiveness, by reducing operating costs, particularly labor and administrative costs. In addition, the authorities are in the process of seeking the preferential duty treatment from the US government in the same terms as applied to the African poorest countries under the African Growth and Opportunity Act adopted by the US Congress. Cambodia's good record of adherence to core labor standards should be a good incentive.

\section{Ex Post Assessment of Longer -Term Program Engagement}

The authorities appreciate the Ex Post Assessment (EPA), which provide a useful review and foundation for future reform plans. The authorities agree with the main finding of the report that, despite favorable macroeconomics developments and important progress achieved in many areas under previous Fund - supported program, poverty remains pervasive and strengthening of governance is crucial. With respect to poverty, while the authorities agree that widespread poverty is a serious problem, they caution against unqualified comparison of indicators across countries, given the significant differences in data quality and methodologies used in calculation. Regarding the governance, the authorities are fully aware that much remain need to be done, and they have reaffirmed their strong commitment to address it vigorously. On the external financial assistance, the authorities note that aid in the form of technical cooperation is adequate and donors would have helped promote greater ownership by using more local staff. In this respect, the authorities would like to underscore the importance of training local trainers. The Cambodian authorities also agree with the key elements of the strategy proposed in the EPA for future engagement with the Fund.

\section{Conclusion}

In conclusion, with continuous support from the international community and the authorities' strong efforts to implement structural reforms and pursue a sound macroeconomic policies, Cambodia has made considerable progress under the Fundsupported program despite its prevailing capacity constraints and unfavorable external factors. The authorities have renewed their commitment to move forward to strengthen governance and improve institutional capacity. They are fully aware that the absence of these measures could undermine the investment and business climate in Cambodia. Given the 
limited resources, the success of this economic reform will depend on continued support from the international community. In this regard, the authorities continue to count on the strong support from the international community, including the Fund. In particular, they request the Fund to continue to provide policy advice, more focused technical assistance, and financial support. Therefore, they would like to start discussion on an economic program to be supported by a PRGF program. In addition to help strengthen Cambodia's official reserves position and contain possible adverse impact from the phasing out of the garment quota, this arrangement would help underpin a framework for donor coordination and encourage domestic reform efforts within the government. 